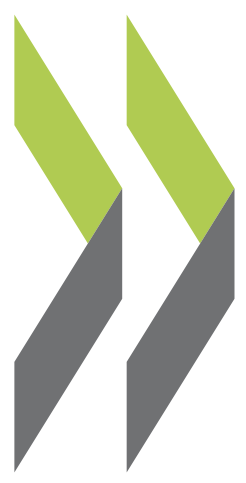

OECD Economics Department Working Papers No. 1129

\title{
An Update of the OECD International Trade Equations
}

Myriam Morin, Cyrille Schwellnus 
Organisation de Coopération et de Développement Économiques

Organisation for Economic Co-operation and Development

23-Jun-2014

ECONOMICS DEPARTMENT

English - Or. English

\section{AN UPDATE OF THE OECD INTERNATIONAL TRADE EQUATIONS}

ECONOMICS DEPARTMENT WORKING PAPERS No. 1129

\section{By Myriam Morin and Cyrille Schwellnus}

OECD Working Papers should not be reported as representing the official views of the OECD or of its member countries. The opinions expressed and arguments employed are those of the author(s).

Authorised for publication by Jean-Luc Schneider, Deputy Director, Policy Studies Branch, Economics Department.

All Economics Department Working Papers are available through OECD's internet website at www.oecd.org/eco/workingpapers

Complete document available on OLIS in its original format

This document and any map included herein are without prejudice to the status of or sovereignty over any territory, to the delimitation of international frontiers and boundaries and to the name of any territory, city or area. 
OECD Working Papers should not be reported as representing the official views of the OECD or of its member countries. The opinions expressed and arguments employed are those of the author(s).

Working Papers describe preliminary results or research in progress by the author(s) and are published to stimulate discussion on a broad range of issues on which the OECD works.

Comments on Working Papers are welcomed, and may be sent to OECD Economics Department, 2 rue André-Pascal, 75775 Paris Cedex 16, France, or by e-mail to eco.contact@oecd.org

This document and any map included herein are without prejudice to the status of or sovereignty over any territory, to the delimitation of international frontiers and boundaries and to the name of any territory, city or area.

The statistical data for Israel are supplied by and under the responsibility of the relevant Israeli authorities. The use of such data by the OECD is without prejudice to the status of the Golan Heights, East Jerusalem and Israeli settlements in the West Bank under the terms of international law.

\section{(c) OECD (2014)}

You can copy, download or print OECD content for your own use, and you can include excerpts from OECD publications, databases and multimedia products in your own documents, presentations, blogs, websites and teaching materials, provided that suitable acknowledgment of OECD as source and copyright owner is given. All requests for commercial use and translation rights should be submitted to rights@oecd.org 


\section{ABSTRACT/RÉSUMÉ}

\section{An update of the OECD international trade equations}

This paper provides a detailed description of recent research to re-estimate and re-specify the international trade volume and price equations that are used in the OECD Economics Department to analyse and project international trade developments. The set of countries covered by the estimations has been significantly enlarged, with estimates of the factors affecting export performance, import penetration and trade prices presented for 41 countries, including countries that have recently joined the OECD (Chile, Estonia, Israel and Slovenia) and major emerging countries (Argentina, Brazil, China, India, Indonesia, Russia and South Africa). Reflecting the heterogeneity of countries included in the estimations, procedures for grouping them have been modified to allow for country specifics as much as possible. Structural breaks over the estimation period - which now typically covers the mid-1980s to 2012 and includes the global trade collapse of 2009 - are dealt with by the flexible modelling of deterministic trends, including the allowance for several rather than single trend reversals.

JEL classification codes: F14; F17

Keywords: Trade, trade elasticities, trade forecasting

$* * * * * * * * * * * * * * * * * * * * * * * * * * * * * * * * * * * * * * *$

\section{Une mise à jour des équations de commerce international de l'OCDE}

Ce document fournit une description détaillée du travail de ré-estimation et re-spécification des équations de volume et de prix du commerce international qui sont utilisées dans le Département des affaires économiques de l'OCDE pour analyser et prévoir l'évolution du commerce international. L'ensemble des pays couverts par les estimations a été considérablement élargi : les estimations des facteurs affectant la performance à l'exportation, la pénétration des importations et les prix du commerce sont présentées pour 41 pays, y compris les pays qui ont récemment adhéré à l'OCDE (Chili, Estonie, Israël et Slovénie) et les grands pays émergents (Argentine, Brésil, Chine, Inde, Indonésie, Russie et Afrique du Sud). Afin de mieux refléter l'hétérogénéité des pays inclus dans les estimations, les procédures de regroupement des pays ont été modifiées pour prendre en compte les spécificités des pays autant que possible. Les ruptures structurelles au cours de la période d'estimation - qui maintenant couvre généralement le milieu des années 1980 jusqu'à 2012 et désormais comprend l'effondrement du commerce mondial de 2009 - sont traitées par la modélisation flexible de tendances déterministes qui permet de multiples points d'inflexion plutôt qu'un point unique d'inversion de tendance.

Codes JEL : F14; F17

Mots Clés : Commerce international, élasticités de commerce, prévisions de commerce 
TABLE OF CONTENTS

AN UPDATE OF THE OECD INTERNATIONAL TRADE EQUATIONS ….............................................. 5

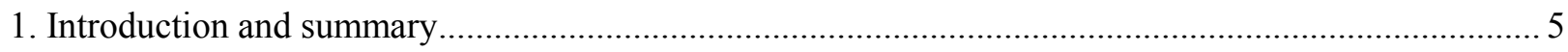

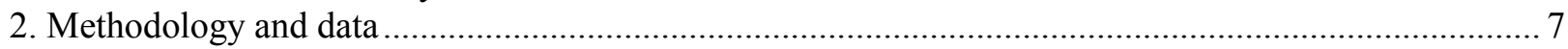

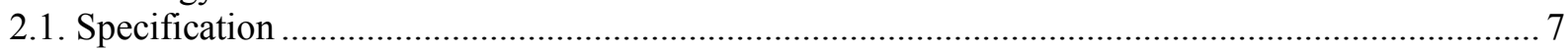

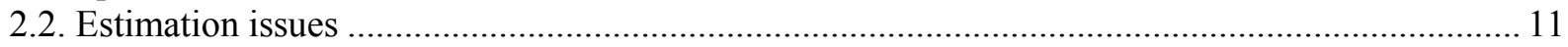

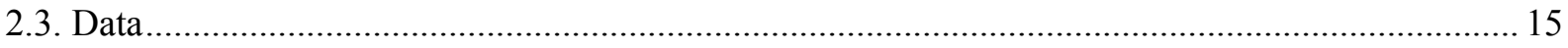

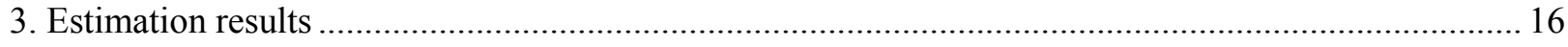

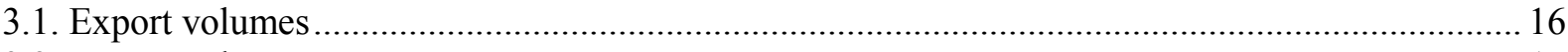

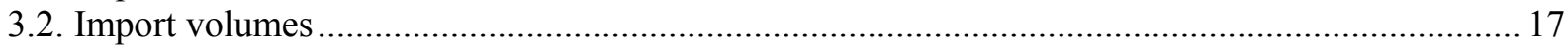

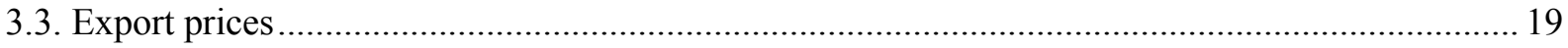

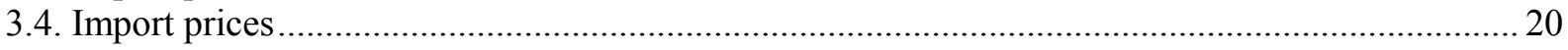

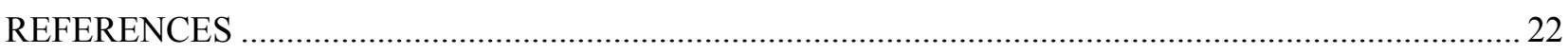

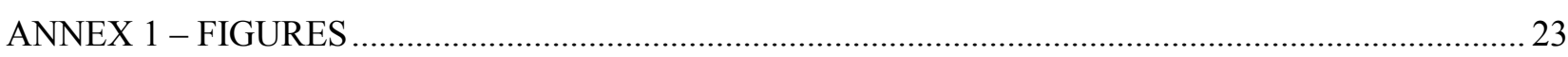

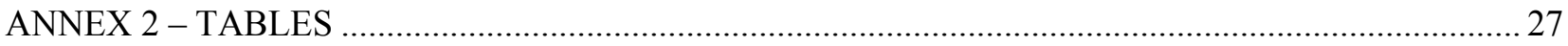

\section{Boxes}

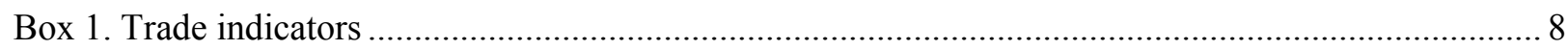


ECO/WKP(2014)25

\title{
AN UPDATE OF THE OECD INTERNATIONAL TRADE EQUATIONS
}

\author{
by \\ Myriam Morin and Cyrille Schwellnus ${ }^{1}$
}

\section{Introduction and summary}

1. This paper describes recent research to re-specify and re-estimate the international trade equations, which link one country's trade volumes and prices to developments in other countries. These equations are used in the OECD Economics Department to monitor the global consistency of the international trade projections in the semi-annual Economic Outlooks. Note that the trade equations presented in this paper do not per se ensure globally balanced trade as the equations cover only a subset of countries, and no global adding-up constraint has been imposed. In forecasting practice, the estimated equations are complemented by a range of additional forecasting tools and judgmental adjustments that ensure that global trade is balanced and consistent with global GDP developments (Guichard and Rusticelli, 2011; Cheung and Guichard, 2009; Brézillon, Guichard and Turner, 2010).

2. The immediate need for updating the international trade equations arose from the incomplete country coverage and the declining accuracy of the previous set of equations. The last estimation (Pain et al., 2005) covered all 30 OECD member countries at that time plus China. Since the earlier estimation was carried out new countries have joined the OECD (Chile, Estonia, Israel and Slovenia). Moreover, some major emerging countries including Brazil, India, Indonesia, Russia and South Africa were covered only as part of broad geographical aggregates. Above all, the worsening fit of the estimated equations suggests that since the last estimations structural changes in world trade may have modified underlying model parameters. In particular, the last estimations were conducted with data ending in 2002, thus only incompletely covering the integration of China and some other large emerging countries into the world trading system and excluding the world trade collapse of 2009.

3. The trade matrix underlying the calculation of the relevant trade aggregates such as export market size or competitors' prices has been updated to reflect trade patterns in 2010. The previous set of estimations used the trade matrix for 2000, thereby systematically underestimating the role of large emerging markets whose share in global trade increased substantially over the past decade (Figures A.1.A.3.). For a number of OECD countries, estimated export market growth over the past decade based on the updated trade matrix was significantly larger than based on the previous trade matrix, as some countries increasingly re-directed exports to dynamic emerging markets. For instance, the cumulated difference in export market growth over 2000-12 based on the updated and the previous trade matrix was around 20 percentage points for Australia and around 10 percentage points for Japan, as both countries increasingly re-directed exports toward China (Figure A.4.). By contrast, cumulated export market growth for a number of Central and Eastern European countries over 2000-12 was significantly lower based on the updated trade matrix than the previous trade matrix, as these countries increasingly re-directed exports toward the

1. Myriam Morin works at the Direction Générale du Trésor and Cyrille Schwellnus works at the OECD Economics Department. The authors would like to thank Jérôme Brézillon, Thomas Chalaux, Peter Jarrett, Urban Sil, Jean-Luc Schneider and Dave Turner for valuable comments and discussions, and Ines Gomez Palacio for her assistance in preparing the document. 
European Union. In some other countries, such as Germany and the United States, the switch to the 2010 matrix does not have an appreciable impact on export market growth over the period 2000-12.

4. The main changes in coverage and structure of the newly estimated trade equations are as follows:

- Equations are estimated for 41 individual countries (all OECD and BRIICS countries as well as Argentina) while the previous estimation covered only 31 individual countries.

- The specification of the non-linear deterministic trends that capture otherwise excluded factors has been modified. Such deterministic trends capture the influence of factors such as shifts in product quality or declines in trade costs, e.g. related to regional trade agreements, on export performance, import penetration and relative trade prices. Whereas the previous estimation specified deterministic trends as combinations of linear and logarithmic functions, this paper specifies them as piece-wise linear functions. This has the advantage of allowing for more than one turning point in the deterministic trend, which is a particularly desirable property, given large structural changes in world trade over the sample period. Moreover, the adopted estimation procedure allows flexible re-estimation of the last deterministic trend based on the equation residuals without re-estimation of all model parameters. This is a major advantage compared to the previous estimation setup, which assumed a gradual phase-out of deterministic trends out of sample but did not allow the adjustment of deterministic trends based on residuals, despite the equations' deteriorating fit over time.

- The procedure for grouping countries has been modified to allow for country specifics as much as possible. The previous set of estimations imposed common coefficients across countries when this was not rejected by the data to enhance estimation efficiency. With quarterly time series now covering 10 additional years, estimation efficiency turned out to be less critical so that short- and long-run dynamics were allowed to vary across countries so long as estimated coefficients satisfied broad priors on sign and statistical significance.

5. The main results of this paper can be summarised as follows:

- Non-linear deterministic trends are crucial in explaining the evolution of trade volumes and prices. In most countries, the long-run equilibrium between trade volumes/prices and explanatory variables includes deterministic trends that change sign once or several times over the sample period. In some countries, deterministic trends contribute significantly to trade volume/price growth at the end of the sample period, requiring careful out-of-sample modelling, particularly to avoid giving undue weight to immediate post-crisis developments.

- In most countries, the contribution of deterministic trends to import and export price growth has been negative over the past two decades. The consistent decline of trade prices relative to economy-wide prices partly reflects the preponderance of manufactures in trade as well as falling trade costs and enhanced competition on world markets.

- The estimated export volume equations imply that although deterministic trends raise export performance in several OECD countries at the end of the sample period (2012) - including Australia and Germany - on average deterministic trends do not contribute to export performance in OECD countries. By contrast, deterministic trends raise export performance by around 2 per cent per year in China, $3 \frac{1}{2}$ per cent in India and $1 \frac{1}{2}$ per cent in Indonesia. 
- Although import content is higher for investment than for private consumption, the impact of fluctuations in investment on import volume growth is typically smaller, which reflects the fact that in most countries the share of investment in total expenditure is only about one third the share of private consumption. The low impact of fluctuations in public consumption on import volume growth reflects public consumption's low import content and its small share in total expenditure.

- Exports can have a large impact on import volume growth in very open economies that are highly integrated into global production chains; for countries such as Ireland, Korea, Luxembourg and Slovakia the elasticity of imports to exports is above 0.5 whereas it is around 0.2 for Brazil, India or the United States. Overall, the cross-country pattern of marginal propensities to import out of exports implied by the estimations is consistent with the pattern of trade in value added (OECDWTO, 2013), in the sense that implied marginal propensities to import are higher for countries with high shares of foreign value added in gross exports.

- In most countries, there is clear evidence for pricing to market, with only partial pass-through of domestic costs to trade prices. Complete pass-through of domestic costs to trade prices occurs only in a handful of countries, including the United States and Japan.

6. The remainder of the paper is structured as follows. Section 2 explains the methodology and data used for estimating equations for export and import volumes as well as prices, with a particular focus on the modelling of deterministic trends and the procedure for grouping countries. Section 3 presents and discusses the main results. The annexes provide details on the estimation results and implications of modelling choices on short-term forecasts.

\section{Methodology and data}

7. This section describes the basic structure of the estimated trade volume and price equations, with a particular focus on a number of estimation issues, such as the modelling of deterministic trends and the grouping of countries.

\subsection{Specification}

8. Trade volume and price equations are specified as error correction models, with as few crosscountry constraints on estimated parameters and error variances as possible. Tests of co-integration for this class of model were based on Banerjee et al. (1998) and generally found statistically valid long-run relationships between the variables. So long as estimated parameters on the included explanatory variables satisfied theory-based priors on sign and statistical significance, e.g. positive signs on the expenditure variables in the volume equations, parameters and error variances were left unconstrained to allow for country specificity as much as possible. This differs from the approach in the previous set of estimations which - reflecting lower estimation efficiency due to a significantly shorter sample - resorted to crosscountry constraints on estimated coefficients and error variances more widely. 
Box 1. Trade indicators

Export market for goods and services, 2005 USD (XMKT)

$$
X M K T_{i}=\left(\sum_{p=1}^{N} \frac{X G S_{i \rightarrow p}}{X G S_{w l d} \rightarrow p} * M G S V D_{p}\right)
$$

where: $X G S_{i \rightarrow p}=$ goods and services export values in 2010 from country $i$ to country $p$

MGSVD $_{p}=$ import volume of country $p$, expressed in 2005 USD

Competitors' price of goods and services exports (PXC)

$P X C_{i}=\left(\sum_{\substack{p=1 \\ p \neq i}}^{N} \frac{X G S_{i \rightarrow p}}{X G S_{\text {ld } \rightarrow p}-X G S_{i \rightarrow p}} * \frac{1}{X G S_{i \rightarrow w l d}} * \sum_{\substack{r=1 \\ r \neq i, p}}^{N} X G S_{r \rightarrow p} * P X G S_{r} * E X H I N\right) * \frac{1}{E X C H I N}$

where: $P X G S_{p}=$ Exports of goods and services, deflator, national accounts basis of country $p$ and

EXCHIN $_{i}=$ Exchange rate, index of USD per local currency unit of country $i$.

Relative price of goods and services exports (RPX)

$R P X G S_{i}=P X G S_{i} / P X C_{i}$

where: $P X G S_{i}$ is the deflator of goods and services exports.

Shadow price of goods and services imports (PMSHX)

$$
\mathrm{PMSH}_{i}=\left(\sum_{p=1}^{N} \frac{X G S_{p \rightarrow i}}{X G S_{\text {wld } \rightarrow i}} * \mathrm{PXGS}_{p} * \mathrm{EXCHIN}_{p}\right) * \frac{1}{\text { EXCHIN }_{i}}
$$

where: $P X G S_{p}=$ Price of exports of goods and services of country $p$ 
Relative price of imports

$R P M G S_{i}=P M G S_{i} / P T D D_{i}$

where: $P M G S_{i}$ is the deflator of goods and services imports.

$P T D D_{i}$ is the total domestic demand deflator.

Note that the dependent variables for import and export prices in the behavioural equations (3) and (4) below exclude commodity prices. For internal consistency, competitors' prices and shadow prices included in these equations were therefore also re-calculated excluding commodity prices.

\section{Export Volumes}

9. The estimated equation for export volumes is given by:

$\Delta \operatorname{lnXGSV} V_{i t}=\alpha_{0 i}+\alpha_{1 i} \cdot \Delta \ln X G S V_{i t-1}+\alpha_{2 i} \cdot \Delta \ln X M K T_{i t}+\alpha_{3 i} \cdot \Delta \ln R P X G S_{i t}+\lambda_{i} \cdot\left(\ln X G S V_{i t-1}-\right.$ $\left.\beta_{1 i} \cdot \ln X M K T_{i t-1}-\beta_{2 i} \cdot \ln R P X G S_{i t-1}+\beta_{3 i} f\left(T R E N D_{t}\right)\right)+\varepsilon_{i t}$

10. Export volumes of goods and services $(X G S V)$ are modelled as functions of external demand addressed to the country under consideration and the export price relative to competitors'. External demand is measured by export market size $(X M K T$, see Box 1), which is basically a market share-weighted sum of partner countries' imports. Relative export prices $(R P X G S)$ are measured as ratios of export price deflators to competitors' prices of goods and services. In addition to these fundamental drivers of export volumes, the equation includes a deterministic trend $f(T R E N D)$, which picks up omitted factors such as the quality of the studied country's export bundle. The appropriate specification of the deterministic trend and the implications for simulation and forecasting are discussed in more detail below.

11. To ensure that long-run changes in market shares are entirely driven by deterministic trends and changes in relative export prices, it is assumed that the long-run elasticity of exports to export market size is unity, i.e. $\beta_{1 i}=1$. This constraint is generally well supported by the data. ${ }^{2}$

\section{Import Volumes}

12. The equation for import volumes has the following form:

$$
\begin{aligned}
& \Delta \operatorname{lnMGSV} V_{i t}=\alpha_{0 i}+\alpha_{1 i} \cdot \Delta \operatorname{lnMGSV} V_{i t-1}+\alpha_{2 i} \cdot \Delta \operatorname{lnCPV} V_{i t}+\alpha_{3 i} \cdot \Delta \operatorname{lnCGV} V_{i t}+\alpha_{4 i} \cdot \Delta \operatorname{lnITISKV} V_{i t}+ \\
& \alpha_{5 i} \cdot \Delta \operatorname{lnXGSV} V_{i t}+\alpha_{6 i} \cdot \Delta \ln R P M G S_{i t}+\lambda_{i} \cdot\left(\ln M G S V_{i t-1}-\beta_{1 i} \cdot \ln C P V_{i t-1}-\beta_{2 i} \cdot \operatorname{lnCGV} V_{i t-1}+\beta_{3 i}\right. \\
& \left.\operatorname{lnITISKV}_{i t-1}+\beta_{4 i} \cdot \ln X G S V_{i t-1}+\beta_{5 i} \cdot R P M G S_{i t-1}+\beta_{6 i} f\left(T R E N D_{t}\right)\right)+\varepsilon_{i t}
\end{aligned}
$$

2. In most countries, the estimated long-run coefficient of export market size is not different from 1 in a statistically significant way. 
13. Import volumes are modelled as functions of domestic expenditure and import prices relative to domestic prices $(R P M G S)$. Following Pain et al. (2005), the empirical model allows for differing marginal import propensities across domestic expenditure categories: private consumption (CPV); public consumption (CGV); fixed investment plus stockbuilding (ITISKV); and exports of goods and services $(X G S V)$. For China, disaggregated domestic expenditure components at the quarterly frequency are not available, so the import volume equation was estimated distinguishing only between total domestic expenditure and exports.

14. The empirical model imposes a specific structure on import propensities based on available evidence from input-output tables. The empirical evidence in Bussière et al. (2013) suggests that across countries on average the import content of investment and exports is typically higher than that of private consumption, while the import content of public consumption is lower than for all other expenditure categories. The empirical model estimated in this paper imposes a specific structure of import propensities, with country-specific constraints on import propensities based on the import content data reported in Bussière et al. (2013). For most countries, these constraints imply import propensities of investment and exports of around $1 \frac{1}{2}$ times private consumption which is in turn $2 \frac{1}{2}$ times that of public consumption. ${ }^{3}$

15. No constraint that disaggregated expenditure parameters sum to unity was imposed, as this constraint was rejected for most countries in the sample. This implies that import penetration (the ratio of imports to total expenditure) can increase even in the long run - despite the absence of deterministic trends or changes in relative import prices - if the sum of disaggregated expenditure elasticities exceeds unity. In practical terms, expenditure elasticities around 1.5 track the gradual increases in import penetration ratios observed in most countries over the past two decades remarkably well. ${ }^{4}$

\section{Export Prices}

16. The equation for export prices is given by:

$$
\begin{aligned}
& \Delta \ln P X G S X_{i t}=\alpha_{0 i}+\alpha_{1 i} \cdot \Delta \ln P X G S X_{i t-1}+\alpha_{2 i} \cdot \Delta \ln P X C X_{i t}+\alpha_{3 i} \cdot \Delta \ln P T D D_{i t}+\alpha_{4 i} \cdot \\
& \Delta \ln E X C H_{i t}+\lambda_{i} \cdot\left(\operatorname{lnPXGSX} X_{i t-1}-\beta_{i 1} \cdot \ln P X C X_{i t-1}-\beta_{i 2} \cdot \ln P T D D_{i t-1}+\beta_{i 4} \cdot f\left(\text { TREND }_{t}\right)\right)+ \\
& \varepsilon_{i t}
\end{aligned}
$$

17. Export prices corrected for commodity prices $(P X G S X)$ are modelled as depending on the domestic demand deflator $(P T D D)$, which proxies marginal costs, and competitors' prices of noncommodity exports $(P X C X)$, which proxies competitive pressure. Additionally, the empirical model includes the bilateral USD exchange rate ( $E X C H$, USD per unit of domestic currency), which allows a test of whether export prices in domestic currency initially respond differently to changes in the nominal exchange rate and to changes in competitors' prices in US dollar terms. ${ }^{5}$

3. Cluster dissimilarity analysis on the import content data reported in Bussière et al. (2013) suggests forming four country groups for the constraints on marginal import propensities that are reported in Annex Table A.18.

4. Further note that constraining the long-term elasticity of export market size to 1 in the export volume equations while allowing for expenditure elasticities above 1 in the import volume equations does not imply the violation of the global adding up constraint as export market size is computed as the weighted sum of trading partners' imports.

5. Noting that all prices in Equation (3) are expressed in domestic currency, $\alpha_{2 i} \cdot \Delta \ln P X C X_{i t}+\alpha_{4 i} \cdot \Delta \ln E X C H_{i t}$ can be rewritten as $\alpha_{2 i} \cdot \Delta \ln P X C X_{i t}^{U S D}+\left(\propto_{4 i}-\propto_{2 i}\right) \cdot \Delta \ln E X C H_{i t}$. This implies that if $\propto_{4 i}=0$, then the initial response of export prices in domestic currency to a nominal exchange rate appreciation is equal in 
18. Long-run price homogeneity is imposed, i.e. $\beta_{i 1}+\beta_{i 2}=1$, which ensures that in the long run export prices cannot diverge from a weighted sum of foreign and domestic prices. In this empirical framework, in the long run, export prices reflect a trade-off between pricing fully to market $\left(\beta_{i l}=1\right)$ and pricing to domestic costs $\left(\beta_{i 2}=1\right)$. In the case of pricing fully to domestic costs, long-run price homogeneity ensures that, in the absence of deterministic trends, the export price relative to the domestic demand deflator is constant in the long run. Long-run trends in export prices, such as falls relative to aggregate prices of goods and services, are captured by the TREND variable in this setup.

\section{Import Prices}

19. The equation for import prices takes a similar form:

$$
\begin{aligned}
& \Delta \operatorname{lnPMGSX} X_{i t}=\alpha_{0 i}+\alpha_{1 i} \cdot \Delta \operatorname{lnPMGSX} X_{i t-1}+\alpha_{2 i} \cdot \Delta \ln P M S H X_{i t}+\alpha_{3 i} \cdot \Delta \operatorname{lnPTDD} D_{i t}+\alpha_{4 i} \cdot \\
& \Delta \operatorname{lnEXCH} H_{i t}+\lambda_{i} \cdot\left(\ln P M G S X_{i t-1}-\beta_{i 1} \cdot \ln P M S H X_{i t-1}-\beta_{i 2} \cdot \ln P T D D_{i t-1}+\beta_{i 4} \cdot\right. \\
& \left.f\left(T_{R E N D_{t}}\right)\right)+\varepsilon_{i t}
\end{aligned}
$$

20. Commodity price-corrected import prices are modelled as depending on the "shadow price" of goods and services imports $(P M S H X)$, which is calculated as the trade-weighted sum of export prices in trading partners and which proxies costs abroad, and the total domestic demand deflator (PTDD), which proxies competitive pressure from domestically produced goods and services. In the case of full pass through of foreign export price changes to import prices $\beta_{i 1}=1$, whereas $\beta_{i 2}=1$ in the case of full pricing to market behaviour of foreign exporters. The nominal exchange rate $(E X C H)$ is added to test for differences in the initial response of import prices to export prices in trading partners in US dollars and changes in the nominal exchange, with an analogous interpretation of $\alpha_{4 i}$ as in the import price equation. Long-run price homogeneity $\left(\beta_{i 1}+\beta_{i 2}=1\right)$ is imposed to ensure that in the long run import prices cannot diverge from a combination of domestic and foreign prices, with the deterministic TREND term picking up long-term trends in import prices.

\subsection{Estimation issues}

21. The estimation and simulation of the equations described above needs to resolve a number of practical issues, in particular the appropriate specification of deterministic trends and the grouping of countries.

\section{Deterministic trends}

22. Trade volumes and prices are in part determined by factors that are omitted from the equations described above. For instance, increases in the quality of exported goods and services or declines in trade costs, e.g. related to trade agreements such as NAFTA or the European Union, may raise export volumes and reduce export prices at given export market size. Such factors are picked up by the deterministic $f(T R E N D)$ terms in the equations. In most countries, these deterministic trends are not linear over the entire

magnitude but of the opposite sign as the initial response to the equivalent increase in competitors' prices in US dollars. If $\propto_{4 i}>0$, then the initial response of domestic-currency export prices to a nominal exchange rate appreciation is smaller in absolute terms than to a change in competitors' prices in USD, whereas it is larger for $\propto_{4 i}<0$. 
sample period, with periods of trend increases frequently followed by periods of trend decreases. In contrast to Pain et al. (2005) who chose to model such non-linear trends as logarithmic functions, this paper models deterministic trends in the above equations as piecewise linear functions. Given the significantly longer sample period than in the previous set of estimations and large structural changes in international trade over the period 1990-2012, this has the distinct advantage of allowing for more than one turning point in deterministic trends. For instance, the export volume equation for Australia suggests two turning points of the deterministic trend, one in the late 1980s and another just before the global crisis of 2008-09 (Figure 1).

Figure 1. Two turning points in the deterministic trend in the Australian export volume equation

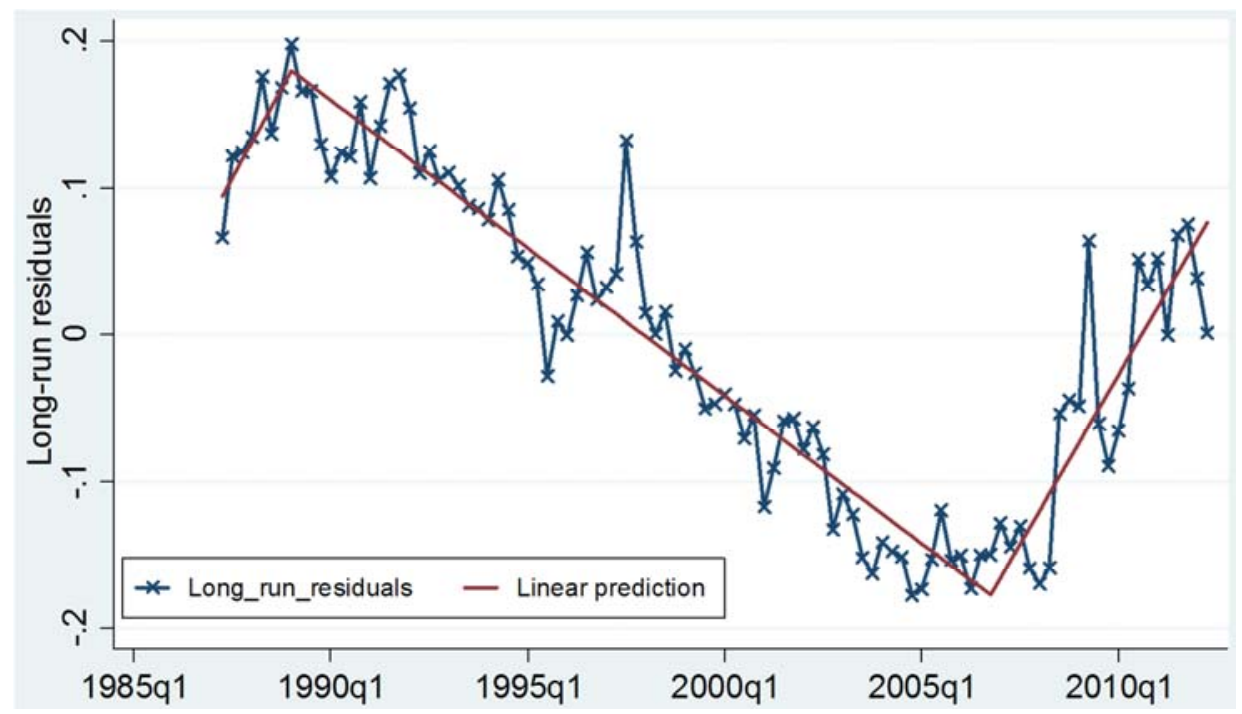

23. The estimation of the deterministic $f(T R E N D)$ terms proceeds in two steps. A first-stage equation excluding deterministic trends allows a test for the break-dates in the residuals of the long-term equation. In all countries in the sample, Quandt tests suggest that there is at least one structural break in the residuals of the long-run equation. Bai tests based on the residual sum of squares at all possible break-dates then allow the assessment of the exact break-date. ${ }^{6}$ The intercepts and slope parameters of the piece-wise deterministic trends are estimated simultaneously with the other parameters while typically imposing continuity at the break dates. In most countries, this procedure results in one or two structural breaks over the sample period so that long-run trends - which may reflect persistent changes in product quality or sluggish adjustment to changes in trade costs, e.g. in response to joining bilateral or multilateral trade agreements - have an average duration of around 7-10 years.

6. Following standard practice, the inner $70 \%$ of the sample are considered as possible break-dates, with the date minimising the residual sum of squares selected as the initial break-date. Additionally, the dates corresponding to the local minima of the residual sum of squares are selected if Bai tests suggest more than one break-date. In some cases, for instance if visual inspection of the residuals strongly suggests that the break in the long-term residuals appears to be at the beginning or the end of the sample rather than the inner $70 \%$, break-dates are selected manually. Given that the inner $70 \%$ of the sample generally does not fully encompass 2009, this is particularly important to allow for break-dates during the global trade collapse. Explicitly including 2009 for the statistical tests of structural breaks by considering the inner $80 \%$ of the sample does not affect break dates.

7. The maximum number of structural breaks per country is constrained to three. 
24. The inclusion of deterministic trends in the estimated equations improves in-sample fit, but requires careful out-of sample modelling. Simple pseudo out-of-sample forecasting exercises show that there is not a single modelling strategy with systematically superior forecasting performance across countries. In particular, pseudo out-of-sample forecasts covering the forecast period 2009Q1-2012Q4 were conducted assuming (i) the continuation of the most recent linear trend; (ii) a gradually flattening trend; ${ }^{8}$ and (iii) a flat trend. None of these modelling strategies appears to systematically minimise root mean squared forecasting error (RMSFE) across countries (Annex Tables A.14-A.17.). ${ }^{9}$ For the OECD Economics Department forecasting system, the gradually flattening trend is nonetheless chosen as the default option for all equations in all countries to avoid forecasts being unduly driven by immediate postcrisis developments.

25. The chosen modelling approach allows the re-estimation of the most recent deterministic trend at regular intervals, ensuring its consistency with recent trade developments. The main factor behind the deteriorating fit of the previous set of estimations was the assumption of gradually flattening out-of-sample trends that did not account for post-2002 trade developments. While the assumption of flattening trends is sensible when trade data are not available, i.e. for the forecasting period, it may be inconsistent with observed trade developments beyond the sample period underlying the estimations. Indeed, the estimations in this paper suggest that in many countries there were trend reversals beyond 2002, the last year of the sample period underlying the previous set of estimations (Annex Tables A.10-A.13). The re-estimation of the most recent deterministic trend assumes an unchanged intercept and unchanged coefficients of all other explanatory variables, basing the re-estimated slope coefficient on the residuals of the estimated long-term relation. In this way, large deviations from the previously estimated long-term relation are partly attributed to the re-estimated deterministic trend rather than triggering large adjustments to the long-run equilibrium in the early forecasting periods.

\section{Country groupings}

26. A key requirement for the coherence of trade forecasts based on the trade equations described above is that estimated parameters satisfy a number of theory-based priors on sign and statistical significance. For instance, export volumes are expected to increase in response to an increase in export market size. In some cases, due to small sample size or measurement error, estimated coefficients do not satisfy such theory-based priors. In these cases, grouped estimation instead of individual-country estimation increases sample size and thereby estimation efficiency. To avoid misrepresenting individual countries' trade dynamics, the validity of imposing common parameters within country groups needs to be tested formally.

27. The first step in constructing statistically valid country groups consists in heuristically classifying countries based on the degree of similarity in trade dynamics. In particular, cluster dissimilarity methods are applied to the parameters estimated from the individual-country regressions, which can be summarised in hierarchical tree diagrams (dendrograms). ${ }^{10}$ In the case of export volumes, for instance, the parameters

8. Each year the coefficient of the last in-sample deterministic trend is reduced by $1 / 2$.

9. To avoid a bias against the "flat trend" option due to structural breaks related to the trade collapse of 2009, the pseudo out-of-sample forecasting exercise was repeated for the forecast period 2004Q1-2007Q4. The results were similar to those reported for the period 2009Q1-2012Q4, with no modelling strategy systematically outperforming the others.

10. It should be noted that cluster dissimilarity methods are applied to vectors of coefficients from the individual-country regressions irrespective of statistical significance. It should also be noted that the cluster 
of China, Mexico, Indonesia, Greece and Poland appear to be relatively similar, with the cluster dissimilarity analysis suggesting two subgroups consisting of (i) China, Mexico and Indonesia, and (ii) Greece and Poland (Figure 2). Although there can at times be overlap between economic and statistical similarity, it should be noted that in this setup, country groupings reflect purely statistical criteria.

Figure 2. Preliminary country groupings (export volume equation)

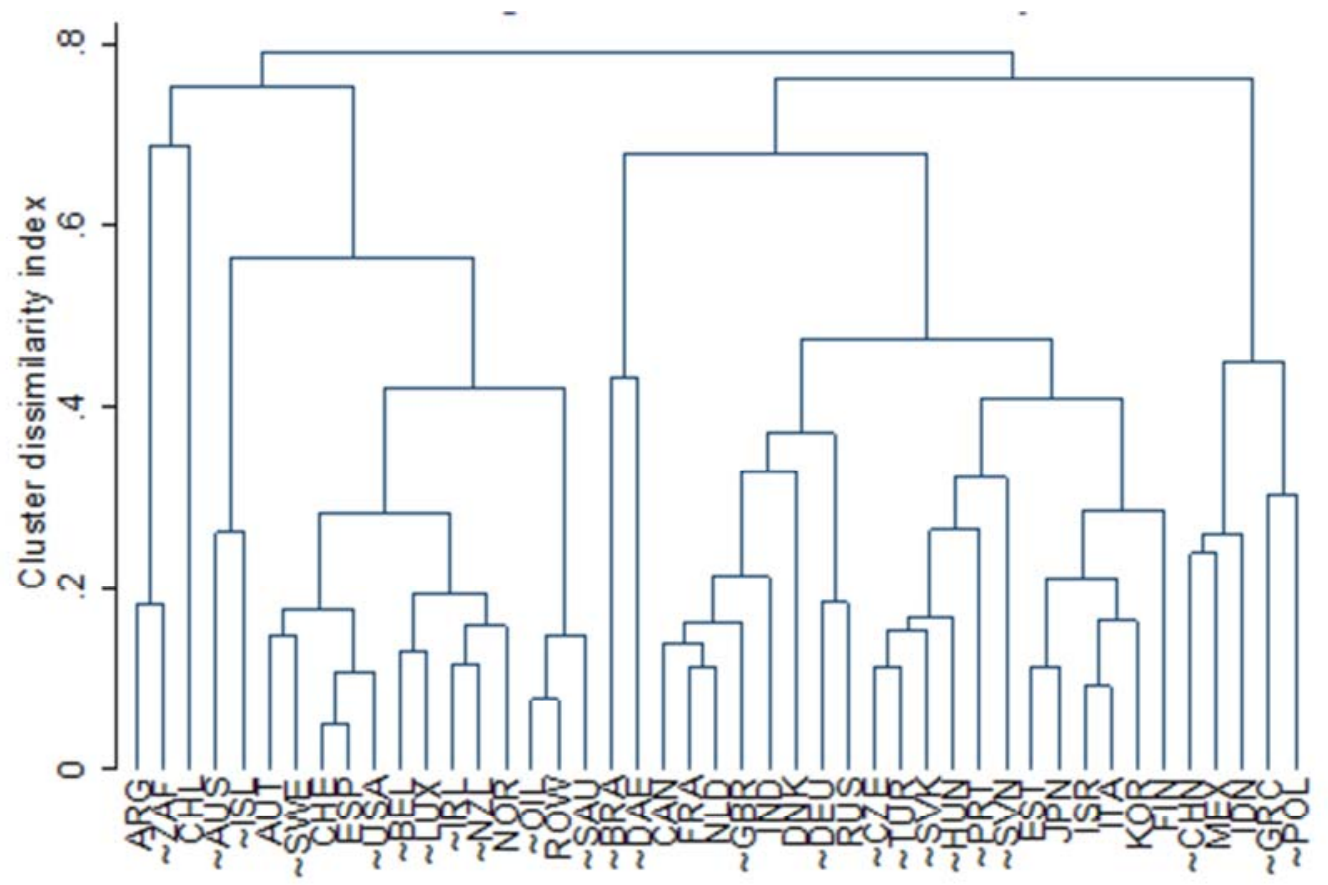

28. Based on this preliminary classification, countries failing to satisfy theory-based priors on sign and/or statistical significance (marked with a tilde in Figure 2) are grouped with statistically similar countries. The relevant equations are then re-estimated imposing common parameters for a subset of variables within groups. In the case of export volumes, for instance, Figure 2 suggests that the estimated parameters for Germany and the Russian Federation are similar, but that one or several of the coefficients in the equation for Germany is incorrectly signed and/or is not statistically significant. Indeed, the shortterm coefficient on the relative price of exports is positive and statistically not significant in the Germany equation (Table 1). Instead of maintaining the positive coefficient or setting it to zero for forecasting, it is chosen to impose a common coefficient on the relative price of exports. ${ }^{11}$

dissimilarity methods are applied only to the subset of parameters that are potentially constrained to be common within groups. For the export volume equation, for instance, these are: the parameter on the errorcorrection term; and the short- and long-run parameters on export prices relative to competitors.

11. In practice, the coefficients for Germany and Russia are estimated by pooled OLS, interacting all variables except the relative price of exports with country dummies. 
Table 1. Example of unconstrained and constrained estimation (export volume equation)

\begin{tabular}{|c|c|c|c|c|c|}
\hline & DEU & RUS & DEU & RUS \\
\hline & & unconstr. & unconstr. & constr. & constr. \\
\hline \multicolumn{2}{|c|}{ Dependent variable } & \multicolumn{4}{|c|}{$\Delta \ln X G S V$} \\
\hline \multirow[t]{4}{*}{ Long-run } & $\operatorname{InXMKT}_{-1}$ & 1 & 1 & 1 & 1 \\
\hline & & c & c & c & c \\
\hline & InRPXGS $_{-1}$ & $-0.18^{* *}$ & $-0.22^{\star \star *}$ & $-0.20^{\star \star \star}$ & $-0.22^{\star * *}$ \\
\hline & & $(0.07)$ & $(0.05)$ & $(0.08)$ & $(0.05)$ \\
\hline \multirow[t]{8}{*}{ Short-run } & $\Delta \mathrm{InXMKT}$ & $1.01^{* \star *}$ & $0.88^{* * *}$ & $0.99^{\star * *}$ & $0.83^{* * *}$ \\
\hline & & $(0.11)$ & $(0.26)$ & $(0.10)$ & $(0.25)$ \\
\hline & $\triangle \mathrm{InRPXGS}$ & 0.003 & $-0.10^{*}$ & $-0.08^{*}$ & $-0.08^{*}$ \\
\hline & & $(0.08)$ & $(0.06)$ & $(0.05)$ & $(0.05)$ \\
\hline & $\Delta \ln X G_{S V}-1$ & 0 & 0 & 0 & 0 \\
\hline & & C & c & $\mathrm{c}$ & $\mathrm{c}$ \\
\hline & ECM & $-0.61^{* * *}$ & $-0.65^{\star \star *}$ & $-0.59^{* * *}$ & $-0.65^{\star \star *}$ \\
\hline & & $(0.10)$ & $(0.13)$ & $(0.10)$ & $(0.14)$ \\
\hline \multicolumn{2}{|c|}{ F-test (p-value) } & & & 0.28 & 0.69 \\
\hline \multicolumn{2}{|l|}{$\mathrm{R}^{2}$} & 0.74 & 0.54 & 0.74 & 0.54 \\
\hline \multicolumn{2}{|c|}{ Observations } & 100 & 68 & 100 & 68 \\
\hline
\end{tabular}

Note: Robust standard errors in parentheses. ${ }^{*},{ }^{* *},{ }^{* \star *}$ denotes statistical significance at $10 \%, 5 \%, 1 \%$.

29. The validity of imposing cross-country constraints on the estimated parameters is tested by means of an F-test. If the null hypothesis of equality between the parameters from the individual-country estimations and the grouped estimation cannot be rejected, grouping based on the heuristic procedure described above is considered as valid. ${ }^{12}$ In case the null hypothesis is rejected, an iterative procedure tests other possible country groupings suggested by the cluster dissimilarity measure until statistically valid groups can be formed. In the above example of the Germany-Russia grouping suggested by the cluster dissimilarity method for the export volume equation, the F-tests do not reject statistical validity of the obtained country grouping at conventional levels of statistical significance. ${ }^{13}$

\subsection{Data}

30. Quarterly trade volumes and prices as well as domestic demand components are taken from the OECD Economic Outlook No. 92 database, with the trade aggregates described in Box 1 (export market size, relative export price and shadow price of imports) computed using a goods and services trade matrix

12. The F-test is based on the sum of squared residuals under constrained and non-constrained estimation. For each country member of the group, the following expression is calculated:

$$
F_{-} \text {estimated }=\frac{\operatorname{SSRC}-\operatorname{SSR} n c}{\operatorname{SSR} n c} \cdot \frac{n-k}{r} \sim F(r, n-k),
$$

Where SSRc is the sum of squared residuals under constrained (pooled) estimation, SSRnc is the sum of squared residuals under non-constrained (individual-country) estimation; $n$ is the number of observations; $k$ the number of explanatory variables plus the constant; and $r$ the number of constraints.

13. It should be noted that a small number of countries could not be assigned to country groupings in a statistically valid way. These countries were assigned to the statistically most similar grouping, imposing the grouping's coefficients to ensure the overall coherence of the estimations. 
for the year 2010. The estimations cover 41 countries, with the maximum sample length being 1987Q12012Q4. ${ }^{14}$

\section{Estimation results}

\subsection{Export volumes}

31. The estimation results for export volumes are reported in Annex Table A.2, with the implied cumulative response of export volumes to a $1 \%$ change in export market size or relative prices reported in Table A.6. A unit long-run elasticity is imposed for export market size so that in the long run export market performance is determined by relative prices and deterministic trends. The F-tests reported in Annex Table A.2 suggest that the cross-country constraints imposed by the 11 country groupings selected by the procedure described above are statistically valid.

32. The overall pattern of estimated long-run relative price elasticities is similar to that estimated in Pain et al. (2005). The highest long-run relative price elasticities are found for Mexico (-1.4) and Spain $(-1.3)$, which were among the most price sensitive countries in the previous set of estimations. High price elasticities may reflect the fact that these countries' export bundles include a comparatively high share of homogeneous products that are more exposed to international price competition than more differentiated products. Estimated long-run price elasticities are also relatively high (around -0.8) for Australia, Iceland, Italy, Israel, Japan and Korea. In most remaining countries long-run price elasticities are in the range of -0.5 to $-0.2 .{ }^{15}$ Among the $\mathrm{G} 7$ - consistent with the previous set of estimations - the lowest long-run price elasticity is found for Germany, which may reflect its highly differentiated export bundle and reputation for quality.

33. The statistical significance of deterministic trends suggests that long-run changes in export performance cannot be explained by relative export prices alone. In most countries deterministic trends are statistically significant over sub-periods or the entire sample period (Annex Table A.10). In the long term, countries appear to be gaining or losing market shares due to factors omitted from the estimated equations, such as quality changes in the bundle of exported goods or unobserved compositional changes.

34. In some emerging countries with high shares of commodity exports, the estimated deterministic trends contribute negatively to export performance toward the end of the sample period (Annex Table A.10). The largest negative contribution is estimated for South Africa and Chile, where deterministic trends imply declines in export growth of around $2 \frac{1}{2}-3 \%$ per year. Declining deterministic trends have reduced export growth by around $2 \%$ per year over the past decade in Brazil and by $1 \%$ per year in Argentina.

35. Export performance also appears to trend down in a number of higher-income OECD countries. This is the case for several G7 economies, such as Canada (-1\% per year), Japan (-0.9\%), Italy $(-0.7 \%)$ and the United Kingdom (-0.5\%), and smaller European economies, such as Finland (-1.3), Greece (-1.2), Austria (-0.7), Denmark (-0.7), Slovenia (-0.4) and to a lesser extent Belgium and Norway. In the United

14. See Annex Table A.1 for the precise list of covered countries. Due to missing data, sample size is significantly smaller for a number of BRIICS countries. For China, results for the trade price equations were unstable and are therefore not reported; disaggregated domestic demand components are not available so that the import equation for China was estimated using total domestic demand.

15. A notable exception is Brazil, which has the lowest estimated long-run price elasticity in the sample (around -0.1). 
States, the contribution of the deterministic trend to export performance is broadly neutral toward the end of the sample.

36. Large positive contributions of deterministic trends to export performance are found for India (around 3\% per year), China (around 2\% per year), as well a number of Central and Eastern European economies and Germany (ranging from around $1 / 2$ per cent to $1 \%$ per year). Positive trend contributions have been sustained over the past 10-15 years, with most of these countries gaining substantial shares in world markets over this period. The contribution of deterministic trends to export market performance has recently shifted from negative to positive in Indonesia (3\% per year at the end of the sample period).

37. In the short term, some countries gain market shares at the expense of others in response to a shock in export market size. The dynamic response of export volumes to changes in export market size and relative prices is determined by the error correction terms together with the short-run parameters for export market growth, real exchange rate changes and lagged export volume growth (Annex Table A.6). ${ }^{16}$ In a number of countries (Brazil, Czech Republic, Estonia, Finland, Hungary, Japan, Korea, Portugal, Slovakia, Slovenia and Turkey), there is significant overshooting in response to a foreign demand shock in the sense that export volumes increase by more than export market size in the short term, while adjustment is more gradual in the remaining countries. In all countries except Iceland, Ireland and New Zealand, adjustment to foreign demand shocks is relatively quick, with most of the adjustment taking place over the first year. ${ }^{17}$

\subsection{Import volumes}

38. The results for import volumes are reported in Annex Table A.3, with the implied cumulative response functions to a $1 \%$ change in disaggregate expenditure components and to a $1 \%$ change in relative import prices reported in Annex Table A.7. No constraint on the sum of disaggregate expenditure elasticities is imposed so that in the long term import penetration may vary in response to an aggregate expenditure shock, even in the absence of deterministic time trends. This reflects the statistical rejection of such constraints in most countries and is consistent with prima facie evidence that import penetration appears to respond more than one-to-one to expenditure fluctuations. For some countries, F-tests reported in Table A.3 suggest that the cross-country constraints imposed by the grouping procedure described above results in significantly different coefficients than the individual-country estimations. In these cases, no alternative cross-country constraints could be found that satisfied theoretical priors on the positive sign of the domestic demand variables and the negative sign of the relative price variable.

39. Reflecting the high share of private consumption in total expenditure in most countries, imports generally respond more strongly to a $1 \%$ increase in private consumption than to a $1 \%$ increase in investment or public consumption. The higher import content of investment imposed in the estimations is more than offset by the larger share of private consumption in most countries. The low elasticity of imports

16. It should be noted that the error-correction terms are precisely estimated and correctly signed for all countries in the sample, suggesting that the variables included in the long-term relation are indeed cointegrated (Annex Table A.3). Banerjee et al. (1998) provide critical values for error correction mechanism-based tests of co-integration.

17. It should be noted that at the global level a $1 \%$ increase in each country's export market needs to be matched by a $1 \%$ increase in global exports, implying that overshooting of exports in response to a foreign demand shock needs to be offset by sluggish adjustment in others. While approximately satisfied by the impulse responses reported in Annex Table A.6, no such global adding-up constraint was formally imposed. The reason is that export market size is calculated using all trading partners, while export equations are only estimated for a subset of countries so that the global adding-up constraint would likely be violated. 
with respect to public consumption reflects both its low share in total expenditure and its low import content imposed in the estimations. The marginal import propensities implied by the constraints are close to those commonly reported in cross-country analyses of input-output tables (Bussière et al., 2011; Claus and $\mathrm{Li}, 2003$ ), with the implied median import propensities across countries: 0.4 for investment, 0.3 for private consumption, 0.1 for government consumption and 0.5 for exports.

40. The pattern of import propensities implied by the estimated long-run elasticities of imports to exports is consistent with patterns of trade in value added. High implied import propensities of exports are obtained in a number of small open economies, such as the Benelux countries, several Central and Eastern European countries, Ireland or Korea. At the same time, trade in value added data constructed in OECDWTO (2013) suggest that these countries are characterised by relatively low shares of value added in gross exports, which reflects these countries' high degree of integration with global production chains More generally, it appears that the import propensities of exports implied by the estimated long-run elasticities are closely correlated with the pattern of trade in value added (Figure 3).

Figure 3. Trade in value added and implied import propensity of exports (2009)

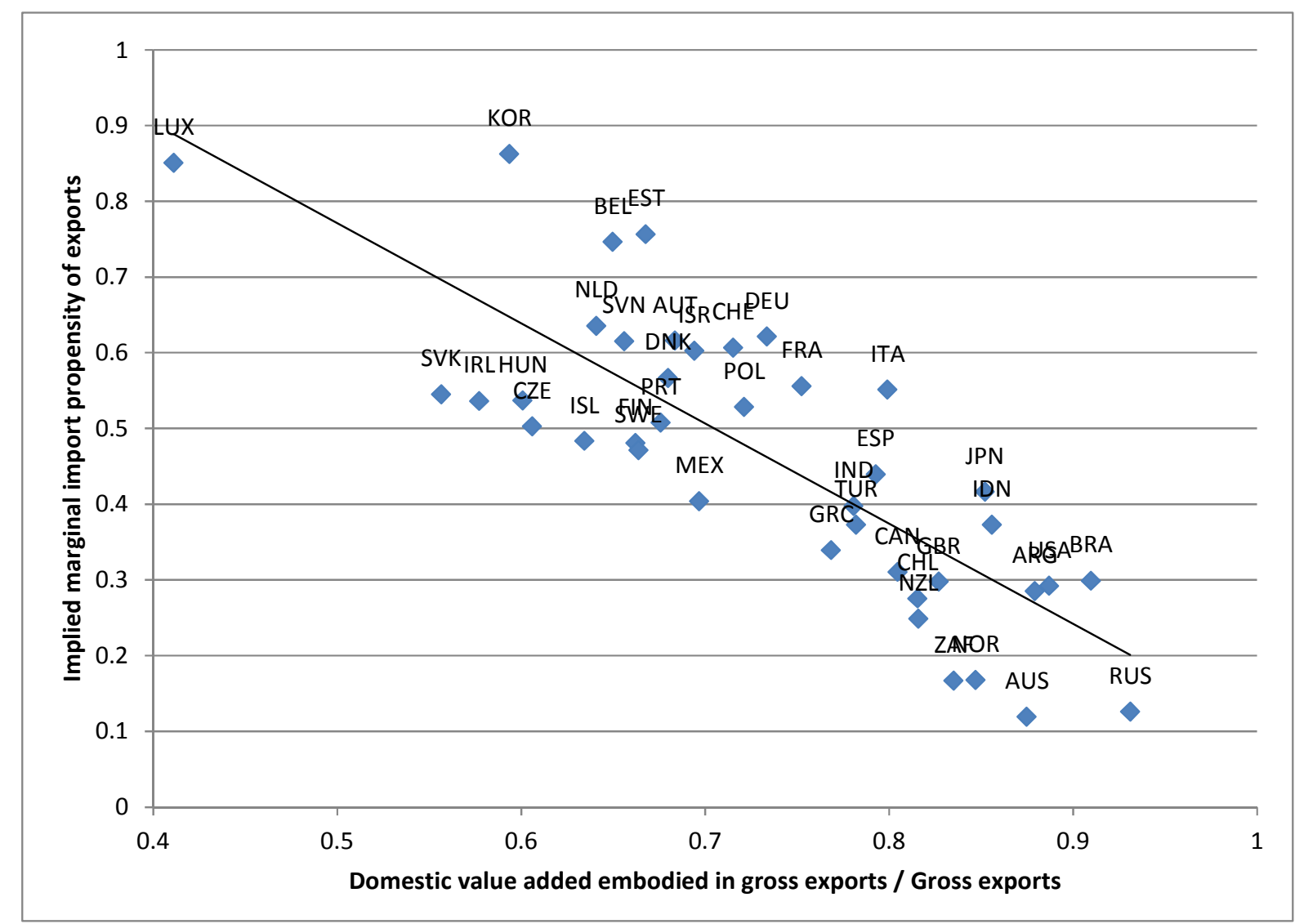

Note: The implied marginal import propensity of exports is computed as the estimated elasticity of imports to exports multiplied by the pre-crisis average of the ratio of exports to imports.

Source: OECD ADB and OECD-WTO Trade in Value Added (TiVA) databases. 
41. For most countries the long-run elasticity of imports to total expenditure is well above 1, reflecting rapid increases in import penetration over the sample period. ${ }^{18}$ The long-run elasticity is particularly large for a number of emerging countries, such as Brazil, Chile, Indonesia or Mexico, which experienced large increases in import penetration over the sample period. The long-run elasticity is typically lower in higher-income countries with already high values of import penetration at the beginning of the sample period. The dynamic adjustment to expenditure shocks is fairly quick, with more than $80 \%$ of the adjustment taking place within the first year in most countries.

42. The contribution of deterministic trends to import volume growth is significant in a number of countries (Annex Table A.11). In the present estimation setup, the long-run elasticity of imports to total expenditure is not constrained to 1, implying that the trend increase in import penetration observed in most countries may be picked up by total expenditure elasticities larger than one. Deterministic trends in this setup adjust only long-run import penetration trends implied by total expenditure and relative import price developments up or down. Countries with negative contributions of deterministic trends to import growth at the end of the sample include: Argentina, China, Indonesia, Israel and Turkey. By contrast, deterministic trends raise import penetration at the end of the sample beyond what is implied by total expenditure and relative import price developments in the Czech Republic, Estonia, Hungary, India, the Netherlands, Russia and the Slovak Republic.

43. The long-term relative price elasticities of imports are typically in a similar range as the elasticities of exports, in most countries between -0.15 and -0.4 . In a number of small open economies, including the Czech Republic, Denmark, Luxembourg and the Netherlands, the long-term relative price elasticity of imports is particularly high. As in the previous set of estimations, a notable feature of the import and export volume equations is that in some countries and under certain conditions a nominal exchange rate depreciation could lead to a decline in the trade balance. This could be the case when the sum of absolute relative price elasticities in the import and export equations is smaller than $1 .{ }^{19}$

\subsection{Export prices}

44. The results for export prices are reported in Table A.4., with the implied cumulative response functions to $1 \%$ changes in competitors' prices or domestic prices reported in Annex Table A.8. The sum of the long-run coefficients on competitors' prices and domestic prices is constrained to 1 . The F-tests reported in Annex Table A.4 suggest that the six country groupings selected by the grouping procedure described above are statistically valid.

45. The estimations suggest a significant degree of long-run pricing-to-market behaviour by exporters in most countries, with the estimated elasticity of export prices to competitors' prices typically

18. Import penetration is here defined as the ratio of import volumes to the sum of real total domestic demand and export volumes.

19. The basic Marshall-Lerner condition states that an exchange rate depreciation raises the trade balance if the sum of the absolute values of relative price elasticities in the import and export volume equations exceeds 1. However, the Marshall-Lerner condition is derived under the assumption that exchange rate changes are fully passed through to import prices (i.e. import prices in foreign currency remain constant, suggesting foreign exporters do not price to market) while there is no pass-through from exchange rate changes to export prices (i.e. export prices in domestic currency remain constant, suggesting domestic exporter do not price to market). However, in imperfectly competitive markets exporters absorb nominal exchange rate changes partly in their profit margins, thereby invalidating the assumptions underlying the derivation of the Marshall-Lerner condition. Indeed, the estimated export equations reported below suggest that there is some degree of pricing to market in most countries. 
ranging between 0.3 and 0.6. Estimated elasticities are larger for a number of emerging countries with large shares of commodities in their export baskets, including Argentina, Brazil and Indonesia, suggesting that these countries are price takers on world markets. By contrast, a number of higher-income OECD countries that produce more differentiated products, including Germany, Japan and the United States, set export prices according to domestic costs, suggesting monopoly power on world markets. High estimated elasticities of domestic prices for India and Luxembourg may reflect high shares of services in export baskets.

46. For most countries, deterministic trends contribute negatively to export price growth over the period 1995-2012 (Annex Table A.12). This may reflect the composition of exports, which include predominantly manufactured goods, relative to the composition of domestic demand, which includes predominantly services. As in the long run export price growth is a weighted sum of increases in domestic prices and competitors' prices, lower manufacturing price growth relative to services would be picked up only incompletely by declining competitors' prices. ${ }^{20}$ Declining deterministic trends in the export equation may also reflect increased competition on world markets, which may have forced exporters to increasingly price to market and reduce their profit margins.

47. For more than half of the studied countries, a statistically significant coefficient is estimated for the nominal exchange rate variable, suggesting a different initial response to nominal exchange rate changes than to competitors' prices in US dollar terms (Annex Table A.4). In a number of European countries (Austria, Belgium, the Czech Republic, Germany, Denmark, Estonia, France, Italy, the Netherlands, Norway, Portugal, the Slovak Republic and Slovenia), the coefficient on the nominal exchange rate term is positive, implying that the initial export price response to a nominal exchange rate change is smaller than to a change in foreign prices in US dollar terms. By contrast, in Brazil, Canada, Japan, Israel, Korea, Mexico, South Africa and Turkey the initial response to exchange rate changes is estimated to be stronger than to changes in foreign prices in US dollar terms.

48. The estimated coefficient on the error correction term is statistically significant in all countries and in the range -0.2 and -0.5 for most. Adjustment to the long-term equilibrium is particularly quick for Greece, India, Mexico and Poland, for which the estimated coefficients are around -0.9 , whereas it is particularly slow for Japan (-0.05).

\subsection{Import prices}

49. The results for import prices are reported in Annex Table A.5, with the implied cumulative response functions to $1 \%$ changes in competitors' prices or domestic prices reported in Annex Tables A.9. The sum of the long-run coefficients on competitors' prices and domestic prices is constrained to 1 . The Ftests reported in Annex Table A.5 suggest that the seven country groupings selected by the grouping procedure described above are statistically valid.

50. In most countries, there is clear evidence for pricing to market as reflected by estimated coefficients on domestic prices that are statistically different from 0 . The only exceptions are a number of emerging countries, such as Indonesia, India and Mexico, where import prices are independent of domestic price developments, so that changes in shadow prices - including those driven by nominal exchange rate

20. Note that among the few countries with trend increases in export prices toward the end of the sample are countries with high shares of commodity exports, such as Argentina, Australia, Brazil and South Africa, despite export prices in principle being corrected for commodity price effects. This suggests that the commodity price correction may be imperfect or that there is considerable spillover from commodity prices to other export prices, including through the exchange rate. 
changes - are fully passed through to import prices. The statistically significant but low estimated elasticity of domestic prices in Argentina suggests nearly complete pass-through. While in most other countries the estimated elasticity on domestic prices is in the range 0.2 to 0.6 , estimated elasticities are around 0.8 in Japan and the United States, suggesting high degrees of pricing to market in these countries.

51. As in the export price equations, in most countries deterministic trends have typically contributed negatively to import price growth over the sample period (Annex Table A.13). This may reflect similar shifts in pricing-to-market behaviour or compositional effects as for export prices.

52. For around $60 \%$ of the countries in the sample, a statistically significant coefficient is estimated for the nominal exchange rate variable, suggesting a different initial response to nominal exchange rate changes than to competitors' prices in US dollar terms (Annex Table A.5). In most of these countries the coefficient on the nominal exchange rate term is positive, implying that the initial export price response to a nominal exchange rate change is smaller than to a change in foreign prices in US dollar terms. However, in Argentina, Brazil, Canada, Israel, Korea, New Zealand, Russia and South Africa, the initial response of import prices to exchange rate changes is estimated to be larger than to changes in foreign prices in US dollar terms.

53. Adjustment to the long-run equilibrium is estimated to be relatively quick, with the estimated coefficients on the error adjustment terms statistically significant and typically in the range -0.2 to -0.5 . Adjustment is estimated to be particularly quick in Brazil, Chile, the Czech Republic and Hungary, while it is estimated to be particularly slow in Canada, Indonesia and South Africa. 


\section{REFERENCES}

Banerjee, A., J. Dolado and R. Mestre (1996), "Error-correction tests for cointegration in a single-equation framework", Journal of Time Series Analysis 19(3):267-283.

Brézillon, J., S. Guichard and D. Turner (2010), "Trade linkages in the OECD trade system”, OECD Economics Department Working Paper No. 811, OECD Publishing.

Bussière, M., G. Callegari, F. Ghironi, G. Sestieri and M. Yamano (2013), "Estimating trade elasticities: Demand elasticities and the trade collapse of 2008-09", American Economic Journal: Macroeconomics 5(3):118-151

Cheung, C. and S. Guichard (2009), "Understanding the world trade collapse", OECD Economics Working Paper No. 729, OECD Publishing.

Guichard, S. and E. Rusticelli (2011), “A Dynamic Factor Model for world trade growth”, OECD Economics Working Paper No. 874, OECD Publishing.

OECD-WTO (2013), Trade in Value Added (TiVA) database.

Pain, N., A. Mourougane, F. Sédillot and L. Le Fouler (2005), "The new OECD international trade model”, OECD Economics Department Working Paper No. 440, OECD Publishing. 


\section{ANNEX 1 - FIGURES}

Figure A.1. Share of world exports in 2000 and 2010
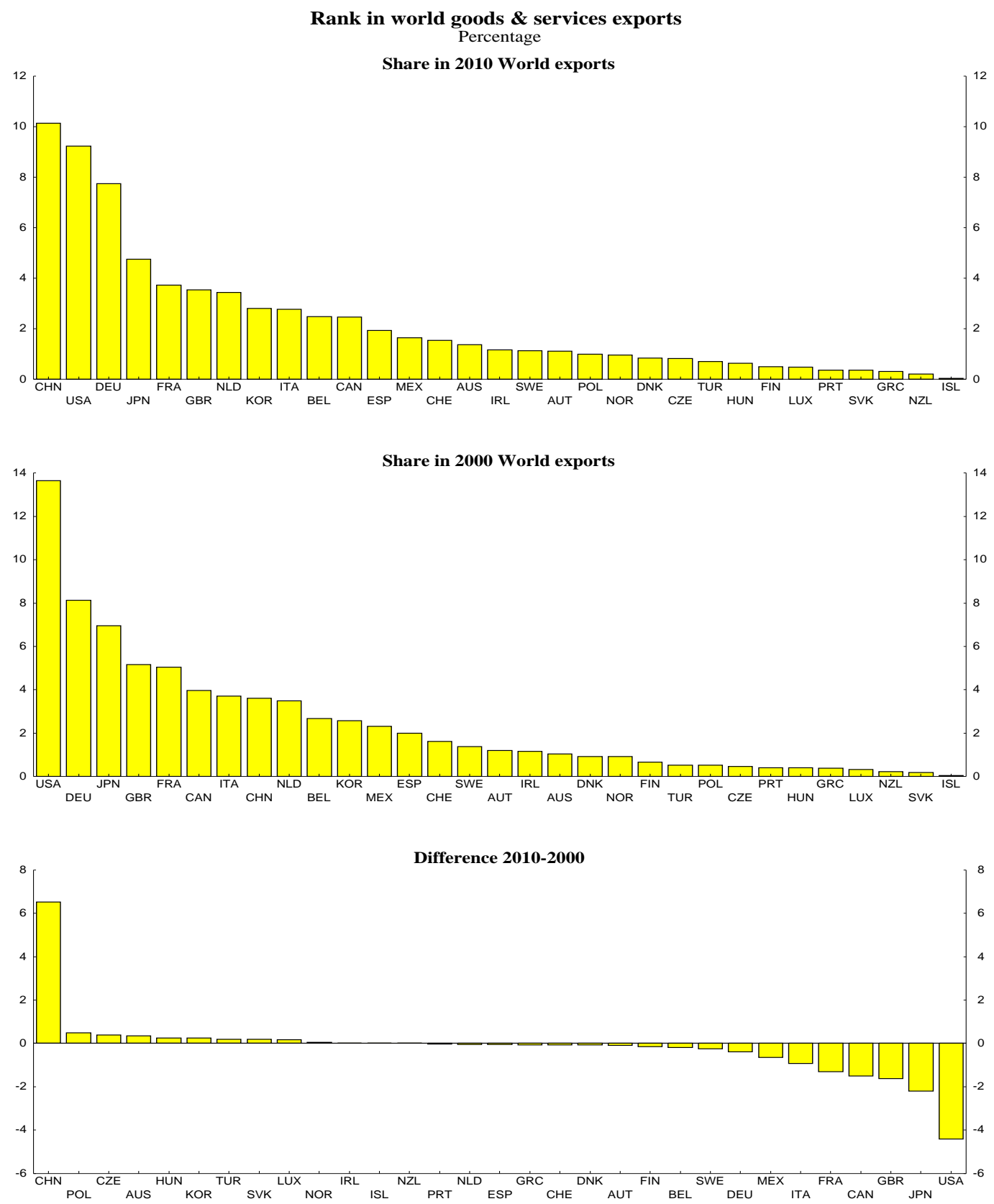

Note: Based on harmonised trade matrices described in Brézillon et al. (2010). Brazil, India, Indonesia, Russia and Indonesia were not included as individual countries in the trade matrix for 2000 so that for these countries the comparison over time is not feasible. 
Figure A.2. Share of world imports in 2000 and 2010
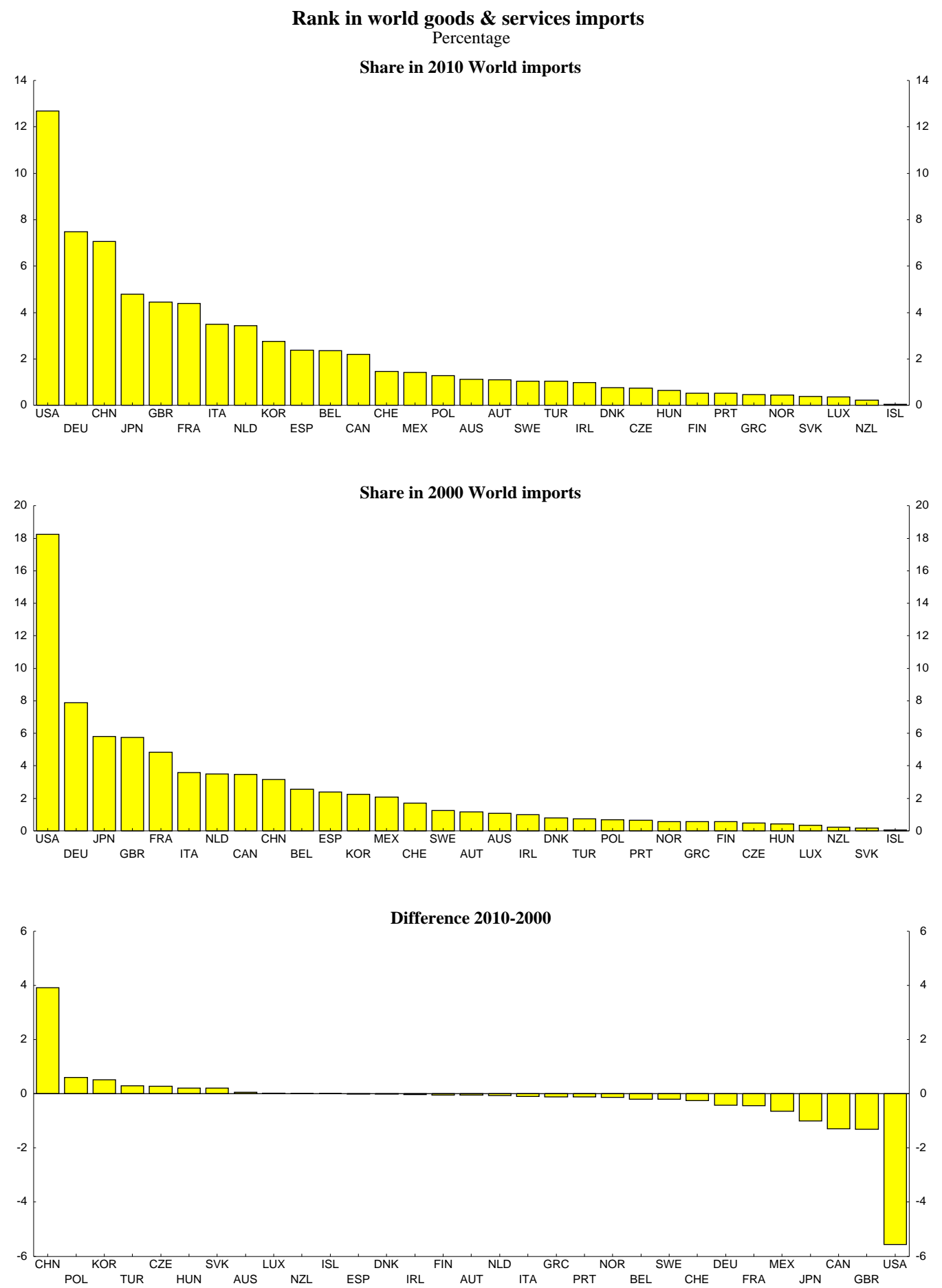

Note: Based on harmonised trade matrices described in Brézillon et al. (2010). Brazil, India, Indonesia, Russia and Indonesia were not included as individual countries in the trade matrix for 2000 so that for these countries the comparison over time is not feasible. 
Figure A.3. Shares of world exports and imports in 2000 and 2010 by major trading regions

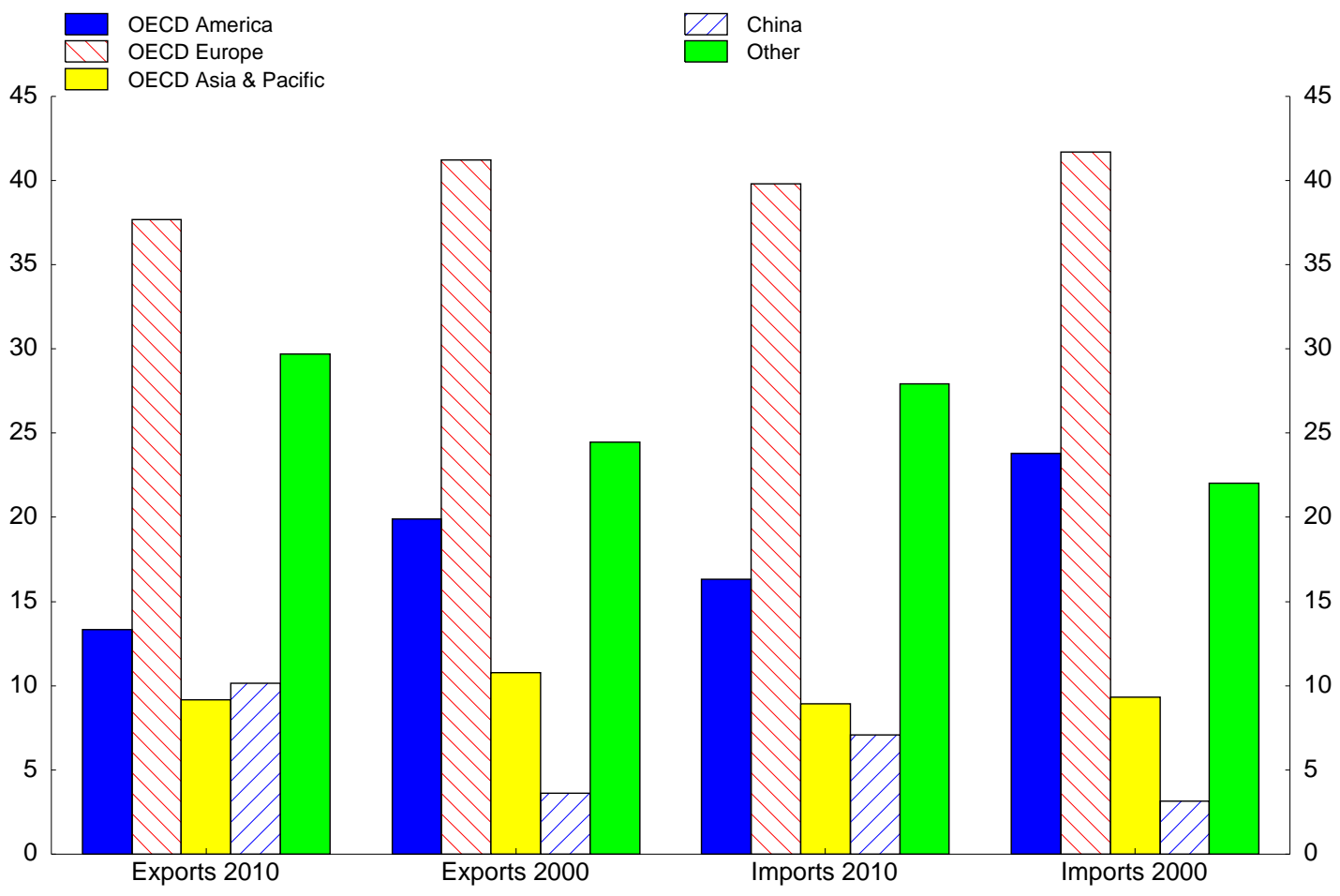

Difference 2010-2000

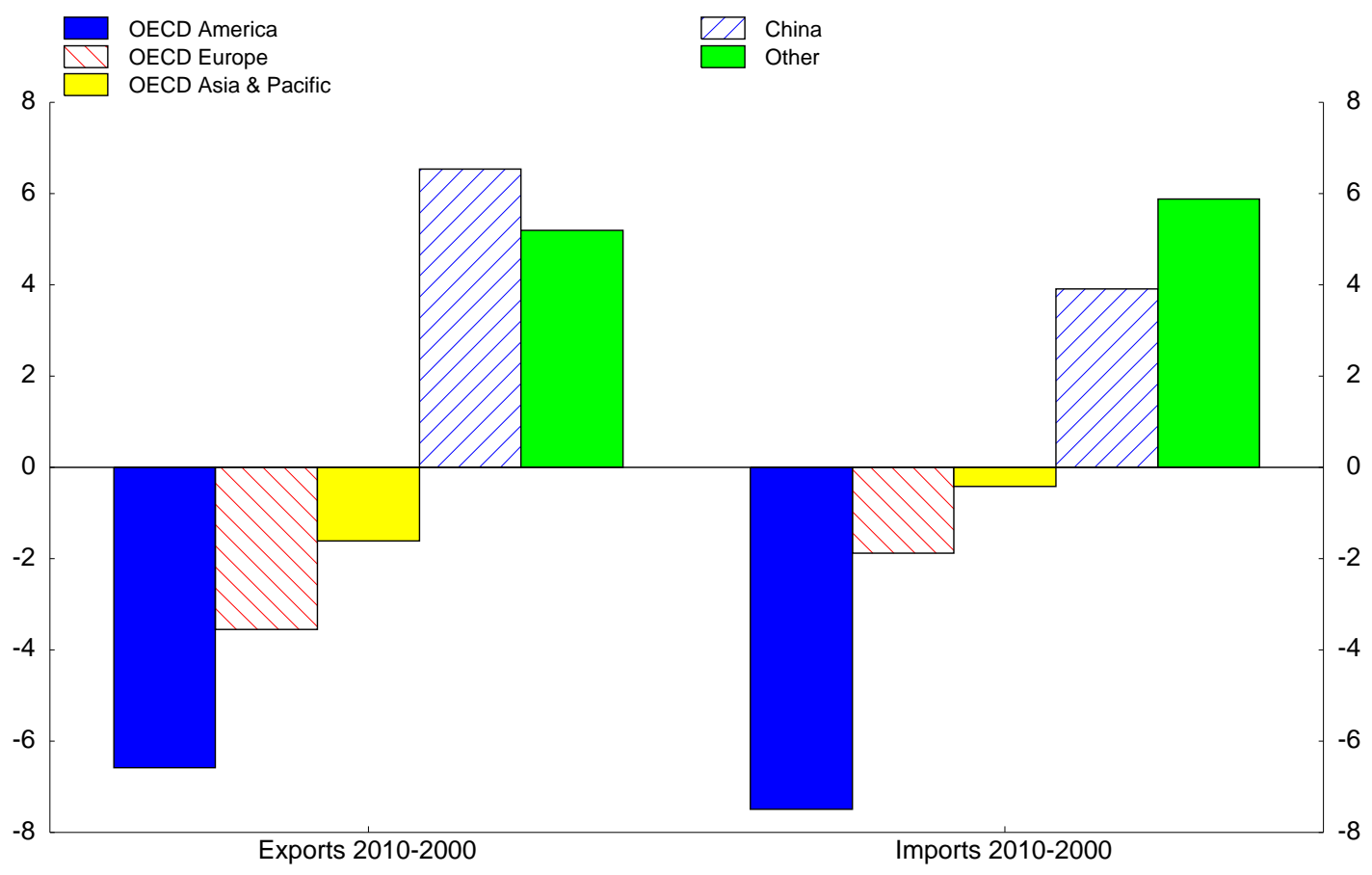


Figure A.4. Export market growth based on 2000 versus 2010 trade matrix
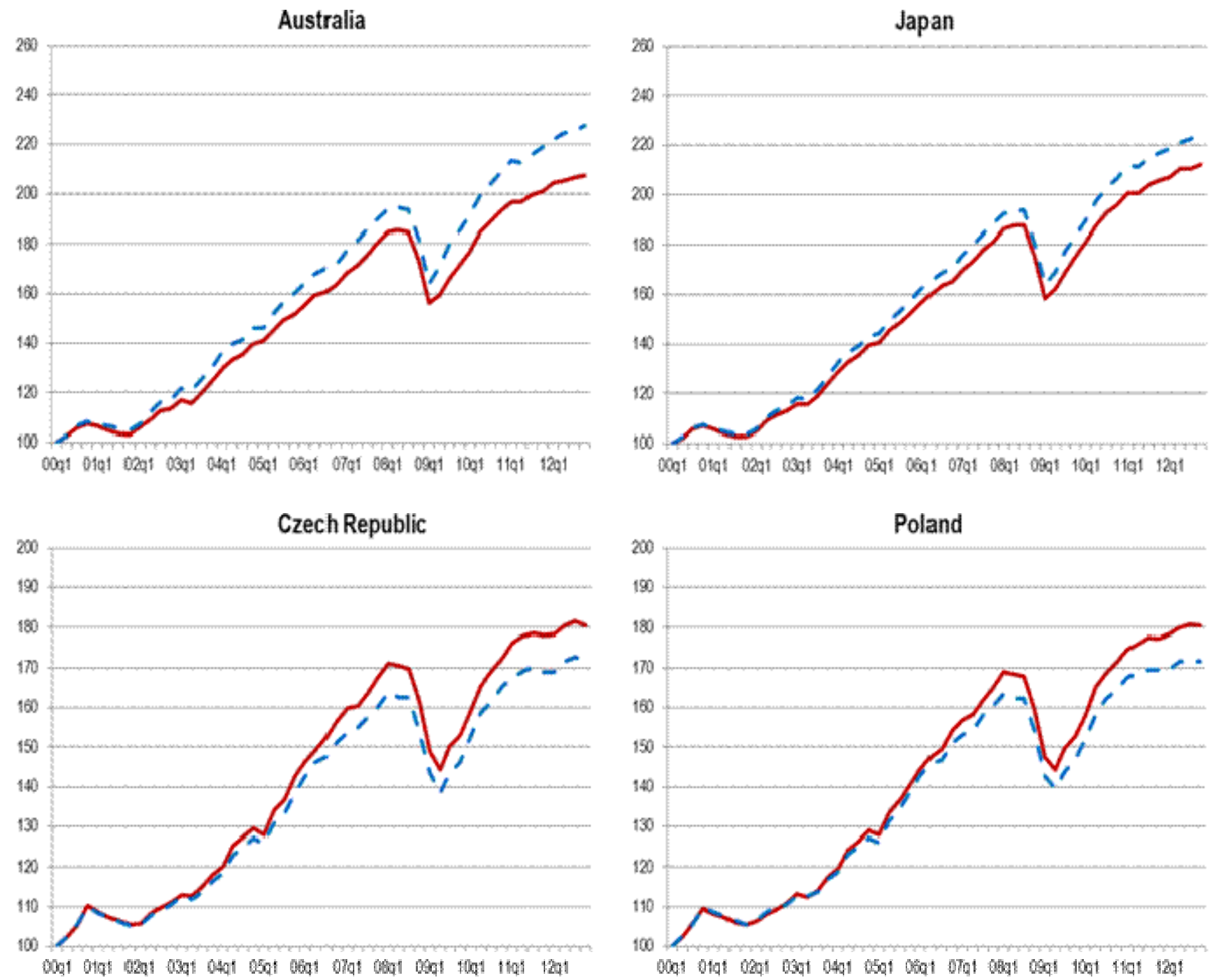

USA
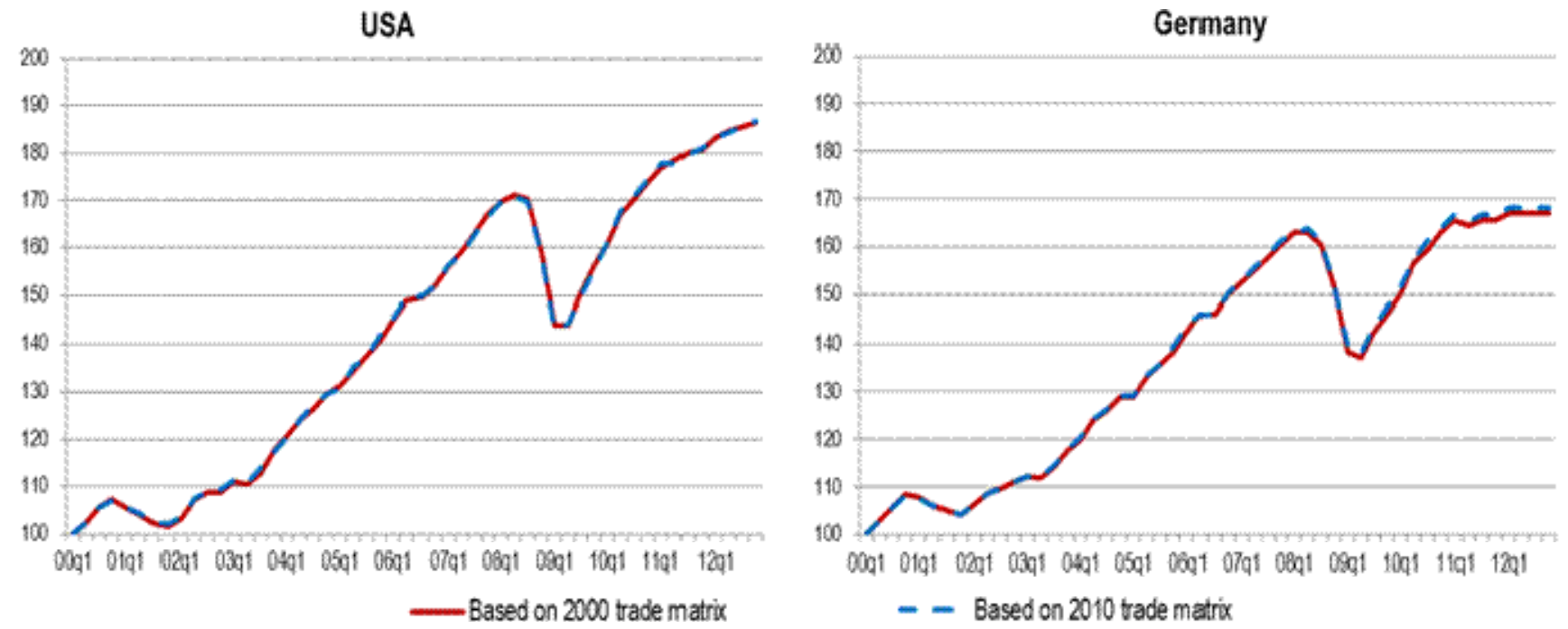
ANNEX 2 - TABLES

Table A.1. List of covered countries and country abbreviations

\begin{tabular}{|c|c|}
\hline Country & Abbreviation \\
\hline Argentina & ARG \\
\hline Australia & AUS \\
\hline Austria & AUT \\
\hline Belgium & BEL \\
\hline Brazil & BRA \\
\hline Canada & CAN \\
\hline Switzerland & $\mathrm{CHE}$ \\
\hline Chile & $\mathrm{CHL}$ \\
\hline China & $\mathrm{CHN}$ \\
\hline Czech Republic & CZE \\
\hline Germany & DEU \\
\hline Denmark & DNK \\
\hline Spain & ESP \\
\hline Estonia & EST \\
\hline Finland & FIN \\
\hline France & FRA \\
\hline United Kingdom & GBR \\
\hline Greece & GRC \\
\hline Hungary & HUN \\
\hline Indonesia & IDN \\
\hline India & IND \\
\hline Ireland & $\mathrm{IRL}$ \\
\hline Iceland & ISL \\
\hline Israel & ISR \\
\hline Italy & ITA \\
\hline Japan & JPN \\
\hline Korea & KOR \\
\hline Luxembourg & LUX \\
\hline Mexico & MEX \\
\hline Netherlands & NLD \\
\hline Norway & NOR \\
\hline New Zealand & NZL \\
\hline Poland & POL \\
\hline Portugal & PRT \\
\hline Russian Federation & RUS \\
\hline Slovak Republic & SVK \\
\hline Slovenia & SVN \\
\hline Sweden & SWE \\
\hline Turkey & TUR \\
\hline United States & USA \\
\hline South Africa & ZAF \\
\hline
\end{tabular}


Table A.2. Estimated export volume equations

\begin{tabular}{|c|c|c|c|c|c|c|c|c|c|c|}
\hline & ARG & AUS & AUT & BEL & BRA & CAN & CHE & $\mathrm{CHL}$ & CHN & CZE \\
\hline Groups & G1 & G1 & G3 & G6 & G8 & & G5 & & G10 & G7 \\
\hline \multirow[t]{2}{*}{ Sample } & $1993 q 3$ & $1987 q 3$ & $1987 q 3$ & $1987 q 3$ & $1996 q 3$ & 1987q3 & $1987 q 3$ & $1995 q 3$ & $1987 q 3$ & $1991 q 3$ \\
\hline & $2012 q 2$ & $2012 q 2$ & $2012 q 2$ & $2012 q 2$ & $2012 q 2$ & $2012 q 2$ & $2012 q 2$ & $2012 q 2$ & $2012 q 2$ & $2012 q 2$ \\
\hline \multicolumn{11}{|l|}{ LONG RUN } \\
\hline \multirow[t]{2}{*}{$\ln X M K T_{-1}$} & 1 & 1 & 1 & 1 & 1 & 1 & 1 & 1 & 1 & 1 \\
\hline & C & C & C & C & C & C & C & c & $\mathrm{C}$ & C \\
\hline \multirow[t]{2}{*}{$\operatorname{InRPXGS}_{-1}$} & $-0.201^{* * *}$ & $-0.830^{* * *}$ & $-0.340^{* * *}$ & $-0.439 * * *$ & $-0.0809^{* * *}$ & $-0.623^{* * *}$ & $-0.639^{* * *}$ & $-0.165^{\star \star \star}$ & $-0.445^{\star *}$ & $-0.352^{* *}$ \\
\hline & $(0.060)$ & $(0.058)$ & $(0.095)$ & $(0.132)$ & $(0.022)$ & $(0.126)$ & $(0.210)$ & $(0.062)$ & $(0.189)$ & $(0.161)$ \\
\hline \multicolumn{11}{|l|}{ SHORT RUN } \\
\hline \multirow[t]{2}{*}{$\Delta \operatorname{lnXMKT}$} & $0.750 * * *$ & 0.750 & $0.664^{* * *}$ & $0.448^{* * *}$ & $1.279^{* * *}$ & $0.840^{* * *}$ & $0.778 * * *$ & $0.332^{*}$ & $0.946^{* * *}$ & $1.109^{* * *}$ \\
\hline & $(0.129)$ & C & $(0.068)$ & $(0.058)$ & $(0.066)$ & $(0.088)$ & $(0.061)$ & $(0.183)$ & $(0.092)$ & $(0.084)$ \\
\hline \multirow[t]{2}{*}{$\triangle \operatorname{InRPXGS}$} & $-0.432^{* * *}$ & $-0.232^{* * *}$ & $-0.0798^{* *}$ & $-0.114^{* * *}$ & $-0.145^{\star *}$ & $-0.167^{*}$ & $-0.137^{* * *}$ & $0.194^{* *}$ & $-0.889^{* * *}$ & -0.139 ** \\
\hline & $(0.092)$ & $(0.086)$ & $(0.035)$ & $(0.034)$ & $(0.068)$ & $(0.088)$ & $(0.041)$ & $(0.085)$ & $(0.053)$ & $(0.057)$ \\
\hline \multirow[t]{2}{*}{$\Delta \ln X G_{S V}$} & 0 & 0 & $0.303^{* * *}$ & $0.218^{\star * *}$ & 0 & 0 & 0 & 0 & 0 & 0 \\
\hline & $\mathrm{C}$ & $\mathrm{C}$ & $(0.067)$ & $(0.080)$ & c & C & C & c & c & c \\
\hline \multirow[t]{2}{*}{ ECM } & $-0.756^{* * *}$ & $-0.360^{* * *}$ & $-0.217^{* * *}$ & $-0.126^{* * *}$ & $-0.947^{* * *}$ & $-0.366^{* * *}$ & $-0.112^{* * *}$ & $-0.806^{* * *}$ & $-0.202^{* * *}$ & $-0.215^{\star * *}$ \\
\hline & $(0.074)$ & $(0.059)$ & $(0.044)$ & $(0.024)$ & $(0.136)$ & $(0.077)$ & $(0.031)$ & $(0.105)$ & $(0.032)$ & $(0.032)$ \\
\hline$\overline{R^{2}}$ & 0.546 & 0.554 & 0.694 & 0.779 & 0.795 & 0.597 & 0.587 & 0.613 & 0.691 & 0.604 \\
\hline F-test (p-value) & 0.61 & 0.00 & 0.68 & 0.42 & 0.66 & - & 0.97 & - & 0.44 & 0.91 \\
\hline \multirow[t]{2}{*}{ Observations } & 76 & 100 & 100 & 100 & 64 & 100 & 100 & 68 & 100 & 84 \\
\hline & DEU & DNK & ESP & EST & FN & FRA & GBR & GRC & HUN & IDN \\
\hline Groups & G2 & & & G7 & & & G4 & G10 & G7 & G10 \\
\hline \multirow[t]{2}{*}{ Sample } & $1987 q 3$ & $1987 q 3$ & $1987 q 3$ & $1995 q 3$ & $1987 q 3$ & $1987 q 3$ & $1987 q 3$ & $1992 q 3$ & $1995 q 3$ & $1990 q 3$ \\
\hline & $2012 q 2$ & $2012 q 2$ & $2012 q 2$ & $2012 q 2$ & $2012 q 2$ & $2012 q 2$ & $2012 q 2$ & $2012 q 2$ & $2012 q 2$ & $2012 q 2$ \\
\hline \multicolumn{11}{|l|}{ LONG RUN } \\
\hline \multirow[t]{2}{*}{$\ln X \mathrm{MKT}_{-1}$} & 1 & 1 & 1 & 1 & 1 & 1 & 1 & 1 & 1 & 1 \\
\hline & c & C & C & $\mathrm{C}$ & C & c & C & C & C & C \\
\hline \multirow[t]{2}{*}{ InRPXGS -1} & $-0.203^{\star * *}$ & $-0.518^{* * *}$ & $-1.288^{* * *}$ & $-0.352^{* *}$ & $-0.539^{* * *}$ & $-0.292^{\star * *}$ & $-0.420^{* * *}$ & $-0.445^{\star *}$ & $-0.352^{* *}$ & $-0.445^{* *}$ \\
\hline & $(0.0760)$ & $(0.146)$ & $(0.439)$ & $(0.161)$ & $(0.178)$ & $(0.084)$ & $(0.095)$ & $(0.189)$ & $(0.161)$ & $(0.189)$ \\
\hline \multicolumn{11}{|l|}{ SHORTRUN } \\
\hline \multirow[t]{2}{*}{$\Delta \ln X \mathrm{MKT}$} & $0.986^{* * *}$ & $0.614^{* * *}$ & $0.745^{* * *}$ & $1.109^{* * *}$ & $1.478^{* * *}$ & $0.890^{* * *}$ & $0.888^{* * *}$ & $0.946^{\star * *}$ & $1.109^{\star * \star}$ & $0.946^{* * *}$ \\
\hline & $(0.101)$ & $(0.091)$ & $(0.139)$ & $(0.084)$ & $(0.163)$ & $(0.076)$ & $(0.043)$ & $(0.092)$ & $(0.084)$ & $(0.092)$ \\
\hline \multirow[t]{2}{*}{$\Delta \operatorname{InRPXGS}$} & $-0.0832^{*}$ & $-0.317^{* * *}$ & $-0.133^{* *}$ & $-0.139 * *$ & $-0.408^{* * *}$ & $-0.0999^{*}$ & $-0.140^{* * *}$ & $-0.889^{* * *}$ & $-0.139 * *$ & $-0.889 * * *$ \\
\hline & $(0.0496)$ & $(0.103)$ & $(0.067)$ & $(0.057)$ & $(0.144)$ & $(0.051)$ & $(0.042)$ & $(0.053)$ & $(0.057)$ & $(0.053)$ \\
\hline \multirow[t]{2}{*}{$\Delta \ln X G_{S V}$} & 0 & 0 & 0 & 0 & $-0.230^{* * *}$ & 0 & 0 & 0 & 0 & 0 \\
\hline & c & c & c & c & $(0.066)$ & c & c & c & c & c \\
\hline \multirow[t]{2}{*}{ ECM } & $-0.589^{* * *}$ & $-0.377^{* * *}$ & $-0.104^{*}$ & $-0.215^{* * *}$ & $-0.384^{\star * *}$ & $-0.394^{* * *}$ & $-0.245^{\star * *}$ & $-0.202^{* * *}$ & $-0.215^{\star * *}$ & $-0.202^{* * *}$ \\
\hline & $(0.103)$ & $(0.076)$ & $(0.059)$ & $(0.032)$ & $(0.101)$ & $(0.089)$ & $(0.046)$ & $(0.032)$ & $(0.032)$ & $(0.032)$ \\
\hline $\mathrm{R}^{2}$ & 0.737 & 0.566 & 0.490 & 0.479 & 0.669 & 0.728 & 0.747 & 0.442 & 0.789 & 0.866 \\
\hline F-test (p-value) & 0.28 & - & - & 0.27 & - & - & 0.98 & 0.03 & 0.97 & 0.55 \\
\hline Observations & 100 & 100 & 100 & 68 & 100 & 100 & 100 & 80 & 68 & 88 \\
\hline
\end{tabular}




\begin{tabular}{|c|c|c|c|c|c|c|c|c|c|c|c|}
\hline & IND & IRL & ISL & $\mid \mathbf{I S |}$ & & ITA & JPN & KOR & LUX & MEX & NLD \\
\hline Groups & & G6 & G10 & G1 & & & & & G6 & & G4 \\
\hline \multirow[t]{2}{*}{ Sample } & $1987 q 3$ & $1987 q^{3}$ & $1987 q 3$ & \multicolumn{2}{|c|}{$1995 q 3$} & $1987 q 3$ & $1987 q 3$ & $1987 q 3$ & $1987 q^{3}$ & $1987 q 3$ & $1987 q^{3}$ \\
\hline & $2012 q 2$ & $2012 q 2$ & $2012 q 2$ & \multicolumn{2}{|c|}{$2012 q 2$} & $2012 q 2$ & $2012 q 2$ & $2012 q 2$ & $2012 q 2$ & $2012 q 2$ & $2012 q 2$ \\
\hline \multicolumn{12}{|l|}{ LONG RUN } \\
\hline \multirow[t]{2}{*}{$\operatorname{lnXMKT}_{-1}$} & 1 & 1 & 1 & \multicolumn{2}{|c|}{1} & 1 & 1 & 1 & 1 & 1 & 1 \\
\hline & C & c & c & c & \multicolumn{2}{|r|}{ c } & $\mathrm{c}$ & c & c & C & C \\
\hline \multirow[t]{2}{*}{ InRPXGS $_{-1}$} & $-0.501^{* * *}$ & $-0.439^{* * *}$ & $-0.776^{* * *}$ & \multicolumn{2}{|c|}{$-0.776^{* * *}$} & $.794^{\star * *}$ & $0.758^{* * *}$ & 0.790 *** & $-0.439 * * *$ & $-1.373^{* * *}$ & -0.420 *** \\
\hline & $(0.156)$ & $(0.132)$ & $(0.233)$ & $(0.2$ & & $0.144)$ & $(0.118)$ & $(0.142)$ & $(0.132)$ & $(0.507)$ & $(0.095)$ \\
\hline SHORTRUN & & & & & & & & & & & \\
\hline$\Delta \ln X M K T$ & $0.902^{* * *}$ & $0.448^{* * *}$ & $0.622^{\star *}$ & 0.62 & & $.179^{* * *}$ & $1.323^{* * *}$ & $1.261^{* * *}$ & $0.448^{* * *}$ & $0.980^{\star * *}$ & $0.888^{* * *}$ \\
\hline & $(0.133)$ & $(0.058)$ & $(0.224)$ & $(0.2$ & & $0.137)$ & $(0.075)$ & (0.192) & $(0.058)$ & $(0.105)$ & $(0.043)$ \\
\hline$\triangle \operatorname{lnRPXGS}$ & $-0.294^{* * *}$ & $-0.114^{* * *}$ & $-0.410^{* *}$ & -0.41 & & $.264^{* * *}$ & $0.265^{* * *}$ & $0.376^{* * *}$ & $-0.114^{* * *}$ & $-0.763^{* * *}$ & $-0.140^{* * *}$ \\
\hline & $(0.089)$ & $(0.034)$ & $(0.167)$ & $(0.1$ & & $0.071)$ & $(0.046)$ & $(0.126)$ & $(0.034)$ & $(0.097)$ & $(0.042)$ \\
\hline$\Delta \ln X G_{S V} V_{-1}$ & 0 & 0 & $-0.430^{* *}$ & $* * *$ & & 0 & 0 & $-0.150^{*}$ & 0 & 0 & 0 \\
\hline & c & c & $(0.100)$ & ) & & c & c & (0.080) & c & c & c \\
\hline ECM & $-0.428^{* * *}$ & $-0.126^{* * *}$ & $-0.371^{\text {** }}$ & -0.37 & -0.2 & $.255^{* * *}$ & $0.213^{\star * *}$ & $0.344^{* * *}$ & $-0.126^{* * *}$ & $-0.149 * * *$ & $-0.245^{\star * *}$ \\
\hline & $(0.064)$ & $(0.024)$ & $(0.078)$ & $(0.0$ & & $0.046)$ & $(0.042)$ & (0.092) & $(0.024)$ & $(0.048)$ & $(0.046)$ \\
\hline $\mathrm{R}^{2}$ & 0.546 & 0.551 & 0.442 & 0.6 & & 0.779 & 0.911 & 0.618 & 0.703 & 0.777 & 0.702 \\
\hline F-test ( $p$-value) & - & 0.61 & 0.59 & 0.0 & & - & - & - & 0.01 & - & 0.79 \\
\hline Observations & 100 & 100 & 100 & 68 & & 100 & 100 & 100 & 100 & 100 & 100 \\
\hline & NOR & NZL & POL & PRT & RUS & SVK & SVN & SWE & TUR & USA & ZAF \\
\hline Groups & G6 & G6 & G10 & G7 & G2 & G7 & G7 & G3 & G7 & G5 & G1 \\
\hline Sample & $1987 q 3$ & $1987 q 3$ & 1991q2 & $1987 q 3$ & $1995 q 3$ & $1993 q 3$ & $1996 q 3$ & $1987 q 3$ & $1987 q 3$ & $1987 q 3$ & $1987 q 3$ \\
\hline & $2012 q 2$ & $2012 q 2$ & $2012 q 2$ & $2012 q 2$ & $2012 q 2$ & $2012 q 2$ & $2012 q 2$ & $2012 q 2$ & $2012 q 2$ & $2012 q 2$ & $2012 q 2$ \\
\hline LONG RUN & & & & & & & & & & & \\
\hline $\operatorname{InXMKT}_{-1}$ & 1 & 1 & 1 & 1 & 1 & 1 & 1 & 1 & 1 & 1 & 1 \\
\hline & $\mathrm{c}$ & c & c & c & c & c & c & c & c & c & $\mathrm{c}$ \\
\hline $\operatorname{InRPXGS}_{-1}$ & $-0.439^{\star \star \star}$ & $-0.439^{\star * *}$ & $-0.445^{\star *}$ & $-0.352^{\star *}$ & $-0.222^{\star \star *}$ & $-0.352^{* *}$ & $-0.352^{* *}$ & $-0.340^{* * *}$ & $-0.352^{\text {** }}$ & $-0.639^{\star * *}$ & $-0.201^{* * *}$ \\
\hline & $(0.132)$ & $(0.132)$ & $(0.189)$ & $(0.161)$ & $(0.0495)$ & $(0.161)$ & $(0.161)$ & $(0.095)$ & $(0.161)$ & $(0.210)$ & $(0.060)$ \\
\hline SHORTRUN & & & & & & & & & & & \\
\hline$\Delta \operatorname{lnXMKT}$ & $0.448^{* * *}$ & $0.448^{* * *}$ & $0.946^{\star \star *}$ & $1.109^{\star \star \star}$ & $0.831^{* * *}$ & $1.109^{\star * *}$ & $1.109^{* * *}$ & $0.664^{* * *}$ & $1.109^{* * *}$ & $0.778^{\star * *}$ & $0.750^{\star * *}$ \\
\hline & $(0.058)$ & $(0.058)$ & $(0.092)$ & $(0.084)$ & $(0.249)$ & $(0.084)$ & $(0.084)$ & $(0.068)$ & $(0.084)$ & $(0.061)$ & $(0.129)$ \\
\hline$\triangle \operatorname{lnRPXGS}$ & $-0.114^{\star \star \star}$ & $-0.114^{\star * *}$ & $-0.889^{* * *}$ & $-0.139^{\star *}$ & $-0.0832^{*}$ & $-0.139^{* *}$ & $-0.139^{* *}$ & $-0.0798^{* *}$ & $-0.139^{* *}$ & $-0.137^{* \star *}$ & $-0.432^{\star * *}$ \\
\hline & $(0.034)$ & $(0.034)$ & $(0.053)$ & $(0.057)$ & $(0.0496)$ & $(0.057)$ & $(0.057)$ & $(0.035)$ & $(0.057)$ & $(0.041)$ & $(0.092)$ \\
\hline$\Delta \ln X G S V_{-1}$ & $-0.346^{\star \star *}$ & $-0.239^{\star \star *}$ & 0 & 0 & 0 & 0 & 0 & $0.266^{* * *}$ & 0 & 0 & 0 \\
\hline & $(0.095)$ & $(0.077)$ & c & c & c & c & c & $(0.075)$ & c & c & c \\
\hline ECM & $-0.126^{* \star *}$ & $-0.126^{* \star *}$ & $-0.202^{\star \star *}$ & $-0.215^{\star \star *}$ & $-0.651^{* \star *}$ & $-0.215^{\star \star *}$ & $-0.215^{\star \star *}$ & $-0.217^{* * *}$ & $-0.215^{\star * *}$ & $-0.112^{\star * \star}$ & $-0.756^{* * *}$ \\
\hline & $(0.024)$ & $(0.024)$ & $(0.032)$ & $(0.032)$ & $(0.138)$ & $(0.032)$ & $(0.032)$ & $(0.044)$ & $(0.032)$ & $(0.031)$ & $(0.074)$ \\
\hline $\mathrm{R}^{2}$ & 0.330 & 0.347 & 0.874 & 0.431 & 0.542 & 0.721 & 0.788 & 0.711 & 0.444 & 0.833 & 0.645 \\
\hline F-test (p-value) & 0.49 & 0.22 & 0.26 & 0.13 & 0.69 & 0.60 & 0.04 & 0.83 & 0.46 & 0.55 & 0.88 \\
\hline Observations & 100 & 100 & 85 & 100 & 68 & 76 & 64 & 100 & 100 & 100 & 100 \\
\hline
\end{tabular}

Note: Robust standard errors in parentheses. ${ }^{*},{ }^{* *},{ }^{* *}$ denotes statistical significance at $10 \%, 5 \%, 1 \%$. 
Table A.3. Estimated import volume equations

\begin{tabular}{|c|c|c|c|c|c|c|c|c|c|c|c|}
\hline & ARG & AUS & AUT & BEL & BRA & CAN & CHE & $\mathrm{CHL}$ & CHN & CZE & DEU \\
\hline Groups & 4 & 2 & 8 & 4 & 3 & 5 & 4 & 3 & 7 & 6 & 8 \\
\hline \multirow[t]{2}{*}{ Sample } & $1993 q 3$ & $1987 q 3$ & $1987 q 3$ & $1987 q 3$ & $1996 q 3$ & $1987 q 3$ & $1987 q 3$ & $1996 q 2$ & $1994 q 2$ & $1991 q 3$ & $1987 q 3$ \\
\hline & $2012 q 2$ & $2012 q 2$ & $2012 q 2$ & $2012 q 2$ & $2012 q 2$ & $2012 q 2$ & $2012 q 2$ & $2012 q 2$ & $2010 q 4$ & $2012 q 2$ & $2012 q 2$ \\
\hline \multicolumn{12}{|l|}{ LONG RUN } \\
\hline \multirow[t]{2}{*}{$\operatorname{lnXGSV}_{-1}$} & $0.278^{\star \star *}$ & $0.183^{* * *}$ & $0.631^{\star * *}$ & $0.765^{\star \star \star}$ & $0.305^{\star \star *}$ & $0.360^{\star \star *}$ & $0.705^{\star \star *}$ & $0.353^{\star \star *}$ & $0.345^{\star \star \star}$ & $0.515^{\star \star *}$ & $0.664^{\star * *}$ \\
\hline & $(0.0161)$ & $(0.0218)$ & $(0.220)$ & $(0.145)$ & $(0.0215)$ & $(0.0811)$ & $(0.147)$ & $(0.0147)$ & $(0.0342)$ & $(0.0950)$ & $(0.167)$ \\
\hline \multirow[t]{2}{*}{$\operatorname{lnCPV}_{-1}$} & $0.923^{\star * *}$ & $0.660^{* * *}$ & $0.506^{\star * *}$ & $0.413^{* * *}$ & $1.015^{\star * *}$ & $0.516^{\star * *}$ & $0.658^{* * *}$ & $0.759^{\star * *}$ & & $0.282^{\star * *}$ & $0.670^{* * *}$ \\
\hline & $(0.0533)$ & $(0.0786)$ & $(0.177)$ & $(0.0783)$ & $(0.0717)$ & $(0.116)$ & $(0.137)$ & $(0.0315)$ & & $(0.0521)$ & $(0.169)$ \\
\hline \multirow[t]{2}{*}{$\operatorname{lnCGV}_{-1}$} & $0.0694^{\star \star \star}$ & $0.109^{\star * *}$ & $0.0698^{\star * *}$ & $0.0761^{\star \star *}$ & $0.127^{* * *}$ & $0.0762^{\star \star \star}$ & $0.0488^{\star * *}$ & $0.0728^{\star * *}$ & & $0.0457^{* * *}$ & $0.0889^{* * *}$ \\
\hline & $(0.00401)$ & $(0.0130)$ & $(0.0243)$ & $(0.0144)$ & $(0.00900)$ & $(0.0172)$ & $(0.0102)$ & $(0.00303)$ & & $(0.00843)$ & $(0.0224)$ \\
\hline \multirow[t]{2}{*}{ InITISKV } & $0.591^{\star \star *}$ & $0.418^{* * *}$ & $0.290^{\star * *}$ & $0.246^{* * *}$ & $0.545^{\star \star \star}$ & $0.303^{\star * *}$ & $0.327^{* \star *}$ & $0.385^{\star * *}$ & & $0.219^{* * *}$ & $0.301^{* * *}$ \\
\hline & $(0.0342)$ & $(0.0498)$ & $(0.101)$ & $(0.0466)$ & $(0.0385)$ & $(0.0683)$ & $(0.0679)$ & $(0.0160)$ & & $(0.0404)$ & $(0.0759)$ \\
\hline \multirow[t]{2}{*}{ InTDDV $_{-1}$} & & & & & & & & & $1.100^{\star * *}$ & & \\
\hline & & & & & & & & & (0.0999) & & \\
\hline \multirow[t]{2}{*}{ InRPMGS $_{-1}$} & $-0.151^{\star *}$ & $-0.520^{\star * *}$ & $-0.158^{* *}$ & $-0.151^{* *}$ & $-0.226^{\star * *}$ & 0 & $-0.151^{* *}$ & $-0.226^{\star \star *}$ & $-0.263^{\star * *}$ & $-0.406^{\star * *}$ & $-0.158^{\star *}$ \\
\hline & $(0.0680)$ & $(0.0995)$ & $(0.0777)$ & $(0.0680)$ & $(0.0432)$ & $\mathrm{C}$ & $(0.0680)$ & $(0.0432)$ & $(0.0718)$ & $(0.114)$ & $(0.0777)$ \\
\hline \multicolumn{12}{|l|}{ SHORT RUN } \\
\hline \multirow[t]{2}{*}{$\Delta \operatorname{lnXGSV}$} & $0.217^{\star \star *}$ & $0.0547^{* * *}$ & $0.617^{\star \star \star}$ & $0.694^{\star * *}$ & $0.202^{\star \star \star}$ & $0.504^{\star * \star}$ & $0.765^{\star \star \star}$ & $0.284^{\star * *}$ & $1.267^{\star * *}$ & $0.840^{* * *}$ & $0.545^{\star \star \star}$ \\
\hline & $(0.0145)$ & $(0.0207)$ & $(0.170)$ & $(0.0906)$ & $(0.0249)$ & $(0.0408)$ & $(0.0823)$ & $(0.0274)$ & $(0.151)$ & $(0.0481)$ & $(0.0922)$ \\
\hline \multirow[t]{2}{*}{$\Delta \operatorname{lnCPV}$} & $0.718^{\star \star \star}$ & $0.197^{\star * *}$ & $0.495^{\star * *}$ & $0.375^{\star \star *}$ & $0.672^{\star \star *}$ & $0.724^{* * *}$ & $0.714^{* * *}$ & $0.612^{* * *}$ & & $0.461^{\star * \star}$ & $0.550^{* * *}$ \\
\hline & $(0.0481)$ & $(0.0745)$ & $(0.136)$ & $(0.0489)$ & $(0.0828)$ & $(0.0586)$ & $(0.0768)$ & $(0.0591)$ & & $(0.0264)$ & $(0.0930)$ \\
\hline \multirow[t]{2}{*}{$\triangle \mathrm{InCGV}$} & $0.0540^{\star * *}$ & $0.0326^{* * *}$ & $0.0683^{\star * *}$ & $0.0691^{* * *}$ & $0.0843^{\star * *}$ & $0.107^{\star \star \star}$ & $0.0530^{* * *}$ & $0.0587^{\star \star *}$ & & $0.0745^{\star * *}$ & $0.0729^{* * *}$ \\
\hline & $(0.00362)$ & $(0.0123)$ & $(0.0188)$ & $(0.00902)$ & $(0.0104)$ & $(0.00865)$ & $(0.00570)$ & $(0.00566)$ & & $(0.00427)$ & $(0.0123)$ \\
\hline \multirow[t]{2}{*}{$\Delta$ InITISKV } & $0.460^{\star \star *}$ & $0.125^{\star \star *}$ & $0.283^{\star * *}$ & $0.223^{\star * *}$ & $0.360^{* * *}$ & $0.424^{\star * *}$ & $0.355^{\star \star \star}$ & $0.310^{\star * \star}$ & & $0.357^{\star \star \star}$ & $0.247^{\star * \star}$ \\
\hline & $(0.0308)$ & $(0.0472)$ & $(0.0780)$ & $(0.0292)$ & $(0.0444)$ & $(0.0344)$ & $(0.0381)$ & $(0.0300)$ & & $(0.0204)$ & $(0.0418)$ \\
\hline \multirow[t]{2}{*}{ InTDDV $_{-1}$} & & & & & & & & & $1.724^{\star \star \star}$ & & \\
\hline & & & & & & & & & $(0.327)$ & & \\
\hline \multirow[t]{2}{*}{$\Delta$ InRPMGS } & $-0.228^{\star * *}$ & $-0.310^{\star * *}$ & $-0.565^{\star \star \star}$ & 0 & $-0.144^{* * *}$ & 0 & 0 & $-0.144^{\star \star \star}$ & $-0.389^{\star * *}$ & $-0.177^{\star * *}$ & $-0.215^{\star \star *}$ \\
\hline & $(0.0306)$ & $(0.0783)$ & $(0.0652)$ & C & $(0.0397)$ & c & c & $(0.0397)$ & $(0.146)$ & $(0.0570)$ & $(0.0465)$ \\
\hline \multirow[t]{2}{*}{$\Delta$ InMGSV } & $0.164^{\star \star \star}$ & $0.285^{\star \star \star}$ & $0.388^{\star *}$ & 0 & 0 & 0 & 0 & 0 & 0 & 0 & 0 \\
\hline & $(0.0387)$ & $(0.108)$ & $(0.190)$ & c & c & C & c & c & c & C & c \\
\hline \multirow[t]{2}{*}{ ECM } & $-0.248^{\star * \star}$ & $-0.599^{\star * *}$ & $-0.231^{* * *}$ & $-0.248^{\star \star *}$ & $-0.877^{\star * *}$ & $-0.170^{\star * *}$ & $-0.248^{\star * *}$ & $-0.877^{\star * \star}$ & $-0.275^{\star \star \star}$ & $-0.264^{\star \star *}$ & $-0.231^{\star * *}$ \\
\hline & $(0.0318)$ & $(0.0510)$ & $(0.0251)$ & $(0.0318)$ & $(0.0793)$ & $(0.0280)$ & $(0.0318)$ & $(0.0793)$ & $(0.0290)$ & $(0.0298)$ & $(0.0251)$ \\
\hline $\mathrm{R}^{2}$ & 0.91 & 0.68 & 0.84 & 0.67 & 0.80 & 0.77 & 0.78 & 0.86 & 0.82 & 0.82 & 0.62 \\
\hline F-test (p-value) & 0.93 & 0.17 & 0.00 & 0.63 & 0.87 & 0.76 & 0.03 & 0.35 & 0.05 & 1.00 & 0.00 \\
\hline Observations & 76 & 100 & 100 & 100 & 64 & 100 & 100 & 65 & 67 & 84 & 100 \\
\hline
\end{tabular}




\begin{tabular}{|c|c|c|c|c|c|c|c|c|c|c|}
\hline & DNK & ESP & EST & FIN & FRA & GBR & GRC & HUN & IDN & IND \\
\hline Groups & 6 & 9 & 8 & const. 6 & 1 & 1 & 4 & 9 & 7 & 2 \\
\hline \multirow[t]{2}{*}{ Sample } & $1987 q 3$ & $1987 q 3$ & $1995 q 3$ & $1987 q 3$ & $1987 q 3$ & $1987 q 3$ & $1992 q 3$ & $1995 q^{3}$ & $1990 q 3$ & $1997 q 3$ \\
\hline & $2012 q 2$ & $2012 q 2$ & $2012 q 2$ & $2012 q 2$ & $2012 q 2$ & $2012 q 2$ & $2012 q 2$ & $2012 q 2$ & $2012 q 2$ & $2011 q 4$ \\
\hline \multicolumn{11}{|l|}{ LONG RUN } \\
\hline \multirow[t]{2}{*}{$\operatorname{InXGSV}_{-1}$} & $0.662^{\star \star \star}$ & $0.414^{\star \star \star}$ & $0.743^{\star \star \star}$ & $0.535^{\star \star *}$ & $0.550^{\star \star *}$ & $0.285^{\star \star \star}$ & $0.230^{\star \star *}$ & $0.536^{\star \star *}$ & $0.469^{\star \star *}$ & $0.328^{\star \star *}$ \\
\hline & $(0.0607)$ & $(0.0252)$ & $(0.0949)$ & $(0.115)$ & $(0.0869)$ & $(0.0361)$ & $(0.0260)$ & $(0.0525)$ & $(0.0543)$ & $(0.0255)$ \\
\hline \multirow[t]{2}{*}{$\operatorname{lnCPV}_{-1}$} & $0.513^{\star \star * *}$ & $0.629^{\star * * *}$ & $0.426^{\star * *}$ & $0.413^{\star * *}$ & $0.851^{\text {*** }}$ & $0.858^{\star * * *}$ & $0.589^{\star * * *}$ & $0.226^{\star * *}$ & $0.813^{\star * * *}$ & $0.587^{\star * *}$ \\
\hline & $(0.0470)$ & $(0.0382)$ & $(0.0544)$ & $(0.0892)$ & $(0.134)$ & $(0.109)$ & $(0.0665)$ & $(0.0222)$ & $(0.0942)$ & $(0.0456)$ \\
\hline \multirow[t]{2}{*}{$\operatorname{InCGV}_{-1}$} & $0.113^{* * *}$ & $0.0868^{\star * *}$ & $0.0555^{\star * *}$ & $0.0610^{* \star *}$ & $0.143^{\star * *}$ & $0.153^{* * *}$ & $0.0613^{\star * *}$ & $0.0374^{\star * *}$ & $0.0584^{\star * *}$ & $0.0438^{\star \star *}$ \\
\hline & $(0.0103)$ & (0.00528) & (0.00709) & $(0.0132)$ & $(0.0226)$ & $(0.0194)$ & $(0.00692)$ & $(0.00366)$ & $(0.00677)$ & $(0.00341)$ \\
\hline \multirow[t]{2}{*}{ InITISKV } & $0.291^{\star \star *}$ & $0.349^{* * *}$ & $0.330^{\star * \star *}$ & $0.190^{* * *}$ & $0.351^{* * *}$ & $0.278^{\star \star \star}$ & $0.242^{* \star *}$ & $0.108^{* * *}$ & $0.456^{* * *}$ & $0.672^{* \star *}$ \\
\hline & $(0.0266)$ & $(0.0212)$ & $(0.0421)$ & $(0.0411)$ & $(0.0554)$ & $(0.0352)$ & $(0.0273)$ & $(0.0106)$ & $(0.0529)$ & $(0.0522)$ \\
\hline \multirow[t]{2}{*}{ InRPMGS $_{-1}$} & $-0.406^{* * *}$ & $-0.164^{\star * *}$ & $-0.158^{\star *}$ & -0.406 & $-0.142^{\star *}$ & $-0.142^{\star *}$ & $-0.151^{* \star}$ & $-0.164^{\star * *}$ & $-0.263^{\star * *}$ & $-0.520^{\star * *}$ \\
\hline & $(0.114)$ & $(0.0370)$ & $(0.0777)$ & C & $(0.0654)$ & $(0.0654)$ & $(0.0680)$ & $(0.0370)$ & $(0.0718)$ & $(0.0995)$ \\
\hline \multicolumn{11}{|l|}{ SHORT RUN } \\
\hline \multirow[t]{2}{*}{$\Delta \operatorname{lnXGSV}$} & $0.405^{\star * *}$ & $0.714^{* * *}$ & $0.675^{\star * *}$ & $0.541^{* * *}$ & $0.549^{* * *}$ & $0.258^{* * *}$ & $0.218^{\star \star \star}$ & $0.753^{\star \star \star}$ & $0.242^{\star \star \star}$ & $0.110^{\star \star *}$ \\
\hline & $(0.0453)$ & $(0.0425)$ & $(0.0417)$ & $(0.0550)$ & $(0.0885)$ & $(0.0417)$ & $(0.0174)$ & $(0.0652)$ & $(0.0287)$ & $(0.0417)$ \\
\hline \multirow[t]{2}{*}{$\triangle \operatorname{lnCPV}$} & $0.314^{\star * *}$ & $1.086^{\star \star *}$ & $0.387^{\star * *}$ & $0.417^{\star * \star}$ & $0.850^{\star \star *}$ & $0.778^{* \star *}$ & $0.558^{\star * *}$ & $0.318^{\star * *}$ & $0.420^{* * *}$ & $0.197^{\star \star \star}$ \\
\hline & $(0.0351)$ & $(0.0646)$ & $(0.0239)$ & $(0.0425)$ & $(0.137)$ & $(0.126)$ & $(0.0447)$ & $(0.0275)$ & $(0.0498)$ & $(0.0745)$ \\
\hline \multirow[t]{2}{*}{$\Delta \mathrm{InCGV}$} & $0.0689^{\star \star *}$ & $0.150^{\star \star *}$ & $0.0505^{\star \star *}$ & $0.0616^{\star \star \star}$ & $0.143^{\star * *}$ & $0.139^{\star * \star}$ & $0.0581^{* * *}$ & $0.0525^{\star \star \star}$ & $0.0302^{\star \star \star}$ & $0.0147^{\star * *}$ \\
\hline & $(0.00770)$ & $(0.00891)$ & $(0.00312)$ & $(0.00627)$ & $(0.0230)$ & $(0.0224)$ & (0.00465) & $(0.00455)$ & $(0.00358)$ & $(0.00556)$ \\
\hline \multirow[t]{2}{*}{$\Delta$ InITISKV } & $0.178^{\star * *}$ & $0.603^{\star * *}$ & $0.300^{\star \star *}$ & $0.192^{\star * *}$ & $0.350^{\star * *}$ & $0.252^{* * *}$ & $0.229^{\star * *}$ & $0.152^{\star * *}$ & $0.236^{\star * *}$ & $0.225^{\star \star *}$ \\
\hline & (0.0199) & $(0.0359)$ & $(0.0185)$ & $(0.0196)$ & $(0.0564)$ & $(0.0407)$ & $(0.0184)$ & $(0.0132)$ & $(0.0280)$ & $(0.0852)$ \\
\hline \multirow[t]{2}{*}{$\triangle$ InRPMGS } & 0 & $-0.256^{* * *}$ & 0 & 0 & 0 & 0 & $-0.479^{* * *}$ & $-0.256^{* * *}$ & 0 & $-0.310^{* * *}$ \\
\hline & c & $(0.0527)$ & c & c & c & c & $(0.125)$ & $(0.0527)$ & c & $(0.0783)$ \\
\hline \multirow[t]{2}{*}{$\Delta \operatorname{lnMGSV}_{-1}$} & 0 & 0 & 0 & 0 & 0 & 0 & $0.118^{\star *}$ & 0 & $0.144^{\star * *}$ & $0.274^{\star * *}$ \\
\hline & c & c & c & c & c & c & $(0.0534)$ & c & $(0.0436)$ & $(0.0571)$ \\
\hline \multirow[t]{2}{*}{ ECM } & $-0.264^{\star * *}$ & $-0.532^{\star * *}$ & $-0.231^{* * *}$ & -0.264 & $-0.379^{\star * *}$ & $-0.379^{\star * *}$ & $-0.248^{\star * *}$ & $-0.532^{\star \star *}$ & $-0.275^{\star \star *}$ & $-0.599^{* * *}$ \\
\hline & $(0.0298)$ & $(0.0356)$ & $(0.0251)$ & C & $(0.0328)$ & $(0.0328)$ & $(0.0318)$ & $(0.0356)$ & $(0.0290)$ & $(0.0510)$ \\
\hline$R^{2}$ & 0.57 & 0.81 & 0.78 & 0.49 & 0.82 & 0.73 & 0.75 & 0.81 & 0.64 & 0.87 \\
\hline F-test (p-value) & 0.47 & 0.38 & 0.02 & 0.00 & 0.03 & 0.76 & 0.82 & 0.17 & 0.96 & 0.97 \\
\hline Observations & 100 & 100 & 68 & 100 & 100 & 100 & 80 & 68 & 88 & 58 \\
\hline
\end{tabular}




\begin{tabular}{|c|c|c|c|c|c|c|c|c|c|c|}
\hline & IRL & ISL & ISR & ITA & JPN & KOR & LUX & MEX & NLD & NOR \\
\hline Groups & 7 & 1 & 1 & 1 & 5 & 5 & 6 & 7 & 6 & 9 \\
\hline \multirow[t]{2}{*}{ Sample } & $1987 q 3$ & $1987 q 3$ & $1995 q 3$ & $1987 q 3$ & $1987 q 3$ & 1987q3 & $1987 q 3$ & $1987 q 3$ & $1987 q 3$ & $1987 q 3$ \\
\hline & $2012 q 2$ & $2012 q 2$ & $2012 q 2$ & $2012 q 2$ & $2012 q 2$ & $2012 q 2$ & $2012 q 2$ & $2012 q 2$ & $2012 q 2$ & $2012 q 2$ \\
\hline \multicolumn{11}{|l|}{ LONG RUN } \\
\hline \multirow[t]{2}{*}{$\operatorname{InXGSV}_{-1}$} & $0.592^{\star * *}$ & $0.455^{\star \star *}$ & $0.554^{\star * *}$ & $0.565^{\star \star *}$ & $0.428^{* * *}$ & $0.772^{\star \star *}$ & $1.008^{* * *}$ & $0.390^{\star * *}$ & $0.713^{* * *}$ & $0.302^{\star * *}$ \\
\hline & $(0.163)$ & $(0.0238)$ & $(0.0840)$ & $(0.0654)$ & (0.0758) & $(0.0907)$ & $(0.0889)$ & $(0.0813)$ & $(0.114)$ & $(0.0164)$ \\
\hline \multirow[t]{2}{*}{$\operatorname{lnCPV}_{-1}$} & $0.215^{\star * *}$ & $0.449^{* * *}$ & $0.604^{* * *}$ & $0.875^{\star * *}$ & $1.323^{\star * *}$ & $0.627^{\star \star *}$ & $0.144^{* * *}$ & $0.589^{* * *}$ & $0.367^{* \star *}$ & $0.430^{\text {*** }}$ \\
\hline & $(0.0590)$ & $(0.0235)$ & $(0.0916)$ & $(0.101)$ & $(0.234)$ & $(0.0736)$ & $(0.0127)$ & $(0.123)$ & $(0.0587)$ & $(0.0234)$ \\
\hline \multirow[t]{2}{*}{$\operatorname{lnCGV}_{-1}$} & $0.0335^{\star * *}$ & $0.0842^{\star * *}$ & $0.105^{\star \star *}$ & $0.120^{* * *}$ & $0.170^{* * *}$ & $0.0686^{\star * *}$ & $0.0277^{\star \star *}$ & $0.0374^{\star \star *}$ & $0.0826^{\star * *}$ & $0.110^{\star * *}$ \\
\hline & $(0.00920)$ & $(0.00441)$ & $(0.0159)$ & $(0.0139)$ & $(0.0301)$ & $(0.00806)$ & $(0.00244)$ & $(0.00781)$ & $(0.0132)$ & (0.00598) \\
\hline \multirow[t]{2}{*}{ InITISKV } & $0.0925^{\star \star *}$ & $0.314^{\star * *}$ & $0.278^{\star \star \star}$ & $0.357^{\star * *}$ & $0.659^{\star \star *}$ & $0.392^{* * *}$ & $0.114^{* * *}$ & $0.353^{\star * \star}$ & $0.213^{* * *}$ & $0.336^{\star * *}$ \\
\hline & $(0.0254)$ & $(0.0164)$ & $(0.0421)$ & $(0.0413)$ & $(0.117)$ & $(0.0461)$ & $(0.0100)$ & $(0.0738)$ & $(0.0341)$ & $(0.0183)$ \\
\hline \multirow[t]{2}{*}{ InRPMGS $_{-1}$} & $-0.263^{* * *}$ & $-0.142^{\star *}$ & $-0.142^{\star *}$ & $-0.142^{\star *}$ & 0 & 0 & $-0.406^{\star * *}$ & $-0.263^{\star * *}$ & $-0.406^{\star * *}$ & $-0.164^{\star * *}$ \\
\hline & $(0.0718)$ & $(0.0654)$ & $(0.0654)$ & $(0.0654)$ & c & c & $(0.114)$ & $(0.0718)$ & $(0.114)$ & $(0.0370)$ \\
\hline \multicolumn{11}{|l|}{ SHORT RUN } \\
\hline \multirow{2}{*}{$\Delta \ln X G S V$} & $0.587^{\star * \star}$ & $0.230^{\star * *}$ & $0.612^{\star \star *}$ & $0.547^{\star \star \star}$ & $0.268^{\star \star *}$ & $0.761^{\star \star *}$ & $1.118^{\star \star *}$ & $0.373^{\star \star *}$ & $0.778^{\star * *}$ & $0.289^{\star \star *}$ \\
\hline & $(0.135)$ & $(0.0303)$ & $(0.0558)$ & $(0.0621)$ & $(0.0247)$ & $(0.0391)$ & $(0.0849)$ & $(0.0537)$ & $(0.0870)$ & $(0.0208)$ \\
\hline \multirow[t]{2}{*}{$\Delta \mathrm{lnCPV}$} & $0.213^{* * *}$ & $0.226^{\star * *}$ & $0.668^{* * *}$ & $0.848^{* * *}$ & $0.829 * * *$ & $0.617^{\star * *}$ & $0.160^{* * *}$ & $0.564^{* * *}$ & $0.400^{* * *}$ & $0.411^{* * *}$ \\
\hline & $(0.0489)$ & $(0.0299)$ & $(0.0609)$ & $(0.0961)$ & $(0.0764)$ & $(0.0317)$ & $(0.0122)$ & $(0.0811)$ & $(0.0447)$ & $(0.0296)$ \\
\hline \multirow[t]{2}{*}{$\Delta \mathrm{InCGV}$} & $0.0332^{* \star *}$ & $0.0425^{\star \star *}$ & $0.116^{\star \star *}$ & $0.116^{\star \star \star}$ & $0.106^{\star \star \star}$ & $0.0676^{\star * *}$ & $0.0307^{\star \star *}$ & $0.0358^{\star \star *}$ & $0.0901^{* * *}$ & $0.105^{\star \star \star}$ \\
\hline & $(0.00762)$ & $(0.00560)$ & (0.0106) & $(0.0132)$ & $(0.00980)$ & $(0.00347)$ & $(0.00233)$ & $(0.00516)$ & (0.0101) & (0.00757) \\
\hline \multirow[t]{2}{*}{$\Delta$ InITISKV } & $0.0918^{* * *}$ & $0.158^{\star * *}$ & $0.307^{\star \star *}$ & $0.346^{\star \star \star}$ & $0.413^{\star * *}$ & $0.386^{\star * *}$ & $0.126^{\star * *}$ & $0.339^{* * *}$ & $0.232^{\star \star \star}$ & $0.321^{\star * *}$ \\
\hline & $(0.0211)$ & $(0.0209)$ & $(0.0280)$ & $(0.0392)$ & $(0.0381)$ & $(0.0199)$ & $(0.00959)$ & $(0.0487)$ & $(0.0260)$ & $(0.0231)$ \\
\hline \multirow[t]{2}{*}{$\triangle$ InRPMGS } & $-0.272^{\star \star \star}$ & $-0.617^{\star * *}$ & 0 & 0 & 0 & $-0.233^{\star * *}$ & $-0.177^{* * *}$ & $-0.272^{\star * *}$ & $-0.177^{\star * *}$ & $-0.391^{* * *}$ \\
\hline & $(0.0615)$ & $(0.0763)$ & C & C & $\mathrm{C}$ & $(0.0399)$ & $(0.0570)$ & $(0.0615)$ & $(0.0570)$ & $(0.0838)$ \\
\hline \multirow[t]{2}{*}{$\Delta_{\text {InMGSV }}$} & 0 & 0 & 0 & 0 & $0.213^{* * *}$ & 0 & 0 & 0 & 0 & 0 \\
\hline & C & C & C & C & $(0.0574)$ & C & C & c & c & C \\
\hline \multirow[t]{2}{*}{ ECM } & $-0.275^{\star \star *}$ & $-0.379^{* * *}$ & $-0.379^{* * *}$ & $-0.379^{* * *}$ & $-0.170^{* * *}$ & $-0.170^{* * *}$ & $-0.264^{* * *}$ & $-0.275^{\star \star *}$ & $-0.264^{\star \star *}$ & $-0.532^{\star \star *}$ \\
\hline & $(0.0290)$ & $(0.0328)$ & $(0.0328)$ & $(0.0328)$ & $(0.0280)$ & $(0.0280)$ & $(0.0298)$ & $(0.0290)$ & $(0.0298)$ & $(0.0356)$ \\
\hline $\mathrm{R}^{2}$ & 0.76 & 0.68 & 0.71 & 0.75 & 0.67 & 0.86 & 0.71 & 0.75 & 0.62 & 0.68 \\
\hline F-test ( $p$-value) & 0.00 & 0.63 & 0.98 & 0.61 & 0.00 & 0.51 & 0.95 & 0.61 & 0.77 & 0.38 \\
\hline Observations & 100 & 100 & 68 & 100 & 100 & 100 & 100 & 100 & 100 & 100 \\
\hline
\end{tabular}




\begin{tabular}{|c|c|c|c|c|c|c|c|c|c|c|}
\hline & NZL & POL & PRT & RUS & SVK & SVN & SWE & TUR & USA & ZAF \\
\hline Groups & 9 & 8 & 8 & 8 & 1 & 9 & 1 & 8 & 9 & 7 \\
\hline \multirow[t]{2}{*}{ Sample } & $1987 q 3$ & $1990 q 3$ & $1987 q 3$ & $1995 q^{3}$ & $1993 q 3$ & $1996 q 3$ & $1987 q 3$ & $1987 q 3$ & $1990 q 2$ & $1987 q 3$ \\
\hline & $2012 q 2$ & $2012 q 2$ & $2012 q 2$ & $2012 q 2$ & $2012 q 2$ & $2012 q 2$ & $2012 q 2$ & $2012 q 2$ & $2012 q 2$ & $2012 q 2$ \\
\hline \multicolumn{11}{|l|}{ LONG RUN } \\
\hline \multirow[t]{2}{*}{$\operatorname{InXGSV}_{-1}$} & $0.248^{* * *}$ & $0.505^{\star * *}$ & $0.408^{* * *}$ & $0.266^{\star * *}$ & $0.520^{* * *}$ & $0.597^{\star \star *}$ & $0.500^{\star * *}$ & $0.363^{* * *}$ & $0.227^{\star * *}$ & $0.177^{\star \star *}$ \\
\hline & (0.0122) & $(0.0701)$ & $(0.105)$ & $(0.0327)$ & $(0.0615)$ & $(0.0296)$ & $(0.0649)$ & $(0.0396)$ & $(0.0143)$ & (0.0335) \\
\hline \multirow[t]{2}{*}{$\operatorname{lnCPV}_{-1}$} & $0.699^{\star * *}$ & $0.513^{* * *}$ & $0.596^{\star * *}$ & $0.563^{\star \star *}$ & $0.279^{\star * *}$ & $0.377^{\star * *}$ & $0.408^{\star * *}$ & $0.678^{* * *}$ & $1.102^{\star * *}$ & $0.640^{* * *}$ \\
\hline & $(0.0344)$ & $(0.0712)$ & $(0.153)$ & $(0.0693)$ & $(0.0330)$ & $(0.0187)$ & $(0.0530)$ & $(0.0739)$ & $(0.0691)$ & $(0.121)$ \\
\hline \multirow[t]{2}{*}{$\operatorname{lnCGV}_{-1}$} & $0.0995^{\star * *}$ & $0.0586^{\star * *}$ & $0.0756^{\star \star *}$ & $0.108^{\star \star \star}$ & $0.0356^{* * *}$ & $0.0504^{* \star *}$ & $0.0912^{\star \star *}$ & $0.0404^{* * *}$ & $0.0998^{\star \star \star}$ & $0.0994^{\star * *}$ \\
\hline & $(0.00489)$ & $(0.00814)$ & $(0.0194)$ & $(0.0133)$ & $(0.00421)$ & $(0.00250)$ & $(0.0118)$ & $(0.00441)$ & $(0.00626)$ & $(0.0188)$ \\
\hline \multirow[t]{2}{*}{ InITISKV } & $0.349^{* * *}$ & $0.352^{\star * *}$ & $0.232^{\star * *}$ & $0.331^{* * *}$ & $0.181^{* * *}$ & $0.257^{* * *}$ & $0.226^{* * *}$ & $0.439^{* * *}$ & $0.389^{* * *}$ & $0.256^{* * *}$ \\
\hline & $(0.0171)$ & $(0.0488)$ & $(0.0595)$ & $(0.0407)$ & $(0.0214)$ & $(0.0127)$ & $(0.0293)$ & $(0.0478)$ & $(0.0244)$ & $(0.0483)$ \\
\hline \multirow[t]{2}{*}{ InRPMGS $_{-1}$} & $-0.164^{\star \star \star}$ & $-0.158^{\star *}$ & $-0.158^{\star *}$ & $-0.158^{\star *}$ & $-0.142^{\star *}$ & $-0.164^{\star * *}$ & $-0.142^{\star \star}$ & $-0.158^{\star *}$ & $-0.164^{\star \star \star}$ & $-0.263^{* * *}$ \\
\hline & $(0.0370)$ & $(0.0777)$ & $(0.0777)$ & $(0.0777)$ & $(0.0654)$ & $(0.0370)$ & $(0.0654)$ & $(0.0777)$ & $(0.0370)$ & $(0.0718)$ \\
\hline \multicolumn{11}{|l|}{ SHORT RUN } \\
\hline \multirow[t]{2}{*}{$\Delta \operatorname{lnXGSV}$} & $0.233^{* * *}$ & $0.572^{\star * *}$ & $0.605^{\star * *}$ & $0.132^{* * *}$ & $0.782^{\star * \star}$ & $0.846^{\star * *}$ & $0.525^{\star * *}$ & $0.354^{* * *}$ & $0.168^{* * *}$ & $0.0836^{* * *}$ \\
\hline & (0.0167) & $(0.0643)$ & $(0.0692)$ & $(0.0135)$ & $(0.0556)$ & $(0.0507)$ & $(0.0741)$ & $(0.0160)$ & $(0.0357)$ & $(0.0293)$ \\
\hline \multirow[t]{2}{*}{$\triangle \mathrm{InCPV}$} & $0.657^{\star * *}$ & $0.581^{* * *}$ & $0.883^{\star * *}$ & $0.279^{\star \star *}$ & $0.419^{* * *}$ & $0.535^{\star \star \star}$ & $0.429^{\star \star *}$ & $0.661^{* * *}$ & $0.815^{\star * *}$ & $0.302^{* * *}$ \\
\hline & $(0.0471)$ & $(0.0653)$ & $(0.101)$ & $(0.0285)$ & $(0.0298)$ & $(0.0320)$ & $(0.0605)$ & $(0.0299)$ & $(0.173)$ & $(0.106)$ \\
\hline \multirow[t]{2}{*}{$\triangle \mathrm{lnCGV}$} & $0.0934^{\star * *}$ & $0.0664^{* * *}$ & $0.112^{\star \star \star}$ & $0.0534^{\star * *}$ & $0.0534^{* * *}$ & $0.0714^{\star \star \star}$ & $0.0957^{\star \star *}$ & $0.0394^{\star \star *}$ & $0.0738^{\star * *}$ & $0.0469^{\star \star *}$ \\
\hline & $(0.00671)$ & $(0.00747)$ & $(0.0128)$ & $(0.00547)$ & $(0.00380)$ & (0.00428) & $(0.0135)$ & $(0.00178)$ & $(0.0157)$ & $(0.0164)$ \\
\hline \multirow[t]{2}{*}{$\Delta$ InITISKV } & $0.327^{* * *}$ & $0.399^{* * *}$ & $0.343^{\star * *}$ & $0.164^{* * *}$ & $0.272^{\star \star *}$ & $0.364^{\star * *}$ & $0.238^{\star * *}$ & $0.428^{* * *}$ & $0.288^{\star * *}$ & $0.121^{* * *}$ \\
\hline & $(0.0235)$ & $(0.0448)$ & $(0.0392)$ & $(0.0168)$ & $(0.0194)$ & $(0.0218)$ & $(0.0335)$ & $(0.0194)$ & $(0.0612)$ & $(0.0422)$ \\
\hline \multirow[t]{2}{*}{$\Delta$ InRPMGS } & 0 & $-0.565^{\star \star \star}$ & 0 & $-0.323^{\star \star *}$ & $-0.961^{\star \star *}$ & $-0.338^{\star *}$ & 0 & $-0.215^{\star \star \star}$ & $-0.256^{\star \star *}$ & 0 \\
\hline & c & $(0.0652)$ & c & $(0.0624)$ & $(0.0869)$ & $(0.159)$ & c & $(0.0465)$ & $(0.0527)$ & c \\
\hline \multirow[t]{2}{*}{$\Delta$ InMGSV $_{-1}$} & 0 & 0 & 0 & 0 & 0 & 0 & 0 & 0 & $0.269^{* *}$ & 0 \\
\hline & c & c & c & c & c & c & c & c & $(0.107)$ & c \\
\hline \multirow[t]{2}{*}{ ECM } & $-0.532^{* * *}$ & $-0.231^{* * *}$ & $-0.231^{* * *}$ & $-0.231^{* * *}$ & $-0.379^{* * *}$ & $-0.532^{\star * *}$ & $-0.379^{* * *}$ & $-0.231^{* * *}$ & $-0.532^{* * *}$ & $-0.275^{\star * *}$ \\
\hline & $(0.0356)$ & $(0.0251)$ & $(0.0251)$ & $(0.0251)$ & $(0.0328)$ & $(0.0356)$ & $(0.0328)$ & $(0.0251)$ & $(0.0356)$ & $(0.0290)$ \\
\hline$R^{2}$ & 0.78 & 0.64 & 0.83 & 0.86 & 0.71 & 0.92 & 0.73 & 0.82 & 0.87 & 0.40 \\
\hline F-test ( $p$-value) & 0.98 & 0.03 & 0.01 & 0.27 & 0.78 & 0.61 & 0.48 & 0.23 & 0.05 & 0.20 \\
\hline Observations & 100 & 88 & 100 & 68 & 76 & 64 & 100 & 100 & 89 & 100 \\
\hline
\end{tabular}

Note: Robust standard errors in parentheses. ${ }^{*},{ }^{* *},{ }^{* * *}$ denotes statistical significance at $10 \%, 5 \%, 1 \%$. 
Table A.4. Estimated export price equations

\begin{tabular}{|c|c|c|c|c|c|c|c|c|c|c|}
\hline \multirow{2}{*}{ Groups } & \multirow[t]{2}{*}{ ARG } & \multirow[t]{2}{*}{ AUS } & \multicolumn{2}{|c|}{ AUT } & BEL & BRA & CAN & \multirow[t]{2}{*}{$\mathrm{CHE}$} & \multirow[t]{2}{*}{$\mathrm{CHL}$} & \multirow[t]{2}{*}{ CZE } \\
\hline & & & & & & G6 & & & & \\
\hline \multirow[t]{2}{*}{ Sample } & $1993 q 3$ & $1987 q 3$ & $1987 q 3$ & \multicolumn{2}{|c|}{ 1987q3 } & $1996 q 3$ & $1987 q 3$ & $1987 q^{3}$ & $1996 q 2$ & $1991 q 4$ \\
\hline & $2012 q 2$ & $2012 q 2$ & $2012 q 2$ & \multicolumn{2}{|c|}{$2012 q 2$} & $2012 q 2$ & $2012 q 2$ & $2012 q 2$ & $2012 q 2$ & $2012 q 2$ \\
\hline \multicolumn{11}{|l|}{ LONG RUN } \\
\hline \multirow[t]{2}{*}{$\operatorname{InPXCX}{ }_{-1}$} & $0.627^{* * *}$ & $0.404^{* * *}$ & 0.137 & 0.2 & & $0.801^{* * *}$ & $0.502^{* * *}$ & $0.286^{* *}$ & 0 & $0.406^{* * *}$ \\
\hline & $(0.071)$ & $(0.100)$ & $(0.06$ & $(0.1$ & & $(0.116)$ & $(0.118)$ & $(0.113)$ & c & $(0.036)$ \\
\hline InPTDD $_{-1}$ & $0.373^{* * *}$ & $0.596^{* * *}$ & 0.863 & 0.74 & *** & $0.199^{*}$ & $0.498^{* * *}$ & $0.714^{* * *}$ & 1 & $0.594^{* * *}$ \\
\hline & $(0.071)$ & $(0.100)$ & $(0.06$ & $(0.1$ & & $(0.116)$ & $(0.118)$ & $(0.113)$ & c & $(0.036)$ \\
\hline SHORTRUN & & & & & & & & & & \\
\hline$\triangle \operatorname{lnPXCX}$ & $0.768^{* * *}$ & $0.568^{* * *}$ & 0.101 & 0.17 & *** & $0.481^{* * *}$ & $0.148^{* * *}$ & $0.0775^{\star * *}$ & $0.140^{*}$ & $0.400^{* * *}$ \\
\hline & $(0.072)$ & $(0.046)$ & $(0.01$ & $(0.0$ & & $(0.075)$ & $(0.037)$ & $(0.017)$ & $(0.080)$ & $(0.055)$ \\
\hline$\Delta$ InPTDD & 0 & 0 & 0 & 0.40 & *** & 0 & 0 & 0 & 0 & 0 \\
\hline & c & c & C & $(0.1$ & & C & C & c & c & C \\
\hline$\triangle \operatorname{lnEXCH}$ & 0 & 0 & 0.0707 & 0.11 & $* * * *$ & $0.456^{* * *}$ & $0.366^{\star * *}$ & 0 & 0 & $0.0983^{* *}$ \\
\hline & C & c & (0.01 & $(0.0$ & & $(0.154)$ & $(0.072)$ & C & c & $(0.047)$ \\
\hline$\Delta \operatorname{lnPXGSX} X_{-1}$ & 0 & $0.325^{* * *}$ & 0 & 0.30 & *** & 0 & $0.133^{* *}$ & 0 & 0 & $0.149^{* *}$ \\
\hline & c & $(0.045)$ & C & $(0.0$ & & C & $(0.060)$ & c & c & $(0.074)$ \\
\hline ECM & $-0.472 * * *$ & $-0.436^{* * *}$ & -0.166 & -0.22 & $3^{* * *}$ & $0.348^{* * *}$ & $0.204^{* * *}$ & $-0.148 * *$ & $-0.267^{* * *}$ & $-0.796^{* * *}$ \\
\hline & $(0.097)$ & $(0.057)$ & $(0.04$ & $(0.0$ & & $(0.056)$ & $(0.050)$ & $(0.057)$ & $(0.082)$ & $(0.091)$ \\
\hline$\overline{\mathrm{R}^{2}}$ & 0.721 & 0.877 & 0.61 & 0.4 & & 0.786 & 0.779 & 0.375 & 0.630 & 0.758 \\
\hline F-test ( $p$-value) & - & - & - & - & & 0.49 & - & - & - & - \\
\hline Observations & 76 & 100 & 100 & 10 & & 64 & 100 & 100 & 65 & 83 \\
\hline & DEU & DNK & ESP & EST & FIN & FRA & GBR & GRC & HUN & IDN \\
\hline Groups & & & & & G2 & G3 & & G1 & & G6 \\
\hline Sample & $1987 q 3$ & $1987 q 3$ & $1987 q 3$ & $1995 q 3$ & $1987 q 3$ & $1987 q^{3}$ & $1987 q 3$ & $1992 q 3$ & $1995 q 3$ & $1990 q 3$ \\
\hline & $2012 q 2$ & $2012 q 2$ & $2012 q 2$ & $2012 q 2$ & $2012 q 2$ & $2012 q 2$ & $2012 q 2$ & $2012 q 2$ & $2012 q 2$ & $2012 q 2$ \\
\hline LONG RUN & & & & & & & & & & \\
\hline $\operatorname{InPXCX_{-1}}$ & $0.194^{* * *}$ & $0.204^{*}$ & $0.224^{* * *}$ & 0 & $0.344^{*}$ & $0.212^{*}$ & $0.460^{* * *}$ & $0.148^{*}$ & $0.574^{* * *}$ & $0.801^{* * *}$ \\
\hline & $(0.032)$ & $(0.116)$ & $(0.055)$ & c & $(0.177)$ & $(0.122)$ & $(0.075)$ & $(0.086)$ & $(0.065)$ & $(0.116)$ \\
\hline InPTDD & $0.806^{* * *}$ & $0.796^{* * *}$ & $0.776^{* * *}$ & 1 & $0.656^{* * *}$ & $0.788^{* * *}$ & $0.540 * * *$ & $0.852^{* * *}$ & $0.426^{* * *}$ & $0.199^{*}$ \\
\hline & $(0.032)$ & $(0.116)$ & $(0.055)$ & c & $(0.177)$ & $(0.122)$ & $(0.075)$ & $(0.086)$ & $(0.065)$ & $(0.116)$ \\
\hline SHORT RUN & & & & & & & & & & \\
\hline$\Delta \operatorname{lnPXCX}$ & $0.111^{* * *}$ & $0.253^{* * *}$ & $0.220^{* * *}$ & $0.315^{* * *}$ & $0.0533^{* *}$ & $0.125^{\star * *}$ & $0.211^{* * *}$ & $0.0945^{\star *}$ & $0.369^{* * *}$ & $0.481^{* * *}$ \\
\hline & $(0.015)$ & $(0.066)$ & $(0.043)$ & $(0.101)$ & $(0.027)$ & $(0.021)$ & $(0.021)$ & $(0.046)$ & $(0.034)$ & $(0.075)$ \\
\hline$\Delta$ InPTDD & $0.245^{\star *}$ & 0 & 0 & 0 & 0 & $0.572^{*}$ & 0 & 0 & 0 & 0 \\
\hline & $(0.108)$ & $\mathrm{c}$ & c & c & c & $(0.336)$ & c & c & c & c \\
\hline$\triangle \mathrm{InEXCH}$ & $0.0736^{* * *}$ & $0.180^{* * *}$ & $0.110 * * *$ & $0.225^{\star *}$ & 0 & $0.111^{* * *}$ & 0 & 0 & 0 & 0 \\
\hline & $(0.015)$ & $(0.054)$ & $(0.037)$ & $(0.087)$ & C & $(0.024)$ & c & c & c & c \\
\hline$\Delta \ln P X G S X_{-1}$ & 0 & $0.228^{* \star *}$ & 0 & 0 & -0 & 0 & 0 & $0.286^{* *}$ & 0 & 0 \\
\hline & c & $(0.071)$ & c & c & c & c & c & $(0.119)$ & c & c \\
\hline ECM & $-0.213^{* * *}$ & $-0.276^{* * *}$ & $-0.381^{* * *}$ & $-0.451^{* * *}$ & $-0.142^{* * *}$ & $-0.153^{* * *}$ & $-0.212^{* * *}$ & $-0.856^{* * *}$ & $-0.372^{* * *}$ & $-0.348^{* * *}$ \\
\hline & $(0.046)$ & $(0.046)$ & $(0.073)$ & $(0.069)$ & $(0.025)$ & $(0.034)$ & $(0.044)$ & $(0.042)$ & $(0.074)$ & $(0.056)$ \\
\hline $\mathrm{R}^{2}$ & 0.518 & 0.661 & 0.674 & 0.729 & 0.307 & 0.354 & 0.688 & 0.605 & 0.808 & 0.544 \\
\hline F-test (p-value) & - & - & - & - & 0.19 & 0.95 & - & 0.91 & - & 0.99 \\
\hline Observations & 100 & 100 & 100 & 68 & 100 & 100 & 100 & 80 & 68 & 88 \\
\hline
\end{tabular}




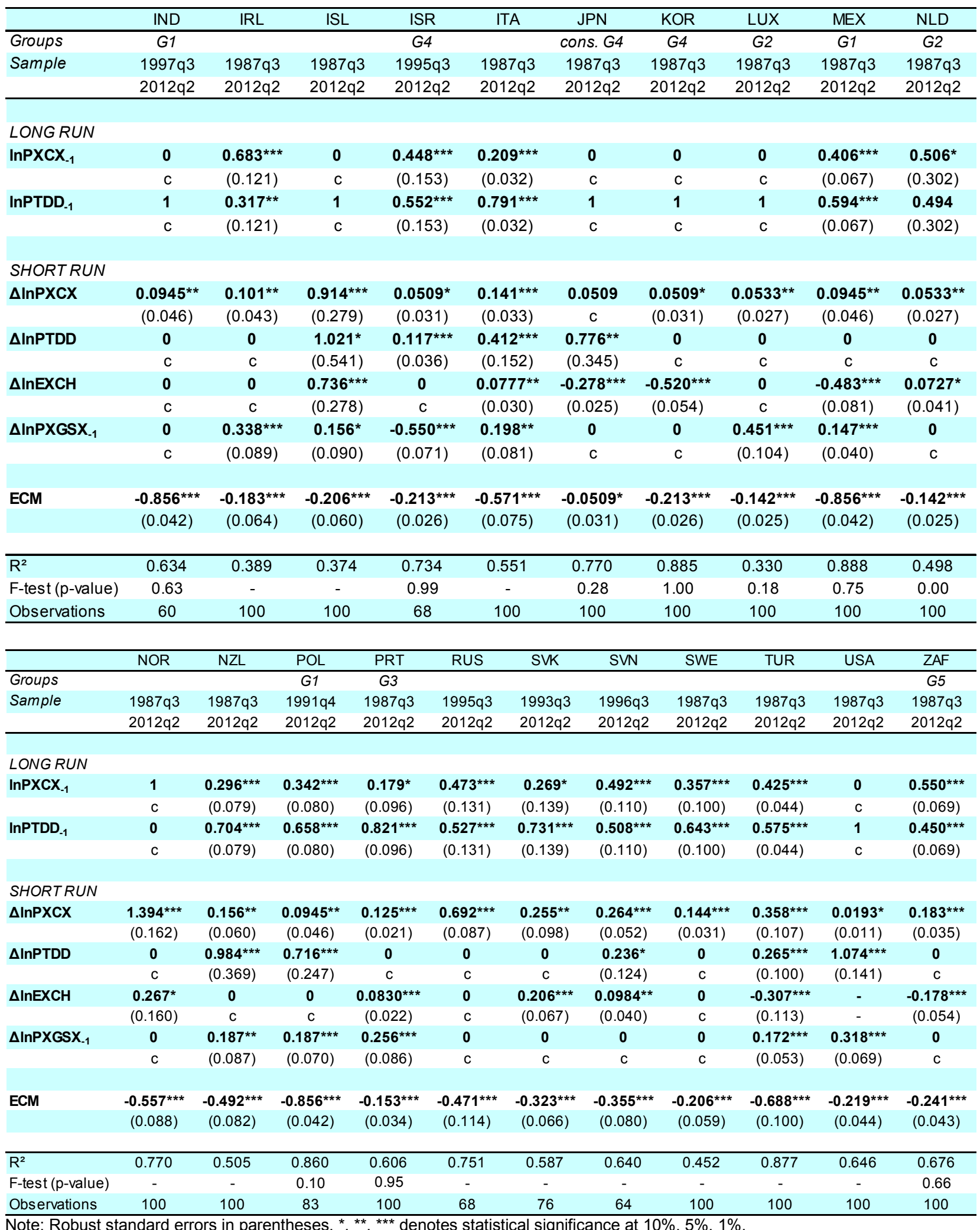


Table A.5. Estimated import price equations

\begin{tabular}{|c|c|c|c|c|c|c|c|c|c|c|}
\hline & ARG & AUS & AUT & $\mathrm{BE}$ & & BRA & CAN & $\mathrm{CHE}$ & $\mathrm{CHL}$ & CZE \\
\hline Groups & & G1 & G6 & & & & & & G2 & \\
\hline Sample & $1993 q 3$ & $1987 q 3$ & $1987 q$ & 1987 & q3 & $1996 q 3$ & $1987 q 3$ & $1987 q 3$ & $1996 q 2$ & $1991 q 4$ \\
\hline & $2012 q 2$ & $2012 q 2$ & $2012 q$ & 2012 & 2 2 & $2012 q 2$ & $2012 q 2$ & $2012 q 2$ & $2012 q 2$ & $2012 q 2$ \\
\hline LONG RUN & & & & & & & & & & \\
\hline InPMSHX & $0.929 * * *$ & $0.821^{* * *}$ & $0.592^{*}$ & 0.517 & $7 * * *$ & $0.912^{* * *}$ & $0.562 * * *$ & $0.683^{* * *}$ & $0.897^{* * *}$ & $0.657^{* * *}$ \\
\hline & $(0.031)$ & $(0.079)$ & $(0.245$ & $(0.08$ & 31) & $(0.035)$ & $(0.174)$ & $(0.071)$ & $(0.047)$ & $(0.033)$ \\
\hline InPTDD -1 & $0.0708^{* *}$ & $0.179 * *$ & 0.408 & 0.48 & $3^{* * *}$ & $.0882^{* *}$ & $0.438^{* *}$ & $0.317^{\star \star \star *}$ & $0.103^{* *}$ & $0.343^{* * *}$ \\
\hline & $(0.031)$ & $(0.079)$ & $(0.245$ & $(0.08$ & & $(0.035)$ & (0.174) & $(0.071)$ & $(0.047)$ & $(0.033)$ \\
\hline SHORTRUN & & & & & & & & & & \\
\hline$\Delta$ InPMSHX & $0.615^{\star * *}$ & $0.644^{* * *}$ & $0.377^{*}$ & 0.49 & $5^{* * *}$ & $0.577^{* * *}$ & $0.201^{* * *}$ & $0.441^{* * *}$ & $0.669 * * *$ & $0.542^{* * *}$ \\
\hline & $(0.097)$ & $(0.023)$ & $(0.118$ & $(0.07$ & & $(0.083)$ & $(0.047)$ & $(0.071)$ & $(0.051)$ & $(0.049)$ \\
\hline$\triangle$ InPTDD & $0.619 * * *$ & $0.136^{*}$ & $0.171^{*}$ & 1.113 & $* * *$ & $0.404^{*}$ & $0.573^{* *}$ & $0.654^{\star * *}$ & $0.240 * * *$ & $0.468^{* * *}$ \\
\hline & $(0.124)$ & $(0.077)$ & $(0.051$ & $(0.16$ & & $(0.203)$ & $(0.262)$ & $(0.172)$ & $(0.088)$ & $(0.121)$ \\
\hline$\triangle \operatorname{lnEXCH}$ & $-0.275^{\star * *}$ & 0 & 0.0991 & 0.22 & *** & $0.318^{* * *}$ & $0.503^{* * *}$ & $0.105^{\star * *}$ & 0 & 0 \\
\hline & $(0.101)$ & c & $(0.039$ & $(0.03$ & & $(0.098)$ & $(0.060)$ & $(0.036)$ & c & c \\
\hline$\Delta \operatorname{lnPMGSX} X_{-1}$ & $0.0608^{*}$ & 0 & 0 & 0.20 & $* * *$ & 0 & 0 & 0 & 0 & 0 \\
\hline & $(0.031)$ & c & c & $(0.06$ & & c & c & c & c & c \\
\hline ECM & $-0.433^{* * *}$ & $-0.212^{* * *}$ & $-0.171^{x}$ & -0.30 & $8^{* * *}$ & $.693^{* \star *}$ & $0.126^{* *}$ & $-0.456^{* * *}$ & $-0.720 * * *$ & $-0.794^{\star * *}$ \\
\hline & $(0.104)$ & $(0.023)$ & $(0.026$ & $(0.05$ & & $(0.092)$ & (0.062) & $(0.072)$ & $(0.067)$ & $(0.114)$ \\
\hline $\mathrm{R}^{2}$ & 0.967 & 0.915 & 0.493 & $\overline{0.72}$ & & 0.948 & 0.891 & 0.641 & 0.922 & 0.759 \\
\hline F-test ( $p$-value) & - & 0.14 & 0.83 & - & & - & - & - & 0.98 & - \\
\hline Observations & 76 & 100 & 100 & 10 & & 64 & 100 & 100 & 65 & 83 \\
\hline & $\overline{D E U}$ & DNK & ESP & EST & FIN & FRA & GBR & GRC & HUN & IDN \\
\hline Groups & G1 & & & G7 & G6 & & G5 & & G2 & \\
\hline Sample & $1987 q 3$ & $1987 q 3$ & $1987 q 3$ & $1995 q 3$ & $1987 q 3$ & $1987 q 3$ & $1987 q 3$ & $1992 q 3$ & $1995 q 3$ & $1990 q 3$ \\
\hline & $2012 q 2$ & $2012 q 2$ & $2012 q 2$ & $2012 q 2$ & $2012 q 2$ & $2012 q 2$ & $2012 q 2$ & $2012 q 2$ & $2012 q 2$ & $2012 q 2$ \\
\hline LONG RUN & & & & & & & & & & \\
\hline InPMSHX & $0.695^{\star \star \star}$ & $0.490^{\star * *}$ & $0.703^{* * *}$ & $0.579^{* * *}$ & $0.330^{* * *}$ & $0.328^{* * *}$ & $0.750^{\star * *}$ & $0.367^{\star * *}$ & $0.627^{\star \star *}$ & 1 \\
\hline & $(0.131)$ & $(0.097)$ & $(0.094)$ & $(0.098)$ & $(0.119)$ & $(0.074)$ & $(0.085)$ & $(0.126)$ & $(0.064)$ & c \\
\hline InPTDD -1 & $0.305^{\star \star}$ & $0.510^{* \star *}$ & $0.297^{* \star *}$ & $0.421^{* * *}$ & $0.670^{\star * *}$ & $0.672^{* * *}$ & $0.250^{* * *}$ & $0.633^{* * *}$ & $0.373^{* * *}$ & 0 \\
\hline & $(0.131)$ & $(0.097)$ & $(0.094)$ & $(0.098)$ & $(0.119)$ & $(0.074)$ & $(0.085)$ & $(0.126)$ & $(0.064)$ & c \\
\hline SHORT RUN & & & & & & & & & & \\
\hline$\triangle$ InPMSHX & $0.756^{* * *}$ & $0.783^{* * *}$ & $0.323^{* * *}$ & $0.252^{* * *}$ & $0.316^{* * *}$ & $0.313^{* * *}$ & $0.356^{* * *}$ & $0.231^{* * *}$ & $0.541^{* * *}$ & $0.476^{* * *}$ \\
\hline & $(0.094)$ & $(0.099)$ & $(0.041)$ & $(0.085)$ & $(0.074)$ & $(0.044)$ & $(0.033)$ & $(0.063)$ & $(0.051)$ & $(0.055)$ \\
\hline$\Delta$ InPTDD & $0.136^{*}$ & $0.306^{*}$ & $1.731^{* \star *}$ & $0.158^{* *}$ & $0.171^{* \star *}$ & $1.025^{\star \star *}$ & $0.566^{\star * *}$ & $0.629 * * *$ & $0.240^{\star * *}$ & $0.520^{* * *}$ \\
\hline & $(0.077)$ & $(0.160)$ & $(0.294)$ & $(0.071)$ & $(0.051)$ & $(0.368)$ & $(0.108)$ & $(0.117)$ & $(0.088)$ & $(0.160)$ \\
\hline$\triangle \mathrm{InEXCH}$ & $0.226^{\star * *}$ & $0.296^{\star * *}$ & $0.123^{* * *}$ & 0 & $0.144^{\star * *}$ & $0.131^{* * *}$ & 0 & $0.136^{*}$ & 0 & 0 \\
\hline & $(0.042)$ & $(0.049)$ & $(0.036)$ & c & $(0.045)$ & $(0.026)$ & c & $(0.080)$ & c & c \\
\hline$\Delta \ln P M G S X_{-1}$ & $0.303^{* * *}$ & 0 & 0 & 0 & $0.153^{\star *}$ & $0.279^{* * *}$ & 0 & 0 & 0 & 0 \\
\hline & $(0.096)$ & c & c & c & $(0.073)$ & $(0.071)$ & c & c & c & c \\
\hline ECM & $-0.212^{\star * *}$ & $-0.397^{\star * *}$ & $-0.235^{\star * *}$ & $-0.210^{* * *}$ & $-0.171^{* * *}$ & $-0.384^{* * *}$ & $-0.275^{\star * *}$ & $-0.403^{* * *}$ & $-0.720^{* * *}$ & $-0.0732^{*}$ \\
\hline & $(0.023)$ & $(0.072)$ & $(0.054)$ & $(0.032)$ & $(0.026)$ & $(0.068)$ & $(0.038)$ & $(0.089)$ & $(0.067)$ & $(0.042)$ \\
\hline $\mathrm{R}^{2}$ & 0.833 & 0.551 & 0.759 & 0.543 & 0.612 & 0.644 & 0.694 & 0.549 & 0.914 & 0.755 \\
\hline F-test ( $p$-value) & 0.82 & - & - & 0.15 & 0.49 & - & 0.00 & - & 0.91 & - \\
\hline Observations & 100 & 100 & 100 & 68 & 100 & 100 & 100 & 80 & 68 & 88 \\
\hline
\end{tabular}




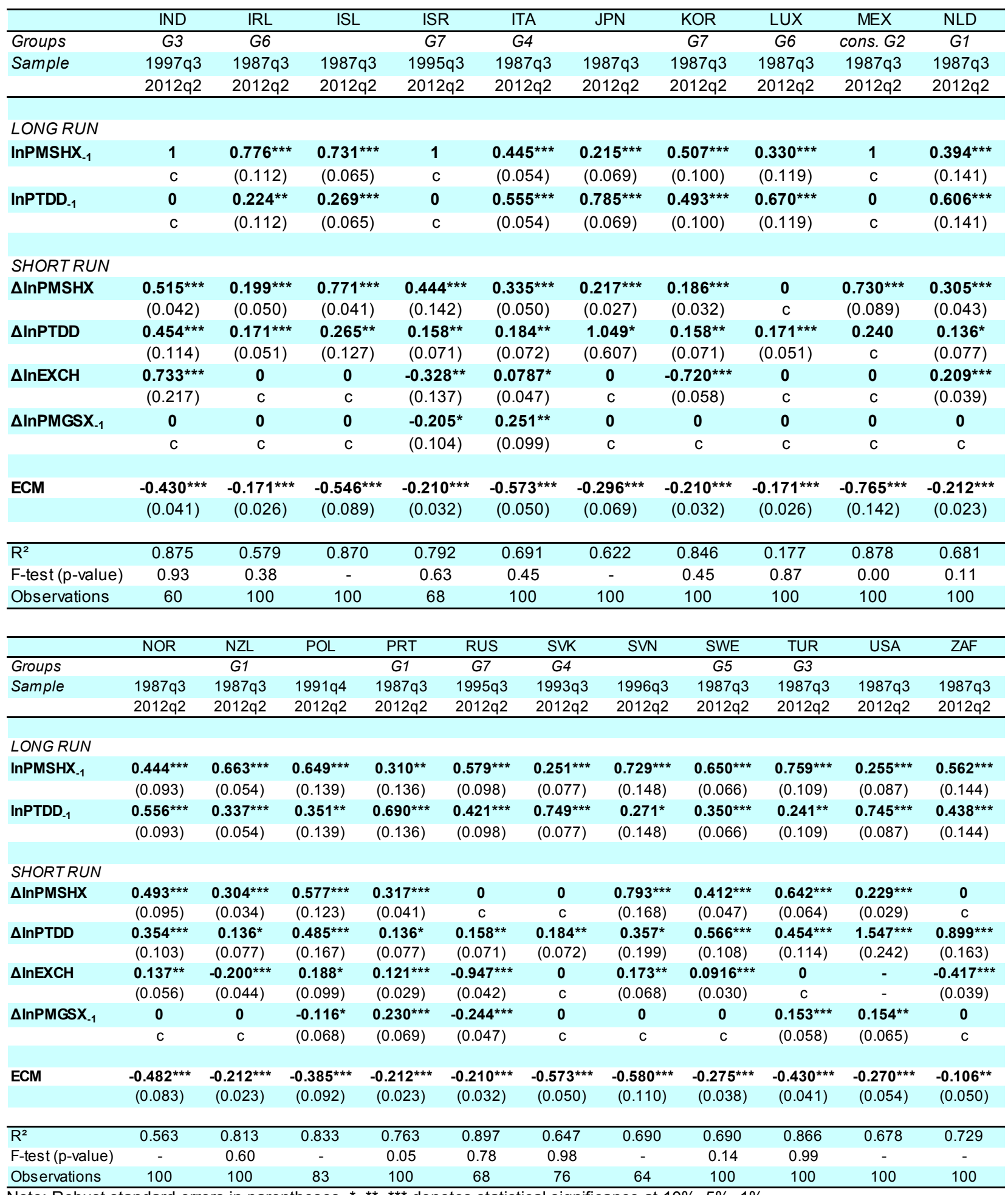

Note: Robust standard errors in parentheses. ${ }^{*},{ }^{* *},{ }^{* \star *}$ denotes statistical significance at $10 \%, 5 \%, 1 \%$. 
Table A.6. Estimated impulse-responses for export volumes

\begin{tabular}{|c|c|c|c|c|c|c|c|}
\hline \multirow{3}{*}{\begin{tabular}{|c|} 
Response \\
Impulse \\
Quarters \\
\end{tabular}} & \multicolumn{7}{|c|}{$\%$ change in XGSV } \\
\hline & \multicolumn{7}{|c|}{$1 \%$ increase in XMKT } \\
\hline & 1 & 2 & 4 & 8 & 20 & 40 & 70 \\
\hline ARG & 0.75 & 0.94 & 1.00 & 1.00 & 1.00 & 1.00 & 1.00 \\
\hline AUS & 0.75 & 0.84 & 0.93 & 0.99 & 1.00 & 1.00 & 1.00 \\
\hline AUT & 0.66 & 0.94 & 1.06 & 1.02 & 1.00 & 1.00 & 1.00 \\
\hline BEL & 0.45 & 0.61 & 0.75 & 0.88 & 0.99 & 1.00 & 1.00 \\
\hline BRA & 1.28 & 1.01 & 1.00 & 1.00 & 1.00 & 1.00 & 1.00 \\
\hline CAN & 0.84 & 0.90 & 0.96 & 0.99 & 1.00 & 1.00 & 1.00 \\
\hline $\mathrm{CHE}$ & 0.78 & 0.80 & 0.84 & 0.90 & 0.98 & 1.00 & 1.00 \\
\hline $\mathrm{CHL}$ & 0.33 & 0.87 & 1.00 & 1.00 & 1.00 & 1.00 & 1.00 \\
\hline $\mathrm{CHN}$ & 0.95 & 0.96 & 0.97 & 0.99 & 1.00 & 1.00 & 1.00 \\
\hline CZE & 1.11 & 1.09 & 1.05 & 1.02 & 1.00 & 1.00 & 1.00 \\
\hline DAE & 1.28 & 1.34 & 0.93 & 1.00 & 1.00 & 1.00 & 1.00 \\
\hline DEU & 0.93 & 0.97 & 1.00 & 1.00 & 1.00 & 1.00 & 1.00 \\
\hline DNK & 0.61 & 0.76 & 0.91 & 0.99 & 1.00 & 1.00 & 1.00 \\
\hline ESP & 0.74 & 0.77 & 0.82 & 0.88 & 0.97 & 1.00 & 1.00 \\
\hline EST & 1.11 & 1.09 & 1.05 & 1.02 & 1.00 & 1.00 & 1.00 \\
\hline FIN & 1.48 & 0.95 & 1.03 & 1.01 & 1.00 & 1.00 & 1.00 \\
\hline FRA & 0.89 & 0.93 & 0.98 & 1.00 & 1.00 & 1.00 & 1.00 \\
\hline GBR & 0.89 & 0.92 & 0.95 & 0.98 & 1.00 & 1.00 & 1.00 \\
\hline GRC & 0.95 & 0.96 & 0.97 & 0.99 & 1.00 & 1.00 & 1.00 \\
\hline HUN & 1.11 & 1.09 & 1.05 & 1.02 & 1.00 & 1.00 & 1.00 \\
\hline IDN & 0.95 & 0.96 & 0.97 & 0.99 & 1.00 & 1.00 & 1.00 \\
\hline IND & 0.90 & 0.94 & 0.98 & 1.00 & 1.00 & 1.00 & 1.00 \\
\hline IRL & 0.45 & 0.52 & 0.63 & 0.79 & 0.96 & 1.00 & 1.00 \\
\hline ISL & 0.62 & 0.49 & 0.73 & 0.92 & 1.00 & 1.00 & 1.00 \\
\hline ISR & 0.62 & 0.76 & 0.91 & 0.99 & 1.00 & 1.00 & 1.00 \\
\hline ITA & 1.18 & 1.13 & 1.07 & 1.02 & 1.00 & 1.00 & 1.00 \\
\hline JPN & 1.32 & 1.25 & 1.16 & 1.06 & 1.00 & 1.00 & 1.00 \\
\hline KOR & 1.26 & 0.98 & 1.01 & 1.00 & 1.00 & 1.00 & 1.00 \\
\hline LUX & 0.45 & 0.52 & 0.63 & 0.79 & 0.96 & 1.00 & 1.00 \\
\hline MEX & 0.98 & 0.98 & 0.99 & 0.99 & 1.00 & 1.00 & 1.00 \\
\hline NLD & 0.89 & 0.92 & 0.95 & 0.98 & 1.00 & 1.00 & 1.00 \\
\hline NOR & 0.45 & 0.36 & 0.50 & 0.67 & 0.90 & 0.98 & 1.00 \\
\hline NZL & 0.45 & 0.41 & 0.54 & 0.70 & 0.92 & 0.99 & 1.00 \\
\hline OIL & 0.25 & 0.52 & 0.97 & 1.20 & 0.99 & 1.00 & 1.00 \\
\hline $\mathrm{POL}$ & 0.95 & 0.96 & 0.97 & 0.99 & 1.00 & 1.00 & 1.00 \\
\hline PRT & 1.11 & 1.09 & 1.05 & 1.02 & 1.00 & 1.00 & 1.00 \\
\hline RUS & 0.93 & 0.97 & 1.00 & 1.00 & 1.00 & 1.00 & 1.00 \\
\hline SAU & 0.25 & 0.52 & 0.98 & 1.22 & 0.99 & 1.00 & 1.00 \\
\hline SVK & 1.11 & 1.09 & 1.05 & 1.02 & 1.00 & 1.00 & 1.00 \\
\hline SVN & 1.11 & 1.09 & 1.05 & 1.02 & 1.00 & 1.00 & 1.00 \\
\hline SWE & 0.66 & 0.91 & 1.02 & 1.01 & 1.00 & 1.00 & 1.00 \\
\hline TUR & 1.11 & 1.09 & 1.05 & 1.02 & 1.00 & 1.00 & 1.00 \\
\hline USA & 0.78 & 0.80 & 0.84 & 0.90 & 0.98 & 1.00 & 1.00 \\
\hline ZAF & 0.75 & 0.94 & 1.00 & 1.00 & 1.00 & 1.00 & 1.00 \\
\hline
\end{tabular}

\begin{tabular}{|c|c|c|c|c|c|c|c|}
\hline \multirow{3}{*}{\begin{tabular}{|c|} 
Response \\
Impulse \\
Quarters \\
\end{tabular}} & \multicolumn{7}{|c|}{$\%$ change in XGSV } \\
\hline & \multicolumn{7}{|c|}{$1 \%$ increase in RPXGS } \\
\hline & 1 & 2 & 4 & 8 & 20 & 40 & 70 \\
\hline ARG & -0.43 & -0.26 & -0.20 & -0.20 & -0.20 & -0.20 & -0.20 \\
\hline AUS & -0.23 & -0.45 & -0.67 & -0.80 & -0.83 & -0.83 & -0.83 \\
\hline AUT & -0.08 & -0.16 & -0.27 & -0.33 & -0.34 & -0.34 & -0.34 \\
\hline BEL & -0.11 & -0.18 & -0.26 & -0.35 & -0.42 & -0.43 & -0.43 \\
\hline BRA & -0.14 & -0.08 & -0.08 & -0.08 & -0.08 & -0.08 & -0.08 \\
\hline CAN & -0.17 & -0.33 & -0.51 & -0.60 & -0.62 & -0.62 & -0.62 \\
\hline CHE & -0.14 & -0.19 & -0.29 & -0.42 & -0.59 & -0.63 & -0.64 \\
\hline $\mathrm{CHL}$ & 0.19 & -0.10 & -0.16 & -0.16 & -0.16 & -0.16 & -0.16 \\
\hline $\mathrm{CHN}$ & -0.89 & -0.80 & -0.67 & -0.54 & -0.45 & -0.45 & -0.45 \\
\hline CZE & -0.14 & -0.18 & -0.25 & -0.31 & -0.35 & -0.35 & -0.35 \\
\hline DAE & -0.14 & -0.12 & -0.07 & -0.08 & -0.08 & -0.08 & -0.08 \\
\hline DEU & -0.10 & -0.17 & -0.21 & -0.22 & -0.22 & -0.22 & -0.22 \\
\hline DNK & -0.32 & -0.39 & -0.47 & -0.51 & -0.52 & -0.52 & -0.52 \\
\hline ESP & -0.13 & -0.25 & -0.46 & -0.75 & -1.14 & -1.27 & -1.29 \\
\hline EST & -0.14 & -0.18 & -0.25 & -0.31 & -0.35 & -0.35 & -0.35 \\
\hline FIN & -0.41 & -0.36 & -0.46 & -0.52 & -0.54 & -0.54 & -0.54 \\
\hline FRA & -0.10 & -0.18 & -0.25 & -0.29 & -0.29 & -0.29 & -0.29 \\
\hline GBR & -0.14 & -0.21 & -0.30 & -0.38 & -0.42 & -0.42 & -0.42 \\
\hline GRC & -0.89 & -0.80 & -0.67 & -0.54 & -0.45 & -0.45 & -0.45 \\
\hline HUN & -0.14 & -0.18 & -0.25 & -0.31 & -0.35 & -0.35 & -0.35 \\
\hline IDN & -0.89 & -0.80 & -0.67 & -0.54 & -0.45 & -0.45 & -0.45 \\
\hline IND & -0.29 & -0.38 & -0.46 & -0.50 & -0.50 & -0.50 & -0.50 \\
\hline IRL & -0.11 & -0.15 & -0.22 & -0.31 & -0.41 & -0.43 & -0.43 \\
\hline ISL & -0.41 & -0.37 & -0.55 & -0.70 & -0.77 & -0.78 & -0.78 \\
\hline ISR & -0.41 & -0.55 & -0.68 & -0.76 & -0.78 & -0.78 & -0.78 \\
\hline ITA & -0.26 & -0.40 & -0.58 & -0.73 & -0.79 & -0.79 & -0.79 \\
\hline JPN & -0.26 & -0.37 & -0.52 & -0.67 & -0.75 & -0.76 & -0.76 \\
\hline KOR & -0.38 & -0.46 & -0.63 & -0.75 & -0.79 & -0.79 & -0.79 \\
\hline LUX & -0.11 & -0.15 & -0.22 & -0.31 & -0.41 & -0.43 & -0.43 \\
\hline MEX & -0.76 & -0.85 & -1.00 & -1.18 & -1.34 & -1.37 & -1.37 \\
\hline NLD & -0.14 & -0.21 & -0.30 & -0.38 & -0.42 & -0.42 & -0.42 \\
\hline NOR & -0.11 & -0.11 & -0.18 & -0.26 & -0.38 & -0.42 & -0.43 \\
\hline NZZ & -0.11 & -0.13 & -0.19 & -0.27 & -0.39 & -0.43 & -0.43 \\
\hline OIL & -0.03 & -0.06 & -0.10 & -0.10 & -0.08 & -0.09 & -0.08 \\
\hline POL & -0.89 & -0.80 & -0.67 & -0.54 & -0.45 & -0.45 & -0.45 \\
\hline PRT & -0.14 & -0.18 & -0.25 & -0.31 & -0.35 & -0.35 & -0.35 \\
\hline RUS & -0.10 & -0.17 & -0.21 & -0.22 & -0.22 & -0.22 & -0.22 \\
\hline SAU & -0.03 & -0.06 & -0.10 & -0.11 & -0.08 & -0.09 & -0.08 \\
\hline SVK & -0.14 & -0.18 & -0.25 & -0.31 & -0.35 & -0.35 & -0.35 \\
\hline SVN & -0.14 & -0.18 & -0.25 & -0.31 & -0.35 & -0.35 & -0.35 \\
\hline SWE & -0.08 & -0.16 & -0.26 & -0.33 & -0.34 & -0.34 & -0.34 \\
\hline TUR & -0.14 & -0.18 & -0.25 & -0.31 & -0.35 & -0.35 & -0.35 \\
\hline USA & -0.14 & -0.19 & -0.29 & -0.42 & -0.59 & -0.63 & -0.64 \\
\hline ZAF & -0.43 & -0.26 & -0.20 & -0.20 & -0.20 & -0.20 & -0.20 \\
\hline
\end{tabular}


Table A.7. Estimated impulse-responses for import volumes

\begin{tabular}{|c|c|c|c|c|c|c|c|}
\hline Response & & & & ange in I & & & \\
\hline \begin{tabular}{l|} 
Impulse \\
\end{tabular} & & & $1 \%$ in & ease in & MGS & & \\
\hline Quarters & 1 & 2 & 4 & 8 & 20 & 40 & 70 \\
\hline ARG & -0.46 & -0.40 & -0.21 & -0.22 & -0.22 & -0.22 & -0.22 \\
\hline AUS & -0.17 & -0.19 & -0.15 & -0.14 & -0.14 & -0.14 & -0.14 \\
\hline AUT & -0.27 & -0.46 & -0.62 & -0.68 & -0.68 & -0.68 & -0.68 \\
\hline BEL & -0.11 & -0.19 & -0.29 & -0.34 & -0.34 & -0.34 & -0.34 \\
\hline BRA & -0.48 & -0.29 & -0.27 & -0.27 & -0.27 & -0.27 & -0.27 \\
\hline CAN & -0.18 & -0.22 & -0.29 & -0.35 & -0.39 & -0.40 & -0.40 \\
\hline CHE & -0.12 & -0.22 & -0.30 & -0.34 & -0.35 & -0.35 & -0.35 \\
\hline $\mathrm{CHL}$ & -0.16 & -0.17 & -0.17 & -0.17 & -0.17 & -0.17 & -0.17 \\
\hline CZE & -0.33 & -0.34 & -0.35 & -0.36 & -0.36 & -0.36 & -0.36 \\
\hline DEU & -0.19 & -0.24 & -0.32 & -0.40 & -0.46 & -0.47 & -0.47 \\
\hline DNK & -0.33 & -0.34 & -0.35 & -0.36 & -0.36 & -0.36 & -0.36 \\
\hline ESP & -0.19 & -0.24 & -0.32 & -0.40 & -0.46 & -0.47 & -0.47 \\
\hline EST & -0.19 & -0.27 & -0.35 & -0.43 & -0.47 & -0.47 & -0.47 \\
\hline FIN & -0.16 & -0.17 & -0.17 & -0.17 & -0.17 & -0.17 & -0.17 \\
\hline FRA & -0.19 & -0.24 & -0.32 & -0.40 & -0.46 & -0.47 & -0.47 \\
\hline GBR & -0.33 & -0.34 & -0.35 & -0.36 & -0.36 & -0.36 & -0.36 \\
\hline GRC & -0.17 & -0.18 & -0.15 & -0.14 & -0.14 & -0.14 & -0.14 \\
\hline HUN & -0.96 & -0.88 & -0.78 & -0.72 & -0.70 & -0.70 & -0.70 \\
\hline IDN & -0.65 & -0.70 & -0.60 & -0.59 & -0.59 & -0.59 & -0.59 \\
\hline IND & -0.92 & -0.86 & -0.82 & -0.81 & -0.81 & -0.81 & -0.81 \\
\hline IRL & -0.18 & -0.22 & -0.29 & -0.35 & -0.39 & -0.40 & -0.40 \\
\hline ISL & -0.16 & -0.17 & -0.17 & -0.17 & -0.17 & -0.17 & -0.17 \\
\hline ISR & -0.12 & -0.22 & -0.30 & -0.34 & -0.35 & -0.35 & -0.35 \\
\hline ITA & -0.17 & -0.16 & -0.15 & -0.14 & -0.14 & -0.14 & -0.14 \\
\hline JPN & -0.18 & -0.22 & -0.29 & -0.35 & -0.39 & -0.40 & -0.40 \\
\hline KOR & -0.18 & -0.20 & -0.26 & -0.33 & -0.39 & -0.40 & -0.40 \\
\hline LUX & -0.51 & -0.51 & -0.49 & -0.48 & -0.47 & -0.47 & -0.47 \\
\hline MEX & -0.33 & -0.34 & -0.35 & -0.36 & -0.36 & -0.36 & -0.36 \\
\hline NLD & -0.20 & -0.29 & -0.36 & -0.38 & -0.38 & -0.38 & -0.38 \\
\hline NOR & -0.16 & -0.17 & -0.17 & -0.17 & -0.17 & -0.17 & -0.17 \\
\hline NZL & -0.16 & -0.17 & -0.17 & -0.17 & -0.17 & -0.17 & -0.17 \\
\hline $\mathrm{POL}$ & -0.46 & -0.31 & -0.23 & -0.22 & -0.22 & -0.22 & -0.22 \\
\hline PRT & -0.12 & -0.15 & -0.17 & -0.19 & -0.19 & -0.19 & -0.19 \\
\hline RUS & -0.58 & -0.57 & -0.56 & -0.55 & -0.55 & -0.55 & -0.55 \\
\hline SVK & -0.33 & -0.34 & -0.35 & -0.36 & -0.36 & -0.36 & -0.36 \\
\hline SVN & -0.12 & -0.22 & -0.30 & -0.34 & -0.35 & -0.35 & -0.35 \\
\hline SWE & -0.17 & -0.18 & -0.15 & -0.14 & -0.14 & -0.14 & -0.14 \\
\hline TUR & -0.12 & -0.16 & -0.18 & -0.19 & -0.19 & -0.19 & -0.19 \\
\hline USA & -0.12 & -0.25 & -0.36 & -0.35 & -0.35 & -0.35 & -0.35 \\
\hline ZAF & -0.12 & -0.15 & -0.17 & -0.19 & -0.19 & -0.19 & -0.19 \\
\hline \begin{tabular}{|l|} 
Response \\
\end{tabular} & & & & ange in 1 & & & \\
\hline Impulse & & & & crease i & & & \\
\hline Quarters & 1 & 2 & 4 & 8 & 20 & 40 & 70 \\
\hline ARG & 0.85 & 1.21 & 1.18 & 1.14 & 1.14 & 1.14 & 1.14 \\
\hline AUS & 0.42 & 0.66 & 0.76 & 0.74 & 0.74 & 0.74 & 0.74 \\
\hline AUT & 0.51 & 0.64 & 0.61 & 0.53 & 0.52 & 0.52 & 0.52 \\
\hline BEL & 0.26 & 0.33 & 0.34 & 0.33 & 0.33 & 0.33 & 0.33 \\
\hline BRA & 0.79 & 1.10 & 1.14 & 1.14 & 1.14 & 1.14 & 1.14 \\
\hline CAN & 0.60 & 0.57 & 0.54 & 0.50 & 0.47 & 0.47 & 0.47 \\
\hline CHE & 0.58 & 0.57 & 0.56 & 0.55 & 0.55 & 0.55 & 0.55 \\
\hline $\mathrm{CHL}$ & 0.46 & 0.58 & 0.64 & 0.65 & 0.65 & 0.65 & 0.65 \\
\hline CZE & 0.36 & 0.33 & 0.29 & 0.26 & 0.25 & 0.25 & 0.25 \\
\hline DEU & 0.41 & 0.42 & 0.43 & 0.44 & 0.45 & 0.46 & 0.46 \\
\hline DNK & 0.23 & 0.29 & 0.38 & 0.46 & 0.49 & 0.49 & 0.49 \\
\hline ESP & 0.65 & 0.63 & 0.60 & 0.57 & 0.54 & 0.54 & 0.54 \\
\hline EST & 0.25 & 0.30 & 0.32 & 0.32 & 0.32 & 0.32 & 0.32 \\
\hline FIN & 0.29 & 0.38 & 0.42 & 0.43 & 0.43 & 0.43 & 0.43 \\
\hline FRA & 0.66 & 0.64 & 0.61 & 0.57 & 0.55 & 0.55 & 0.55 \\
\hline GBR & 0.60 & 0.61 & 0.63 & 0.65 & 0.66 & 0.66 & 0.66 \\
\hline GRC & 0.45 & 0.69 & 0.81 & 0.80 & 0.80 & 0.80 & 0.80 \\
\hline HUN & 0.28 & 0.28 & 0.28 & 0.28 & 0.28 & 0.28 & 0.28 \\
\hline IDN & 0.38 & 0.59 & 0.64 & 0.63 & 0.63 & 0.63 & 0.63 \\
\hline IND & 0.24 & 0.39 & 0.48 & 0.50 & 0.50 & 0.50 & 0.50 \\
\hline IRL & 0.20 & 0.22 & 0.25 & 0.28 & 0.29 & 0.30 & 0.30 \\
\hline ISL & 0.32 & 0.48 & 0.55 & 0.56 & 0.56 & 0.56 & 0.56 \\
\hline ISR & 0.53 & 0.56 & 0.59 & 0.60 & 0.60 & 0.60 & 0.60 \\
\hline ITA & 0.76 & 0.81 & 0.85 & 0.87 & 0.87 & 0.87 & 0.87 \\
\hline JPN & 0.53 & 0.63 & 0.76 & 0.91 & 1.01 & 1.01 & 1.01 \\
\hline KOR & 0.59 & 0.50 & 0.52 & 0.54 & 0.55 & 0.55 & 0.55 \\
\hline LUX & 0.10 & 0.11 & 0.13 & 0.15 & 0.16 & 0.17 & 0.17 \\
\hline MEX & 0.81 & 0.83 & 0.85 & 0.87 & 0.88 & 0.88 & 0.88 \\
\hline NLD & 0.31 & 0.29 & 0.28 & 0.28 & 0.28 & 0.28 & 0.28 \\
\hline NOR & 0.28 & 0.32 & 0.34 & 0.34 & 0.34 & 0.34 & 0.34 \\
\hline NZL & 0.48 & 0.53 & 0.55 & 0.55 & 0.55 & 0.55 & 0.55 \\
\hline $\mathrm{POL}$ & 0.75 & 0.70 & 0.67 & 0.67 & 0.67 & 0.67 & 0.67 \\
\hline PRT & 0.74 & 0.69 & 0.63 & 0.60 & 0.59 & 0.59 & 0.59 \\
\hline RUS & 0.27 & 0.35 & 0.43 & 0.48 & 0.49 & 0.49 & 0.49 \\
\hline SVK & 0.25 & 0.27 & 0.30 & 0.32 & 0.32 & 0.33 & 0.33 \\
\hline SVN & 0.43 & 0.39 & 0.35 & 0.33 & 0.33 & 0.33 & 0.33 \\
\hline SWE & 0.34 & 0.40 & 0.36 & 0.34 & 0.34 & 0.34 & 0.34 \\
\hline TUR & 0.72 & 0.80 & 0.77 & 0.75 & 0.75 & 0.75 & 0.75 \\
\hline USA & 0.62 & 0.90 & 0.95 & 0.88 & 0.88 & 0.88 & 0.88 \\
\hline ZAF & 0.21 & 0.49 & 0.76 & 0.91 & 0.93 & 0.93 & 0.93 \\
\hline
\end{tabular}

\begin{tabular}{|c|c|c|c|c|c|c|c|}
\hline \multirow{3}{*}{\begin{tabular}{|c|} 
Response \\
Impulse \\
Quarters \\
\end{tabular}} & \multicolumn{7}{|c|}{$\%$ change in MGSV } \\
\hline & & & & ease in & & & \\
\hline & 1 & 2 & 4 & 8 & 20 & 40 & 70 \\
\hline ARG & 0.17 & 0.24 & 0.24 & 0.23 & 0.23 & 0.23 & 0.23 \\
\hline AUS & 0.17 & 0.26 & 0.30 & 0.29 & 0.29 & 0.29 & 0.29 \\
\hline AUT & 0.53 & 0.67 & 0.63 & 0.55 & 0.54 & 0.54 & 0.54 \\
\hline BEL & 0.41 & 0.50 & 0.52 & 0.51 & 0.51 & 0.51 & 0.51 \\
\hline BRA & 0.16 & 0.22 & 0.23 & 0.23 & 0.23 & 0.23 & 0.23 \\
\hline CAN & 0.35 & 0.33 & 0.31 & 0.29 & 0.27 & 0.27 & 0.27 \\
\hline $\mathrm{CHE}$ & 0.52 & 0.51 & 0.50 & 0.49 & 0.49 & 0.49 & 0.49 \\
\hline $\mathrm{CHL}$ & 0.30 & 0.39 & 0.43 & 0.43 & 0.43 & 0.43 & 0.43 \\
\hline CZE & 0.55 & 0.51 & 0.45 & 0.40 & 0.37 & 0.37 & 0.37 \\
\hline DEU & 0.34 & 0.35 & 0.36 & 0.37 & 0.38 & 0.38 & 0.38 \\
\hline DNK & 0.24 & 0.32 & 0.41 & 0.49 & 0.53 & 0.53 & 0.53 \\
\hline ESP & 0.31 & 0.30 & 0.28 & 0.27 & 0.25 & 0.25 & 0.25 \\
\hline EST & 0.37 & 0.44 & 0.46 & 0.46 & 0.47 & 0.47 & 0.47 \\
\hline FIN & 0.27 & 0.35 & 0.39 & 0.39 & 0.39 & 0.39 & 0.39 \\
\hline FRA & 0.30 & 0.29 & 0.28 & 0.27 & 0.25 & 0.25 & 0.25 \\
\hline GBR & 0.28 & 0.29 & 0.30 & 0.31 & 0.31 & 0.31 & 0.31 \\
\hline GRC & 0.14 & 0.22 & 0.26 & 0.26 & 0.26 & 0.26 & 0.26 \\
\hline HUN & 0.47 & 0.47 & 0.47 & 0.47 & 0.47 & 0.47 & 0.47 \\
\hline IDN & 0.31 & 0.48 & 0.53 & 0.52 & 0.52 & 0.52 & 0.52 \\
\hline IND & 0.09 & 0.15 & 0.18 & 0.19 & 0.19 & 0.19 & 0.19 \\
\hline IRL & 0.40 & 0.43 & 0.49 & 0.54 & 0.58 & 0.58 & 0.58 \\
\hline ISL & 0.21 & 0.32 & 0.37 & 0.38 & 0.38 & 0.38 & 0.38 \\
\hline ISR & 0.40 & 0.43 & 0.45 & 0.46 & 0.46 & 0.46 & 0.46 \\
\hline ITA & 0.35 & 0.37 & 0.39 & 0.40 & 0.40 & 0.40 & 0.40 \\
\hline JPN & 0.14 & 0.17 & 0.21 & 0.25 & 0.27 & 0.27 & 0.27 \\
\hline KOR & 0.52 & 0.44 & 0.46 & 0.47 & 0.48 & 0.48 & 0.48 \\
\hline LUX & 0.51 & 0.57 & 0.65 & 0.75 & 0.82 & 0.83 & 0.83 \\
\hline MEX & 0.36 & 0.36 & 0.38 & 0.38 & 0.39 & 0.39 & 0.39 \\
\hline NLD & 0.50 & 0.47 & 0.46 & 0.45 & 0.45 & 0.45 & 0.45 \\
\hline NOR & 0.28 & 0.32 & 0.34 & 0.34 & 0.34 & 0.34 & 0.34 \\
\hline NZL & 0.25 & 0.27 & 0.28 & 0.28 & 0.28 & 0.28 & 0.28 \\
\hline $\mathrm{POL}$ & 0.49 & 0.46 & 0.44 & 0.44 & 0.44 & 0.44 & 0.44 \\
\hline PRT & 0.36 & 0.34 & 0.31 & 0.29 & 0.29 & 0.29 & 0.29 \\
\hline RUS & 0.18 & 0.24 & 0.29 & 0.33 & 0.33 & 0.33 & 0.33 \\
\hline SVK & 0.39 & 0.42 & 0.46 & 0.49 & 0.51 & 0.51 & 0.51 \\
\hline SVN & 0.57 & 0.51 & 0.46 & 0.44 & 0.44 & 0.44 & 0.44 \\
\hline SWE & 0.35 & 0.41 & 0.37 & 0.35 & 0.35 & 0.35 & 0.35 \\
\hline TUR & 0.26 & 0.29 & 0.28 & 0.27 & 0.27 & 0.27 & 0.27 \\
\hline USA & 0.11 & 0.15 & 0.16 & 0.15 & 0.15 & 0.15 & 0.15 \\
\hline ZAF & 0.08 & 0.19 & 0.30 & 0.36 & 0.37 & 0.37 & 0.37 \\
\hline Response & & & & nge in & & & \\
\hline \begin{tabular}{|l|} 
Impulse \\
\end{tabular} & & & & rease & & & \\
\hline Quarters & 1 & 2 & 4 & 8 & 20 & 40 & 70 \\
\hline ARG & 0.06 & 0.09 & 0.09 & 0.09 & 0.09 & 0.09 & 0.09 \\
\hline AUS & 0.06 & 0.09 & 0.10 & 0.10 & 0.10 & 0.10 & 0.10 \\
\hline AUT & 0.07 & 0.09 & 0.08 & 0.07 & 0.07 & 0.07 & 0.07 \\
\hline BEL & 0.05 & 0.06 & 0.06 & 0.06 & 0.06 & 0.06 & 0.06 \\
\hline BRA & 0.10 & 0.14 & 0.14 & 0.14 & 0.14 & 0.14 & 0.14 \\
\hline CAN & 0.09 & 0.08 & 0.08 & 0.07 & 0.07 & 0.07 & 0.07 \\
\hline $\mathrm{CHE}$ & 0.04 & 0.04 & 0.04 & 0.04 & 0.04 & 0.04 & 0.04 \\
\hline $\mathrm{CHL}$ & 0.04 & 0.04 & 0.05 & 0.05 & 0.05 & 0.05 & 0.05 \\
\hline CZE & 0.06 & 0.05 & 0.05 & 0.04 & 0.04 & 0.04 & 0.04 \\
\hline DEU & 0.05 & 0.06 & 0.06 & 0.06 & 0.06 & 0.06 & 0.06 \\
\hline DNK & 0.05 & 0.06 & 0.08 & 0.10 & 0.11 & 0.11 & 0.11 \\
\hline ESP & 0.09 & 0.09 & 0.08 & 0.08 & 0.07 & 0.07 & 0.07 \\
\hline EST & 0.03 & 0.04 & 0.04 & 0.04 & 0.04 & 0.04 & 0.04 \\
\hline FIN & 0.04 & 0.06 & 0.06 & 0.06 & 0.06 & 0.06 & 0.06 \\
\hline FRA & 0.11 & 0.11 & 0.10 & 0.10 & 0.09 & 0.09 & 0.09 \\
\hline GBR & 0.08 & 0.09 & 0.09 & 0.09 & 0.09 & 0.09 & 0.09 \\
\hline GRC & 0.05 & 0.07 & 0.08 & 0.08 & 0.08 & 0.08 & 0.08 \\
\hline HUN & 0.05 & 0.05 & 0.05 & 0.05 & 0.05 & 0.05 & 0.05 \\
\hline IDN & 0.02 & 0.03 & 0.04 & 0.04 & 0.04 & 0.04 & 0.04 \\
\hline IND & 0.02 & 0.03 & 0.04 & 0.04 & 0.04 & 0.04 & 0.04 \\
\hline $\mathbb{I R L}$ & 0.03 & 0.03 & 0.04 & 0.04 & 0.05 & 0.05 & 0.05 \\
\hline ISL & 0.06 & 0.09 & 0.10 & 0.11 & 0.11 & 0.11 & 0.11 \\
\hline ISR & 0.09 & 0.10 & 0.10 & 0.10 & 0.10 & 0.10 & 0.10 \\
\hline ITA & 0.10 & 0.11 & 0.12 & 0.12 & 0.12 & 0.12 & 0.12 \\
\hline JPN & 0.07 & 0.08 & 0.10 & 0.12 & 0.13 & 0.13 & 0.13 \\
\hline KOR & 0.06 & 0.05 & 0.06 & 0.06 & 0.06 & 0.06 & 0.06 \\
\hline LUX & 0.02 & 0.02 & 0.03 & 0.03 & 0.03 & 0.03 & 0.03 \\
\hline MEX & 0.05 & 0.05 & 0.05 & 0.06 & 0.06 & 0.06 & 0.06 \\
\hline NLD & 0.07 & 0.07 & 0.06 & 0.06 & 0.06 & 0.06 & 0.06 \\
\hline NOR & 0.06 & 0.07 & 0.07 & 0.07 & 0.07 & 0.07 & 0.07 \\
\hline NZI & 0.06 & 0.06 & 0.06 & 0.06 & 0.06 & 0.06 & 0.06 \\
\hline $\mathrm{POL}$ & 0.09 & 0.08 & 0.08 & 0.08 & 0.08 & 0.08 & 0.08 \\
\hline PRT & 0.09 & 0.09 & 0.08 & 0.08 & 0.08 & 0.08 & 0.08 \\
\hline RUS & 0.04 & 0.05 & 0.07 & 0.07 & 0.08 & 0.08 & 0.08 \\
\hline SVK & 0.03 & 0.03 & 0.04 & 0.04 & 0.04 & 0.04 & 0.04 \\
\hline SVN & 0.06 & 0.05 & 0.05 & 0.04 & 0.04 & 0.04 & 0.04 \\
\hline SWE & 0.08 & 0.09 & 0.08 & 0.08 & 0.08 & 0.08 & 0.08 \\
\hline TUR & 0.04 & 0.05 & 0.05 & 0.04 & 0.04 & 0.04 & 0.04 \\
\hline USA & 0.06 & 0.08 & 0.09 & 0.08 & 0.08 & 0.08 & 0.08 \\
\hline $\mathrm{ZAF}$ & 0.03 & 0.06 & 0.09 & 0.11 & 0.12 & 0.12 & 0.12 \\
\hline
\end{tabular}




\begin{tabular}{|c|c|c|c|c|c|c|c|}
\hline \multirow{3}{*}{\begin{tabular}{|l|l} 
Response \\
Impulse \\
Quarters \\
\end{tabular}} & \multicolumn{7}{|c|}{$\%$ change in MGSV } \\
\hline & \multicolumn{7}{|c|}{$1 \%$ increase in ITISKV } \\
\hline & 1 & 2 & 4 & 8 & 20 & 40 & 70 \\
\hline ARG & 0.58 & 0.81 & 0.80 & 0.77 & 0.77 & 0.77 & 0.77 \\
\hline AUS & 0.41 & 0.65 & 0.74 & 0.72 & 0.72 & 0.72 & 0.72 \\
\hline AUT & 0.42 & 0.53 & 0.50 & 0.43 & 0.43 & 0.43 & 0.43 \\
\hline BEL & 0.22 & 0.28 & 0.29 & 0.28 & 0.28 & 0.28 & 0.28 \\
\hline BRA & 0.45 & 0.62 & 0.64 & 0.64 & 0.64 & 0.64 & 0.64 \\
\hline CAN & 0.50 & 0.48 & 0.45 & 0.42 & 0.39 & 0.39 & 0.39 \\
\hline $\mathrm{CHE}$ & 0.41 & 0.40 & 0.39 & 0.39 & 0.39 & 0.39 & 0.39 \\
\hline $\mathrm{CHL}$ & 0.36 & 0.46 & 0.50 & 0.51 & 0.51 & 0.51 & 0.51 \\
\hline CZE & 0.40 & 0.37 & 0.33 & 0.29 & 0.27 & 0.27 & 0.27 \\
\hline DEU & 0.26 & 0.27 & 0.28 & 0.29 & 0.29 & 0.29 & 0.29 \\
\hline DNK & 0.18 & 0.24 & 0.31 & 0.37 & 0.40 & 0.40 & 0.40 \\
\hline ESP & 0.60 & 0.58 & 0.56 & 0.52 & 0.50 & 0.50 & 0.50 \\
\hline EST & 0.28 & 0.33 & 0.35 & 0.35 & 0.36 & 0.36 & 0.36 \\
\hline FIN & 0.22 & 0.29 & 0.32 & 0.33 & 0.33 & 0.33 & 0.33 \\
\hline FRA & 0.45 & 0.44 & 0.42 & 0.39 & 0.38 & 0.38 & 0.38 \\
\hline GBR & 0.30 & 0.31 & 0.32 & 0.33 & 0.33 & 0.33 & 0.33 \\
\hline GRC & 0.26 & 0.40 & 0.47 & 0.47 & 0.47 & 0.47 & 0.47 \\
\hline HUN & 0.22 & 0.22 & 0.22 & 0.22 & 0.22 & 0.22 & 0.22 \\
\hline IDN & 0.33 & 0.51 & 0.55 & 0.54 & 0.54 & 0.54 & 0.54 \\
\hline IND & 0.29 & 0.47 & 0.58 & 0.60 & 0.60 & 0.60 & 0.60 \\
\hline $\mathbb{I R L}$ & 0.15 & 0.16 & 0.18 & 0.20 & 0.21 & 0.21 & 0.21 \\
\hline ISL & 0.23 & 0.35 & 0.41 & 0.41 & 0.41 & 0.41 & 0.41 \\
\hline ISR & 0.35 & 0.37 & 0.39 & 0.40 & 0.40 & 0.40 & 0.40 \\
\hline ITA & 0.51 & 0.55 & 0.58 & 0.59 & 0.59 & 0.59 & $0.5 \mathrm{~s}$ \\
\hline JPN & 0.38 & 0.45 & 0.54 & 0.65 & 0.72 & 0.72 & 0.72 \\
\hline KOR & 0.62 & 0.52 & 0.55 & 0.56 & 0.57 & 0.57 & 0.57 \\
\hline LUX & 0.14 & 0.15 & 0.17 & 0.20 & 0.22 & 0.22 & 0.22 \\
\hline MEX & 0.51 & 0.52 & 0.54 & 0.55 & 0.56 & 0.56 & 0.56 \\
\hline NLD & 0.25 & 0.24 & 0.23 & 0.23 & 0.23 & 0.23 & 0.23 \\
\hline NOR & 0.34 & 0.38 & 0.41 & 0.41 & 0.41 & 0.41 & 0.41 \\
\hline NZL & 0.37 & 0.41 & 0.42 & 0.42 & 0.42 & 0.42 & 0.42 \\
\hline POL & 0.54 & 0.50 & 0.48 & 0.48 & 0.48 & 0.48 & 0.48 \\
\hline PRT & 0.48 & 0.44 & 0.41 & 0.39 & 0.39 & 0.39 & 0.39 \\
\hline RUS & 0.24 & 0.32 & 0.39 & 0.44 & 0.44 & 0.44 & 0.44 \\
\hline SVK & 0.24 & 0.25 & 0.27 & 0.29 & 0.30 & 0.30 & 0.30 \\
\hline SVN & 0.42 & 0.38 & 0.34 & 0.32 & 0.32 & 0.32 & 0.32 \\
\hline SWE & 0.27 & 0.32 & 0.29 & 0.27 & 0.27 & 0.27 & 0.27 \\
\hline TUR & 0.49 & 0.54 & 0.53 & 0.51 & 0.51 & 0.51 & 0.51 \\
\hline USA & 0.31 & 0.45 & 0.48 & 0.44 & 0.44 & 0.44 & 0.44 \\
\hline ZAF & 0.13 & 0.30 & 0.47 & 0.56 & 0.57 & 0.57 & 0.57 \\
\hline
\end{tabular}

\begin{tabular}{|c|c|c|c|c|c|c|c|}
\hline \multirow{3}{*}{\begin{tabular}{c|} 
Response \\
Impulse \\
Quarters \\
\end{tabular}} & \multicolumn{7}{|c|}{$\%$ change in MGSV } \\
\hline & \multicolumn{7}{|c|}{$1 \%$ increase in total expenditure } \\
\hline & 1 & 2 & 4 & 8 & 20 & 40 & 70 \\
\hline ARG & 1.67 & 2.35 & 2.30 & 2.22 & 2.22 & 2.22 & 2.22 \\
\hline AUS & 1.05 & 1.66 & 1.91 & 1.85 & 1.85 & 1.85 & 1.85 \\
\hline AUT & 1.54 & 1.93 & 1.83 & 1.59 & 1.56 & 1.56 & 1.56 \\
\hline BEL & 0.94 & 1.17 & 1.20 & 1.18 & 1.17 & 1.17 & 1.17 \\
\hline BRA & 1.50 & 2.09 & 2.15 & 2.15 & 2.15 & 2.15 & 2.15 \\
\hline CAN & 1.54 & 1.47 & 1.38 & 1.27 & 1.21 & 1.20 & 1.20 \\
\hline CHE & 1.55 & 1.52 & 1.49 & 1.47 & 1.47 & 1.47 & 1.47 \\
\hline $\mathrm{CHL}$ & 1.16 & 1.47 & 1.62 & 1.64 & 1.64 & 1.64 & 1.64 \\
\hline CZE & 1.37 & 1.26 & 1.11 & 0.99 & 0.93 & 0.93 & 0.93 \\
\hline DEU & 1.07 & 1.09 & 1.12 & 1.16 & 1.18 & 1.18 & 1.18 \\
\hline DNK & 0.70 & 0.91 & 1.19 & 1.43 & 1.53 & 1.53 & 1.53 \\
\hline ESP & 1.65 & 1.60 & 1.52 & 1.44 & 1.37 & 1.36 & 1.36 \\
\hline EST & 0.93 & 1.11 & 1.16 & 1.18 & 1.19 & 1.19 & 1.19 \\
\hline FIN & 0.83 & 1.08 & 1.20 & 1.21 & 1.21 & 1.21 & 1.21 \\
\hline FRA & 1.52 & 1.48 & 1.41 & 1.33 & 1.27 & 1.26 & 1.26 \\
\hline GBR & 1.26 & 1.30 & 1.34 & 1.38 & 1.40 & 1.40 & 1.40 \\
\hline GRC & 0.90 & 1.39 & 1.63 & 1.62 & 1.62 & 1.62 & 1.62 \\
\hline HUN & 1.01 & 1.01 & 1.01 & 1.01 & 1.01 & 1.01 & 1.01 \\
\hline IDN & 1.04 & 1.61 & 1.76 & 1.72 & 1.72 & 1.72 & 1.72 \\
\hline IND & 0.64 & 1.03 & 1.27 & 1.32 & 1.33 & 1.33 & 1.33 \\
\hline IRL & 0.78 & 0.85 & 0.95 & 1.06 & 1.13 & 1.14 & 1.14 \\
\hline ISL & 0.82 & 1.24 & 1.44 & 1.47 & 1.47 & 1.47 & 1.47 \\
\hline ISR & 1.37 & 1.45 & 1.53 & 1.56 & 1.57 & 1.57 & 1.57 \\
\hline ITA & 1.73 & 1.85 & 1.95 & 1.98 & 1.98 & 1.98 & 1.98 \\
\hline JPN & 1.12 & 1.32 & 1.61 & 1.92 & 2.12 & 2.14 & 2.14 \\
\hline KOR & 1.80 & 1.52 & 1.59 & 1.63 & 1.66 & 1.66 & 1.66 \\
\hline LUX & 0.77 & 0.86 & 0.98 & 1.12 & 1.23 & 1.24 & 1.24 \\
\hline MEX & 1.72 & 1.76 & 1.82 & 1.86 & 1.88 & 1.88 & 1.88 \\
\hline NLD & 1.13 & 1.07 & 1.03 & 1.02 & 1.02 & 1.02 & 1.02 \\
\hline NOR & 0.95 & 1.09 & 1.16 & 1.17 & 1.17 & 1.17 & 1.17 \\
\hline NZL & 1.16 & 1.26 & 1.31 & 1.32 & 1.32 & 1.32 & 1.32 \\
\hline $\mathrm{POL}$ & 1.87 & 1.74 & 1.67 & 1.66 & 1.66 & 1.66 & 1.66 \\
\hline PRT & 1.68 & 1.55 & 1.43 & 1.36 & 1.35 & 1.35 & 1.35 \\
\hline RUS & 0.73 & 0.95 & 1.19 & 1.32 & 1.34 & 1.34 & 1.34 \\
\hline SVK & 0.92 & 0.98 & 1.07 & 1.14 & 1.17 & 1.17 & 1.17 \\
\hline SVN & 1.47 & 1.33 & 1.20 & 1.14 & 1.13 & 1.13 & 1.13 \\
\hline SWE & 1.04 & 1.21 & 1.09 & 1.04 & 1.05 & 1.05 & 1.05 \\
\hline TUR & 1.52 & 1.68 & 1.62 & 1.58 & 1.58 & 1.58 & 1.58 \\
\hline USA & 1.09 & 1.59 & 1.68 & 1.55 & 1.55 & 1.55 & 1.55 \\
\hline ZAF & 0.44 & 1.04 & 1.63 & 1.94 & 1.99 & 1.99 & 1.99 \\
\hline
\end{tabular}


Table A.8. Estimated impulse-responses for export prices

\begin{tabular}{|c|c|c|c|c|c|c|c|}
\hline \multirow{3}{*}{\begin{tabular}{|c|} 
Response \\
Impulse \\
quarters \\
\end{tabular}} & \multicolumn{7}{|c|}{$\%$ change in PXGSX } \\
\hline & \multicolumn{7}{|c|}{$1 \%$ increase in PXCX } \\
\hline & 1 & 2 & 4 & 8 & 20 & 40 & 70 \\
\hline ARG & 0.77 & 0.70 & 0.65 & 0.63 & 0.63 & 0.63 & 0.63 \\
\hline AUS & 0.57 & 0.68 & 0.49 & 0.39 & 0.40 & 0.40 & 0.40 \\
\hline AUT & 0.10 & 0.11 & 0.12 & 0.13 & 0.14 & 0.14 & 0.14 \\
\hline BEL & 0.18 & 0.25 & 0.28 & 0.26 & 0.26 & 0.26 & 0.26 \\
\hline BRA & 0.48 & 0.59 & 0.71 & 0.79 & 0.80 & 0.80 & 0.80 \\
\hline CAN & 0.15 & 0.24 & 0.35 & 0.46 & 0.50 & 0.50 & 0.50 \\
\hline CHE & 0.08 & 0.11 & 0.16 & 0.22 & 0.28 & 0.29 & 0.29 \\
\hline $\mathrm{CHL}$ & 0.14 & 0.10 & 0.06 & 0.02 & 0.00 & 0.00 & 0.00 \\
\hline CZE & 0.40 & 0.46 & 0.41 & 0.41 & 0.41 & 0.41 & 0.41 \\
\hline DEU & 0.11 & 0.13 & 0.15 & 0.18 & 0.19 & 0.19 & 0.19 \\
\hline DNK & 0.25 & 0.30 & 0.26 & 0.21 & 0.20 & 0.20 & 0.20 \\
\hline ESP & 0.22 & 0.22 & 0.22 & 0.22 & 0.22 & 0.22 & 0.22 \\
\hline EST & 0.32 & 0.17 & 0.05 & 0.00 & 0.00 & 0.00 & 0.00 \\
\hline FIN & 0.05 & 0.09 & 0.16 & 0.24 & 0.33 & 0.34 & 0.34 \\
\hline FRA & 0.12 & 0.14 & 0.16 & 0.18 & 0.21 & 0.21 & 0.21 \\
\hline GBR & 0.21 & 0.26 & 0.34 & 0.41 & 0.46 & 0.46 & 0.46 \\
\hline GRC & 0.09 & 0.17 & 0.15 & 0.15 & 0.15 & 0.15 & 0.15 \\
\hline HUN & 0.37 & 0.45 & 0.52 & 0.57 & 0.57 & 0.57 & 0.57 \\
\hline IDN & 0.48 & 0.59 & 0.71 & 0.79 & 0.80 & 0.80 & 0.80 \\
\hline IND & 0.09 & 0.01 & 0.00 & 0.00 & 0.00 & 0.00 & 0.00 \\
\hline IRL & 0.10 & 0.24 & 0.47 & 0.65 & 0.68 & 0.68 & 0.68 \\
\hline ISL & 0.91 & 0.87 & 0.51 & 0.15 & 0.00 & 0.00 & 0.00 \\
\hline ISR & 0.05 & 0.14 & 0.25 & 0.37 & 0.44 & 0.45 & 0.45 \\
\hline ITA & 0.14 & 0.21 & 0.22 & 0.21 & 0.21 & 0.21 & 0.21 \\
\hline JPN & 0.05 & 0.05 & 0.04 & 0.04 & 0.02 & 0.01 & 0.00 \\
\hline KOR & 0.05 & 0.04 & 0.02 & 0.01 & 0.00 & 0.00 & 0.00 \\
\hline LUX & 0.05 & 0.07 & 0.06 & 0.01 & 0.00 & 0.00 & 0.00 \\
\hline MEX & 0.09 & 0.37 & 0.42 & 0.41 & 0.41 & 0.41 & 0.41 \\
\hline NLD & 0.05 & 0.12 & 0.22 & 0.35 & 0.48 & 0.51 & 0.51 \\
\hline NOR & 1.39 & 1.17 & 1.03 & 1.00 & 1.00 & 1.00 & 1.00 \\
\hline NZL & 0.16 & 0.25 & 0.30 & 0.30 & 0.30 & 0.30 & 0.30 \\
\hline POL & 0.09 & 0.32 & 0.36 & 0.34 & 0.34 & 0.34 & 0.34 \\
\hline PRT & 0.12 & 0.16 & 0.18 & 0.18 & 0.18 & 0.18 & 0.18 \\
\hline RUS & 0.69 & 0.59 & 0.51 & 0.48 & 0.47 & 0.47 & 0.47 \\
\hline SVK & 0.25 & 0.26 & 0.26 & 0.27 & 0.27 & 0.27 & 0.27 \\
\hline SVN & 0.26 & 0.35 & 0.43 & 0.48 & 0.49 & 0.49 & 0.49 \\
\hline SWE & 0.14 & 0.19 & 0.25 & 0.31 & 0.35 & 0.36 & 0.36 \\
\hline TUR & 0.36 & 0.47 & 0.43 & 0.42 & 0.42 & 0.42 & 0.42 \\
\hline USA & 0.02 & 0.02 & 0.01 & 0.00 & 0.00 & 0.00 & 0.00 \\
\hline ZAF & 0.18 & 0.27 & 0.39 & 0.50 & 0.55 & 0.55 & 0.55 \\
\hline
\end{tabular}

\begin{tabular}{|c|c|c|c|c|c|c|c|}
\hline \multirow{3}{*}{\begin{tabular}{|c|} 
Response \\
Impulse \\
quarters \\
\end{tabular}} & \multicolumn{7}{|c|}{$\%$ change in PXGSX } \\
\hline & \multicolumn{7}{|c|}{$1 \%$ increase in PTDD } \\
\hline & 1 & 2 & 4 & 8 & 20 & 40 & 70 \\
\hline ARG & 0.00 & 0.18 & 0.32 & 0.37 & 0.37 & 0.37 & 0.37 \\
\hline AUS & 0.00 & 0.26 & 0.61 & 0.60 & 0.60 & 0.60 & 0.60 \\
\hline AUT & 0.00 & 0.14 & 0.36 & 0.62 & 0.84 & 0.86 & 0.86 \\
\hline BEL & 0.40 & 0.60 & 0.73 & 0.74 & 0.74 & 0.74 & 0.74 \\
\hline BRA & 0.00 & 0.07 & 0.14 & 0.19 & 0.20 & 0.20 & 0.20 \\
\hline CAN & 0.00 & 0.10 & 0.27 & 0.43 & 0.50 & 0.50 & 0.50 \\
\hline CHE & 0.00 & 0.11 & 0.27 & 0.48 & 0.68 & 0.71 & 0.71 \\
\hline $\mathrm{CHL}$ & 0.00 & 0.27 & 0.61 & 0.89 & 1.00 & 1.00 & 1.00 \\
\hline CZE & 0.00 & 0.47 & 0.63 & 0.59 & 0.59 & 0.59 & 0.59 \\
\hline DEU & 0.24 & 0.36 & 0.53 & 0.70 & 0.80 & 0.81 & 0.81 \\
\hline DNK & 0.00 & 0.22 & 0.58 & 0.78 & 0.80 & 0.80 & 0.80 \\
\hline ESP & 0.00 & 0.30 & 0.59 & 0.75 & 0.78 & 0.78 & 0.78 \\
\hline EST & 0.00 & 0.45 & 0.83 & 0.98 & 1.00 & 1.00 & 1.00 \\
\hline FIN & 0.00 & 0.09 & 0.24 & 0.43 & 0.62 & 0.65 & 0.66 \\
\hline FRA & 0.57 & 0.60 & 0.66 & 0.72 & 0.78 & 0.79 & 0.79 \\
\hline GBR & 0.00 & 0.11 & 0.28 & 0.44 & 0.53 & 0.54 & 0.54 \\
\hline GRC & 0.00 & 0.73 & 0.97 & 0.86 & 0.85 & 0.85 & 0.85 \\
\hline HUN & 0.00 & 0.16 & 0.32 & 0.41 & 0.43 & 0.43 & 0.43 \\
\hline IDN & 0.00 & 0.07 & 0.14 & 0.19 & 0.20 & 0.20 & 0.20 \\
\hline IND & 0.00 & 0.86 & 1.00 & 1.00 & 1.00 & 1.00 & 1.00 \\
\hline $\mathbb{R L}$ & 0.00 & 0.06 & 0.18 & 0.29 & 0.32 & 0.32 & 0.32 \\
\hline ISL & 1.02 & 1.18 & 1.13 & 1.04 & 1.00 & 1.00 & 1.00 \\
\hline ISR & 0.00 & 0.12 & 0.28 & 0.45 & 0.55 & 0.55 & 0.55 \\
\hline ITA & 0.41 & 0.71 & 0.82 & 0.79 & 0.79 & 0.79 & 0.79 \\
\hline JPN & 0.78 & 0.79 & 0.81 & 0.84 & 0.92 & 0.97 & 0.99 \\
\hline KOR & 0.00 & 0.21 & 0.51 & 0.81 & 0.99 & 1.00 & 1.00 \\
\hline LUX & 0.00 & 0.14 & 0.51 & 0.92 & 1.00 & 1.00 & 1.00 \\
\hline MEX & 0.00 & 0.51 & 0.62 & 0.59 & 0.59 & 0.59 & 0.59 \\
\hline NLD & 0.00 & 0.07 & 0.18 & 0.33 & 0.47 & 0.49 & 0.49 \\
\hline NOR & 0.00 & 0.00 & 0.00 & 0.00 & 0.00 & 0.00 & 0.00 \\
\hline NZL & 0.98 & 1.03 & 0.76 & 0.70 & 0.70 & 0.70 & 0.70 \\
\hline POL & 0.72 & 0.80 & 0.64 & 0.66 & 0.66 & 0.66 & 0.66 \\
\hline PRT & 0.00 & 0.13 & 0.39 & 0.67 & 0.81 & 0.82 & 0.82 \\
\hline RUS & 0.00 & 0.25 & 0.45 & 0.52 & 0.53 & 0.53 & 0.53 \\
\hline SVK & 0.00 & 0.24 & 0.50 & 0.68 & 0.73 & 0.73 & 0.73 \\
\hline SVN & 0.24 & 0.33 & 0.43 & 0.50 & 0.51 & 0.51 & 0.51 \\
\hline SWE & 0.00 & 0.13 & 0.32 & 0.51 & 0.63 & 0.64 & 0.64 \\
\hline TUR & 0.27 & 0.52 & 0.60 & 0.57 & 0.58 & 0.58 & 0.58 \\
\hline USA & 1.07 & 1.40 & 1.33 & 1.05 & 1.00 & 1.00 & 1.00 \\
\hline ZAF & 0.00 & 0.11 & 0.25 & 0.39 & 0.45 & 0.45 & 0.45 \\
\hline
\end{tabular}


Table A.9. Estimated impulse-responses for import prices

\begin{tabular}{|c|c|c|c|c|c|c|c|}
\hline \multirow{3}{*}{\begin{tabular}{|c|} 
Response \\
Impulse \\
quarters \\
\end{tabular}} & \multicolumn{7}{|c|}{$\%$ change in PMGSX } \\
\hline & \multicolumn{7}{|c|}{$1 \%$ increase in PTDD } \\
\hline & 1 & 2 & 4 & 8 & 20 & 40 & 70 \\
\hline ARG & 0.62 & 0.42 & 0.17 & 0.08 & 0.07 & 0.07 & 0.07 \\
\hline AUS & 0.14 & 0.14 & 0.16 & 0.17 & 0.18 & 0.18 & 0.18 \\
\hline AUT & 0.17 & 0.21 & 0.27 & 0.34 & 0.40 & 0.41 & 0.41 \\
\hline BEL & 1.11 & 1.14 & 0.76 & 0.50 & 0.48 & 0.48 & 0.48 \\
\hline BRA & 0.40 & 0.19 & 0.10 & 0.09 & 0.09 & 0.09 & 0.09 \\
\hline CAN & 0.57 & 0.56 & 0.53 & 0.49 & 0.45 & 0.44 & 0.44 \\
\hline $\mathrm{CHE}$ & 0.65 & 0.50 & 0.37 & 0.32 & 0.32 & 0.32 & 0.32 \\
\hline $\mathrm{CHL}$ & 0.24 & 0.14 & 0.11 & 0.10 & 0.10 & 0.10 & 0.10 \\
\hline CZE & 0.47 & 0.37 & 0.34 & 0.34 & 0.34 & 0.34 & 0.34 \\
\hline DEU & 0.14 & 0.21 & 0.28 & 0.30 & 0.31 & 0.31 & 0.31 \\
\hline DNK & 0.31 & 0.39 & 0.46 & 0.50 & 0.51 & 0.51 & 0.51 \\
\hline ESP & 1.73 & 1.39 & 0.94 & 0.52 & 0.31 & 0.30 & 0.30 \\
\hline EST & 0.16 & 0.21 & 0.29 & 0.37 & 0.42 & 0.42 & 0.42 \\
\hline FIN & 0.17 & 0.28 & 0.43 & 0.58 & 0.66 & 0.67 & 0.67 \\
\hline FRA & 1.03 & 1.18 & 0.85 & 0.66 & 0.67 & 0.67 & 0.67 \\
\hline GBR & 0.57 & 0.48 & 0.37 & 0.28 & 0.25 & 0.25 & 0.25 \\
\hline GRC & 0.63 & 0.63 & 0.63 & 0.63 & 0.63 & 0.63 & 0.63 \\
\hline HUN & 0.24 & 0.34 & 0.37 & 0.37 & 0.37 & 0.37 & 0.37 \\
\hline IDN & 0.52 & 0.48 & 0.41 & 0.31 & 0.12 & 0.03 & 0.00 \\
\hline IND & 0.45 & 0.26 & 0.08 & 0.01 & 0.00 & 0.00 & 0.00 \\
\hline IRL & 0.17 & 0.18 & 0.19 & 0.21 & 0.22 & 0.22 & 0.22 \\
\hline ISL & 0.27 & 0.27 & 0.27 & 0.27 & 0.27 & 0.27 & 0.27 \\
\hline ISR & 0.16 & 0.09 & 0.07 & 0.03 & 0.00 & 0.00 & 0.00 \\
\hline ITA & 0.18 & 0.44 & 0.59 & 0.55 & 0.56 & 0.56 & 0.56 \\
\hline JPN & 1.05 & 0.97 & 0.88 & 0.81 & 0.79 & 0.79 & 0.79 \\
\hline KOR & 0.16 & 0.23 & 0.33 & 0.43 & 0.49 & 0.49 & 0.49 \\
\hline LUX & 0.17 & 0.26 & 0.39 & 0.54 & 0.66 & 0.67 & 0.67 \\
\hline MEX & 0.24 & 0.06 & 0.00 & 0.00 & 0.00 & 0.00 & 0.00 \\
\hline NLD & 0.14 & 0.24 & 0.38 & 0.52 & 0.60 & 0.61 & 0.61 \\
\hline NOR & 0.35 & 0.45 & 0.53 & 0.55 & 0.56 & 0.56 & 0.56 \\
\hline NZL & 0.14 & 0.18 & 0.24 & 0.30 & 0.33 & 0.34 & 0.34 \\
\hline $\mathrm{POL}$ & 0.49 & 0.38 & 0.37 & 0.36 & 0.35 & 0.35 & 0.35 \\
\hline PRT & 0.14 & 0.28 & 0.49 & 0.65 & 0.69 & 0.69 & 0.69 \\
\hline RUS & 0.16 & 0.17 & 0.25 & 0.34 & 0.41 & 0.42 & 0.42 \\
\hline SVK & 0.18 & 0.51 & 0.71 & 0.75 & 0.75 & 0.75 & 0.75 \\
\hline SVN & 0.36 & 0.31 & 0.28 & 0.27 & 0.27 & 0.27 & 0.27 \\
\hline SWE & 0.57 & 0.51 & 0.43 & 0.37 & 0.35 & 0.35 & 0.35 \\
\hline TUR & 0.45 & 0.43 & 0.29 & 0.24 & 0.24 & 0.24 & 0.24 \\
\hline USA & 1.55 & 1.57 & 1.15 & 0.82 & 0.75 & 0.75 & 0.75 \\
\hline ZAF & 0.90 & 0.85 & 0.77 & 0.65 & 0.49 & 0.44 & 0.44 \\
\hline
\end{tabular}

\begin{tabular}{|c|c|c|c|c|c|c|c|}
\hline Response & & & & ge in $F$ & & & \\
\hline \begin{tabular}{l|} 
Impulse \\
\end{tabular} & & & & ase in & $\mathrm{SHX}$ & & \\
\hline quarters & 1 & 2 & 4 & 8 & 20 & 40 & 70 \\
\hline ARG & 0.61 & 0.79 & 0.89 & 0.93 & 0.93 & 0.93 & 0.93 \\
\hline AUS & 0.64 & 0.68 & 0.73 & 0.79 & 0.82 & 0.82 & 0.82 \\
\hline AUT & 0.38 & 0.41 & 0.47 & 0.53 & 0.59 & 0.59 & 0.59 \\
\hline BEL & 0.49 & 0.60 & 0.57 & 0.52 & 0.52 & 0.52 & 0.52 \\
\hline BRA & 0.58 & 0.81 & 0.90 & 0.91 & 0.91 & 0.91 & 0.91 \\
\hline CAN & 0.20 & 0.25 & 0.32 & 0.42 & 0.53 & 0.56 & 0.56 \\
\hline CHE & 0.44 & 0.55 & 0.64 & 0.68 & 0.68 & 0.68 & 0.68 \\
\hline $\mathrm{CHL}$ & 0.67 & 0.83 & 0.89 & 0.90 & 0.90 & 0.90 & 0.90 \\
\hline CZE & 0.54 & 0.63 & 0.66 & 0.66 & 0.66 & 0.66 & 0.66 \\
\hline DEU & 0.76 & 0.97 & 0.92 & 0.74 & 0.69 & 0.69 & 0.69 \\
\hline DNK & 0.78 & 0.67 & 0.55 & 0.50 & 0.49 & 0.49 & 0.49 \\
\hline ESP & 0.32 & 0.41 & 0.53 & 0.64 & 0.70 & 0.70 & 0.70 \\
\hline EST & 0.25 & 0.32 & 0.42 & 0.52 & 0.58 & 0.58 & 0.58 \\
\hline FIN & 0.32 & 0.37 & 0.36 & 0.34 & 0.33 & 0.33 & 0.33 \\
\hline FRA & 0.31 & 0.41 & 0.37 & 0.33 & 0.33 & 0.33 & 0.33 \\
\hline GBR & 0.36 & 0.46 & 0.60 & 0.71 & 0.75 & 0.75 & 0.75 \\
\hline GRC & 0.23 & 0.29 & 0.34 & 0.36 & 0.37 & 0.37 & 0.37 \\
\hline HUN & 0.54 & 0.60 & 0.62 & 0.63 & 0.63 & 0.63 & 0.63 \\
\hline IDN & 0.48 & 0.51 & 0.58 & 0.69 & 0.88 & 0.97 & 1.00 \\
\hline IND & 0.52 & 0.72 & 0.91 & 0.99 & 1.00 & 1.00 & 1.00 \\
\hline IRL & 0.20 & 0.30 & 0.45 & 0.62 & 0.76 & 0.78 & 0.78 \\
\hline ISL & 0.77 & 0.75 & 0.73 & 0.73 & 0.73 & 0.73 & 0.73 \\
\hline ISR & 0.44 & 0.47 & 0.64 & 0.83 & 0.98 & 1.00 & 1.00 \\
\hline ITA & 0.33 & 0.48 & 0.47 & 0.44 & 0.44 & 0.44 & 0.44 \\
\hline JPN & 0.22 & 0.22 & 0.22 & 0.21 & 0.21 & 0.21 & 0.21 \\
\hline KOR & 0.19 & 0.25 & 0.35 & 0.45 & 0.50 & 0.51 & 0.51 \\
\hline LUX & 0.00 & 0.06 & 0.14 & 0.24 & 0.32 & 0.33 & 0.33 \\
\hline MEX & 0.73 & 0.94 & 1.00 & 1.00 & 1.00 & 1.00 & 1.00 \\
\hline NLD & 0.30 & 0.32 & 0.35 & 0.38 & 0.39 & 0.39 & 0.39 \\
\hline NOR & 0.49 & 0.47 & 0.45 & 0.44 & 0.44 & 0.44 & 0.44 \\
\hline NZL & 0.30 & 0.38 & 0.49 & 0.60 & 0.66 & 0.66 & 0.66 \\
\hline $\mathrm{POL}$ & 0.58 & 0.54 & 0.60 & 0.64 & 0.65 & 0.65 & 0.65 \\
\hline PRT & 0.32 & 0.39 & 0.37 & 0.32 & 0.31 & 0.31 & 0.31 \\
\hline RUS & 0.00 & 0.12 & 0.25 & 0.42 & 0.56 & 0.58 & 0.58 \\
\hline SVK & 0.00 & 0.14 & 0.23 & 0.25 & 0.25 & 0.25 & 0.25 \\
\hline SVN & 0.79 & 0.76 & 0.73 & 0.73 & 0.73 & 0.73 & 0.73 \\
\hline SWE & 0.41 & 0.48 & 0.56 & 0.63 & 0.65 & 0.65 & 0.65 \\
\hline TUR & 0.64 & 0.79 & 0.78 & 0.76 & 0.76 & 0.76 & 0.76 \\
\hline USA & 0.23 & 0.27 & 0.27 & 0.26 & 0.25 & 0.25 & 0.25 \\
\hline ZAF & 0.00 & 0.06 & 0.16 & 0.30 & 0.49 & 0.55 & 0.56 \\
\hline
\end{tabular}


Table A.10. Contribution of long-run trend to export volume growth

\begin{tabular}{|c|c|c|c|c|c|c|c|c|c|c|c|c|c|c|c|c|c|c|}
\hline & 1995 & 1996 & 1997 & 1998 & 1999 & 2000 & 2001 & 2002 & 2003 & 2004 & 2005 & 2006 & 2007 & 2008 & 2009 & 2010 & 2011 & 2012 \\
\hline ARG & 0.21 & 0.21 & 0.21 & 0.21 & -0.13 & -1.14 & -1.14 & -1.14 & -1.14 & -1.14 & -1.14 & -1.14 & -1.14 & -1.14 & -1.14 & -1.14 & -1.14 & -1.14 \\
\hline AUS & -0.79 & -0.79 & -0.79 & -0.79 & -0.79 & -0.79 & -0.79 & -0.79 & -0.79 & -0.79 & -0.79 & -0.79 & 1.51 & 1.51 & 1.51 & 1.51 & 1.51 & 1.51 \\
\hline AUT & -0.31 & -0.31 & -0.14 & 0.03 & 0.03 & 0.03 & 0.03 & 0.03 & 0.03 & 0.03 & 0.03 & 0.03 & 0.03 & -0.53 & -0.72 & -0.72 & -0.72 & -0.72 \\
\hline BEL & -0.22 & $\begin{array}{l}-0.22 \\
\end{array}$ & $\begin{array}{l}-0.22 \\
\end{array}$ & $\begin{array}{l}-0.22 \\
-0.22\end{array}$ & -0.22 & $\begin{array}{l}-0.22 \\
-0.22\end{array}$ & -0.22 & - 0.22 & $\begin{array}{l}-0.22 \\
-0.03\end{array}$ & -0.08 & -0.08 & -0.08 & -0.08 & -0.08 & -0.35 & $\begin{array}{l}-0.35 \\
-0.35\end{array}$ & $\begin{array}{l}-0.37 \\
-0.35\end{array}$ & $\begin{array}{l}-0.37 \\
-0.35\end{array}$ \\
\hline BRA & 2.02 & 2.02 & 2.02 & 2.02 & 2.02 & 2.02 & 7.93 & 9.90 & -2.24 & -2.24 & -2.24 & -2.24 & -2.24 & -2.24 & -2.24 & -2.24 & -2.24 & $\begin{array}{l}-2.24 \\
\end{array}$ \\
\hline CAN & $\begin{array}{l}-0.21 \\
-0.21\end{array}$ & $\begin{array}{l}-0.21 \\
\end{array}$ & $\begin{array}{l}-0.21 \\
-0.21\end{array}$ & $\begin{array}{l}-0.21 \\
-0.21\end{array}$ & $\begin{array}{l}-0.62 \\
-10\end{array}$ & $\begin{aligned}-1.04 \\
-1.04\end{aligned}$ & -1.04 & $\begin{array}{l}-1.004 \\
-1.04\end{array}$ & -1.04 & $\begin{array}{l}-1.04 \\
\end{array}$ & $\begin{array}{r}-1.04 \\
-1.04\end{array}$ & $\begin{array}{r}-1.04 \\
-1.04\end{array}$ & -1.04 & -1.04 & -1.04 & -1.04 & -1.04 & -1.04 \\
\hline CHE & -0.18 & -0.18 & -0.18 & -0.18 & -0.18 & -0.18 & -0.18 & -0.18 & -0.18 & -0.18 & $\begin{array}{l}-0.18 \\
-1.48\end{array}$ & -0.11 & 0.12 & 0.12 & 0.12 & 0.12 & 0.12 & 0.12 \\
\hline CHL & -0.83 & -0.83 & -0.83 & -0.83 & -0.83 & -0.83 & -0.83 & -0.83 & -0.82 & -0.82 & -0.82 & -0.82 & -1.37 & -3.03 & -3.03 & -3.03 & -3.03 & -3.03 \\
\hline CHN & 1.91 & 1.91 & 1.91 & 1.91 & 1.91 & 1.91 & 1.91 & 1.91 & 1.91 & 1.91 & 1.91 & 1.91 & 1.91 & 1.91 & 1.91 & 1.91 & 1.91 & 1.91 \\
\hline CZE & 0.58 & 0.58 & 0.67 & 0.75 & 0.75 & 0.75 & 0.75 & 0.75 & 0.75 & 0.75 & 0.75 & 0.75 & 0.75 & 0.75 & 0.75 & 0.75 & 0.75 & 0.75 \\
\hline DAE & 0.08 & 0.08 & 0.08 & 0.08 & 0.19 & 0.30 & 0.30 & 0.30 & 0.30 & 0.30 & 0.30 & 0.30 & 0.30 & 0.30 & 0.30 & 0.30 & 0.30 & 0.30 \\
\hline DEU & -0.98 & 0.36 & 0.36 & 0.36 & 0.36 & 0.36 & 0.36 & 0.36 & 0.36 & 0.36 & 0.36 & 0.36 & 0.36 & 0.36 & 0.36 & 0.36 & 0.36 & 0.36 \\
\hline DNK & -1.26 & -1.26 & -1.26 & -0.81 & 0.54 & 0.54 & 0.54 & 0.54 & -0.39 & -0.70 & -0.70 & -0.70 & -0.70 & -0.70 & -0.70 & -0.70 & -0.70 & -0.70 \\
\hline ESP & 0.07 & 0.07 & 0.07 & 0.07 & 0.07 & 0.07 & 0.07 & 0.07 & 0.07 & 0.03 & 0.00 & 0.00 & 0.00 & 0.00 & 0.00 & 0.00 & 0.00 & 0.00 \\
\hline EST & 0.72 & 0.72 & 0.72 & 0.72 & 0.72 & 0.72 & 0.72 & 0.72 & 0.72 & 0.72 & 0.72 & 0.54 & 0.35 & 0.35 & 0.35 & 0.35 & 0.35 & 0.35 \\
\hline FIN & 0.60 & 0.60 & 0.60 & 0.60 & 0.60 & 0.60 & 0.60 & -0.86 & -1.35 & -1.35 & -1.35 & -1.35 & -1.35 & - -1.35 & -1.35 & $\begin{array}{l}-1.35 \\
-1.35\end{array}$ & -1.35 & - -1.35 \\
\hline FRA & -0.28 & -0.28 & -0.28 & -0.28 & -0.28 & -0.28 & -0.28 & -0.91 & -1.54 & -1.54 & -1.54 & -1.54 & -1.54 & -1.54 & -1.54 & 0.09 & 0.63 & 0.63 \\
\hline GBR & -0.46 & -0.46 & -0.46 & -0.46 & -0.46 & -0.46 & -0.46 & -0.46 & -0.46 & -0.46 & -0.46 & -0.46 & -0.46 & -0.46 & -0.46 & -0.46 & -0.46 & -0.46 \\
\hline GRC & 0.57 & 0.40 & 0.23 & 0.23 & 0.23 & 0.23 & 0.23 & 0.23 & 0.23 & 0.23 & -1.17 & -1.17 & -1.17 & -1.17 & -1.17 & -1.17 & -1.17 & -1.17 \\
\hline HUN & 0.98 & 0.98 & 0.98 & 0.98 & 0.98 & 0.98 & 0.98 & 0.98 & 0.98 & 0.98 & 0.45 & 0.45 & 0.45 & 0.45 & 0.45 & 0.45 & 0.45 & 0.45 \\
\hline IDN & -0.24 & -0.24 & -0.24 & -0.24 & -0.24 & -0.24 & -0.24 & -0.24 & -0.24 & $\begin{array}{l}-0.24 \\
-0.24\end{array}$ & $\begin{array}{l}-.45 \\
-0.24\end{array}$ & $\begin{array}{l}-0.24 \\
-0.24\end{array}$ & $\begin{array}{l}-0.45 \\
-0.24\end{array}$ & $\begin{array}{l}-0.45 \\
-0.24\end{array}$ & 0.67 & $\begin{array}{l}0.458 \\
1.58\end{array}$ & $\begin{array}{l}1.58 \\
\end{array}$ & 1.58 \\
\hline IND & 0.99 & 0.99 & 2.72 & 3.30 & 3.30 & 3.30 & 3.30 & 3.30 & 3.30 & 3.30 & 3.30 & 3.30 & 3.30 & 3.30 & 3.30 & 3.30 & 3.30 & 3.30 \\
\hline IRL & 0.84 & 0.84 & 0.84 & 0.84 & 0.84 & 0.84 & 0.84 & -0.19 & -0.19 & -0.19 & -0.19 & -0.19 & -0.19 & -0.19 & -0.19 & -0.19 & -0.19 & -0.19 \\
\hline ISL & -1.02 & -1.02 & -1.02 & -0.42 & 0.17 & 0.17 & 0.17 & 0.17 & 0.17 & 0.17 & 0.17 & 0.17 & 0.17 & 0.17 & 0.17 & 0.17 & 0.17 & 0.17 \\
\hline ISR & 1.75 & 1.75 & 1.75 & 1.75 & 0.53 & -3.14 & -0.97 & -0.20 & -0.20 & -0.20 & -0.20 & -0.20 & -0.2 & -0.20 & -0.2 & -0.20 & -0.20 & -0.20 \\
\hline ITA & -0.69 & -0.69 & -0.69 & -0.69 & -0.69 & -0.69 & -0.69 & -0.69 & -0.69 & -0.69 & -0.6 & -0.69 & -0.6 & -0.69 & -0.6 & -0.69 & -0.69 & -0.69 \\
\hline JPN & -0.99 & -0.86 & -0.86 & -0.86 & -0.86 & -0.86 & -0.86 & -0.86 & -0.86 & -0.86 & -0.86 & -0.86 & -0.8 & -0.86 & -0.8 & -0.86 & -0.86 & -0.86 \\
\hline KOR & 0.79 & 0.10 & 0.10 & 0.10 & 0.10 & 0.10 & 0.10 & 0.10 & 0.10 & 0.10 & 0.10 & 0.1 & 0.1 & 0.10 & & 0.10 & 0.10 & 0.10 \\
\hline LUX & 0.22 & 0.22 & 0.30 & 0.55 & 0.55 & 0.55 & 0.4 & 0.21 & 0.2 & 0.2 & 0.2 & 0.2 & & 0.2 & & 0.2 & 0.2 & 0.21 \\
\hline MEX & 0.64 & 0.64 & 0.64 & 0.64 & 0.64 & 0.43 & -0.2 & -0.20 & -0.2 & -0.20 & -0.2 & -0.2 & -0.2 & -0.2 & -0.2 & -0.2 & -0.2 & -0.20 \\
\hline NLD & -0.06 & -0.06 & -0.06 & -0.06 & -0.0 & -0.06 & -0.0 & -0.06 & -0. & -0.06 & -0. & -0.0 & -0. & -0.0 & -0. & -0.0 & -0.0 & -0.06 \\
\hline NOR & -0.32 & -0.32 & -0.32 & -0.32 & -0.3 & -0.32 & -0.3 & -0.32 & & -0.3 & & -0.3 & -0. & -0.3 & -0. & -0.3 & -0.3 & -0.32 \\
\hline NZL & -0.30 & -0.30 & -0.3 & -0.41 & -0.4 & -0.41 & -0. & -0.4 & & & & & -0. & -0.4 & -0.4 & -0.4 & -0.4 & -0.41 \\
\hline OIL & -0.66 & -0.66 & -0.6 & -0.36 & -0.0 & -0.07 & & & & & & & & & & -0.0 & -0.0 & -0.07 \\
\hline POL & 1.23 & 1.23 & 0.8 & 0.8 & & 0.8 & & & & & & & & 0. & & 0. & & 0.81 \\
\hline PRT & -0.25 & -0.25 & -0.2 & -0.25 & & -0.2 & -0.2 & & & & & & & -0. & & -0.2 & -0.2 & -0.25 \\
\hline ROW & 0.06 & 0.06 & $0 . C$ & 0.06 & 0.0 & & & & & & & & & & & & & 0.12 \\
\hline RUS & -4.1 & -4.1 & -4.1 & -2.44 & 2.7 & 2.7 & & 2.7 & & & -0. & -0. & -0.2 & -0.2 & -0.2 & -0.2 & -0. & -0.29 \\
\hline SAU & -0.78 & -0.78 & -0 . & -0.7 & & -0.3 & & -0. & & & & & & & & & & -0.33 \\
\hline sVK & -1.47 & 0.33 & 0.8 & 1.43 & & 1.0 & & 1. & & & & & & $1 . C$ & & 1.0 & & 1.06 \\
\hline SVN & 0.41 & 0.41 & & 0.4 & & 0.4 & & & & & & & & -0. & & -0.4 & & -0.43 \\
\hline SWE & 0.73 & -0.13 & -0.1 & -0.13 & -0.1 & -0.13 & -0.1 & -0.1 & -0.1 & -0.1 & -0. & -0.1 & -0.1 & -0.13 & -0.13 & -0.13 & -0.13 & -0.13 \\
\hline TUR & 1.24 & 1.24 & 1.24 & 0.95 & 0.08 & 0.08 & 0.08 & 0.08 & 0.08 & & 0.08 & 0.0 & 0.08 & 0.08 & & 0.08 & 0.08 & 0.08 \\
\hline USA & -0.01 & -0.20 & -0.39 & -0.39 & -0.39 & -0.39 & -0.39 & -0.39 & -0.24 & -0.09 & -0.09 & -0.0 & -0.09 & -0.09 & -0.09 & -0.09 & -0.09 & -0.09 \\
\hline & -1.88 & -1.88 & -1.88 & -1.88 & -1.88 & -1.88 & -1.88 & -1.88 & -2.51 & -2.51 & -2.51 & -2.51 & -2.51 & -2.51 & -2.51 & -2.51 & -2.51 & \\
\hline
\end{tabular}

Note: Bold numbers denote statistical significance $<10 \%$.

Table A.11. Contribution of long-run trend to import volume growth

\begin{tabular}{|c|c|c|c|c|c|c|c|c|c|c|c|c|c|c|c|c|c|c|}
\hline & 1995 & 1996 & 1997 & 1998 & 1999 & 2000 & 2001 & 2002 & 2003 & 2004 & 2005 & 2006 & 2007 & 2008 & 2009 & 2010 & 2011 & 2012 \\
\hline ARG & .34 & -0.34 & 0.34 & -0.34 & -0.34 & -0.34 & -0.34 & -0.34 & -0.34 & -0.34 & -0.34 & -0.34 & -0.34 & -0.34 & -1.53 & -1.92 & -1.92 & -1.92 \\
\hline AUS & 60 & 0.60 & .60 & 0.60 & 0.60 & 0.60 & 0.31 & 0.01 & 0.01 & 0.01 & 0.01 & 0.01 & 0.01 & 0.01 & 0.01 & 0.01 & 0.01 & 0.01 \\
\hline AUT & -0.17 & -0.17 & -0.17 & -0.17 & -0.17 & 0.18 & & 0.29 & & 0.29 & 0.00 & -0.30 & -0.30 & & -0.30 & -0.30 & & -0.30 \\
\hline BEL & -0.23 & -0.23 & -0.23 & -0.23 & -0.23 & -0.23 & -0.23 & -0.23 & -0.23 & -0.23 & -0.23 & -0.23 & -0.23 & -0.23 & 0.16 & 0.16 & 0.16 & 0.16 \\
\hline BRA & -1.88 & -1.88 & -1.88 & -1.88 & -1.88 & -1.88 & -1.88 & -1.88 & -1.09 & -0.30 & -0.30 & -0.30 & -0.30 & -0.30 & -0.30 & -0.30 & -0.30 & -0.30 \\
\hline CAN & 0.00 & 0.00 & 0.00 & 0.00 & 0.00 & 0.00 & 0.00 & 0.00 & 0.00 & 0.00 & 0.00 & & 0.00 & 0.00 & 0.00 & 0.00 & 0.00 & 0.00 \\
\hline CHE & -0.05 & -0.05 & -0.05 & -0.05 & -0.05 & -0.05 & -0.05 & -0.05 & -0.05 & -0.05 & -0.05 & -0.05 & -0.05 & -0.05 & -0.05 & -0.05 & -0.05 & -0.05 \\
\hline CHL & 0.23 & 0.23 & 0.23 & 0.23 & 0.23 & 0.23 & 0.23 & 0.23 & 0.23 & 0.23 & 0.23 & 0.23 & 0.23 & 0.23 & -0.98 & -1.38 & -1.38 & -1.38 \\
\hline CHN & 1.02 & 1.02 & 1.02 & 1.02 & 1.02 & 1.02 & 1.02 & 1.02 & 1.02 & -0.02 & -1.06 & -1.06 & -1.06 & -1.06 & -1.36 & -1.46 & -1.46 & -1.46 \\
\hline CZE & 0.17 & 0.17 & 0.17 & 0.17 & 0.17 & 0.17 & 0.17 & 0.17 & 0.17 & 0.17 & 0.17 & & 0.17 & 0.31 & 0.75 & 0.75 & 0.75 & 0.75 \\
\hline DEU & -0.09 & -0.09 & -0.09 & -0.09 & -0.09 & -0.09 & -0.09 & -0.09 & 0.30 & 0.30 & 0.30 & 30 & 0.30 & 0.3 & 0.30 & 0.30 & 30 & 0.30 \\
\hline DNK & -0.34 & -0.12 & 0.09 & 0.09 & 0.09 & 0.09 & 0. & 0.09 & & 0.09 & 0.09 & 0.09 & 0.09 & 0.09 & 0.09 & 0.09 & .09 & 0.09 \\
\hline ESP & 1.40 & 1.40 & 1.40 & 1.40 & 1.40 & 0.01 & -0.45 & -0.45 & -0.45 & -0.45 & -0.45 & -0.45 & -0.45 & & 0.33 & 0.33 & 33 & 0.33 \\
\hline EST & -0.96 & -0.96 & -0.96 & -0.96 & -0.96 & -0.96 & -0.96 & -0.96 & -0.96 & -0.96 & -0.96 & -0.96 & -0.96 & 34 & 1.04 & 1.04 & 04 & 1.04 \\
\hline FIN & 0.29 & 0.29 & 0.29 & 0.29 & 0.29 & 0.29 & 0.2 & 0.29 & 0.1 & -0.29 & -0.29 & -0.29 & -0.29 & -0.29 & -0.29 & -0.29 & -0.29 & -0.29 \\
\hline FRA & 0.25 & 0.25 & 0.25 & 0. & 0.25 & 0.25 & -0.63 & -0.93 & -0.9 & -0.93 & -0.93 & -0.93 & -0.05 & & 0.25 & 0.25 & & 0.25 \\
\hline GBR & 0.02 & 0.02 & 0.02 & 0.02 & 0.02 & 0.02 & 0.02 & 0.02 & 0.02 & 0.02 & 0.02 & & 0.50 & & 50 & 0.50 & & 0.50 \\
\hline GRC & 1.31 & 1.31 & 1.31 & 1.31 & 0.91 & -0.29 & -0.29 & -0.29 & -0.29 & -0.29 & -0.29 & -0.29 & -0.29 & -0.29 & -0.29 & -0.29 & -0.29 & -0.29 \\
\hline HUN & 3.54 & 3.54 & 3.54 & 3.54 & 3.54 & 3.54 & 0.55 & 0.55 & 0.55 & 0.55 & 0.55 & 0.66 & 0.69 & 0.69 & 0.69 & 0.69 & 0.69 & 0.69 \\
\hline IDN & -0.84 & -0.84 & -0.84 & -0.84 & -0.71 & -0.71 & -0.71 & -0.71 & -0.71 & -0.71 & -0.71 & -0.71 & -0.71 & -0.71 & -0.71 & -0.71 & -0.71 & -0.71 \\
\hline IND & -1.00 & -1.00 & -1.00 & -1.00 & -1.00 & -1.00 & -1.00 & -1.00 & -1.00 & -1.00 & -1.00 & -1.00 & -1.00 & -1.00 & 1.36 & 1.36 & 1.36 & 1.36 \\
\hline IRL & 0.60 & 0.60 & 0.60 & 0.60 & 0.60 & 0.60 & 0.29 & -0.02 & -0.02 & -0.02 & -0.02 & -0.02 & -0.02 & -0.02 & -0.02 & -0.02 & -0.02 & -0.02 \\
\hline ISL & 0.25 & 0.25 & 0.25 & 0.25 & 0.25 & 0.25 & 0.25 & 0.25 & 0.25 & 0.25 & 0.25 & 0.25 & 0.25 & 0.25 & 0.25 & 0.25 & 0.25 & 0.25 \\
\hline ISR & .24 & -0.24 & -0.24 & -0.24 & -0.80 & -0.99 & -0.99 & -0.99 & -0.99 & -0.99 & -0.99 & -0.99 & -0.99 & -0.99 & -0.99 & -0.99 & -0.99 & -0.99 \\
\hline ITA & -0.05 & -0.05 & -0.05 & -0.05 & -0.05 & -0.05 & -0.05 & -0.03 & -0.0 & -0.02 & -0.02 & -0.0 & -0.02 & $-0 . c$ & -0.02 & -0.0 & -0. & -0.02 \\
\hline JPN & 0.11 & 0.1 & 0.11 & 0.1 & & 0.1 & & 0.1 & 0.1 & 0.1 & 0.11 & & 0.11 & 0.1 & 0.11 & 0.11 & 0.11 & 0.11 \\
\hline KOR & .87 & -0.87 & -0.87 & -0.60 & -0.60 & -0.60 & -0.60 & -0.60 & -0.60 & -0.60 & -0.60 & -0.60 & -0.60 & -0.60 & -0.60 & -0.60 & -0.60 & -0.60 \\
\hline LUX & -0.37 & -0.08 & -0.08 & -0.08 & -0.08 & -0.08 & -0.08 & -0.08 & -0.08 & -0.08 & -0.08 & -0.08 & -0.08 & -0.08 & -0.08 & -0.08 & -0.08 & -0.08 \\
\hline MEX & 1.23 & 0.54 & 0.30 & 0.36 & 0.30 & 0.3 & & 0.30 & 0.3 & 0.3 & 0.34 & & 0.35 & 0.3 & 0.35 & 0.3 & 0.35 & 0.35 \\
\hline NLD & -0.22 & -0.22 & -0.22 & -0.22 & -0.22 & -0.22 & -0.22 & -0.22 & -0.22 & -0.22 & -0.22 & -0.22 & 0.36 & 56 & 0.56 & 0.56 & 56 & 0.56 \\
\hline NOR & 0.31 & 0.31 & 0.31 & 0.31 & 0.31 & 0.31 & 0.31 & 0.27 & 0.26 & 0.26 & 0.26 & 0.26 & 0.26 & 0. & 0.26 & 0.26 & 26 & 0.26 \\
\hline NZL & -0.12 & -0.12 & -0.12 & -0.1 & -0. & -0.1 & -0. & -0.12 & -0.1 & -0.12 & -0.12 & -0. & -0.12 & -0. & -0.12 & -0.1 & & -0.12 \\
\hline POL & 0.27 & 0.27 & 0.27 & 0.2 & 0.27 & 0.27 & & 0.27 & -0.1 & -0.34 & -0.34 & -0.3 & -0.34 & -0.3 & -0.34 & -0.34 & -0.34 & -0.34 \\
\hline PRT & 0.34 & 0.34 & 0.34 & 0.3 & 0.34 & -0.24 & -0.24 & -0.24 & 0.28 & 0.28 & 0.28 & 28 & 0.28 & 0.28 & 0.28 & 0.28 & 28 & 0.28 \\
\hline RUS & -0.07 & -0.07 & -0.07 & 0.10 & 0.62 & 0.62 & 0.62 & 0.62 & 0.62 & 0.62 & 0.62 & & 0.62 & & 0.62 & 0.62 & 62 & 0.62 \\
\hline SVK & 0.38 & 0.38 & 0.38 & 0.38 & 0.38 & 0.38 & 0.5 & & 0.55 & & 0.55 & & 0.55 & & 0.55 & 0.55 & 55 & 0.55 \\
\hline SVN & -0.90 & -0.90 & -0.90 & -0.90 & -0.60 & 0.28 & & & & & 0.28 & & 0.28 & 0.28 & 0.28 & 0.28 & 28 & 0.28 \\
\hline SWE & 0.92 & 0.92 & 0.92 & 0.10 & -0.17 & -0.17 & -0.17 & -0.17 & -0.17 & -0.17 & -0.17 & -0.17 & -0.17 & -0.17 & -0.17 & -0.17 & -0.17 & -0.17 \\
\hline TUR & & & & & & & & & & & -0.58 & -0.8 & & -0.89 & -0.89 & -0.89 & -0.89 & -0.89 \\
\hline USA & 0.39 & 0.39 & 0.39 & & 0.39 & 0.39 & 0.26 & & & 0.14 & 0.14 & 0.14 & 0.14 & 0.14 & 0.14 & 0.14 & 0.14 & 0.14 \\
\hline ZAF & 0.48 & 0.48 & 0.48 & 0.48 & 0.48 & 0.48 & 0.48 & 0.48 & 0.48 & 0.48 & 0.48 & 0.48 & 0.48 & 0.48 & 0.71 & 0.93 & 0.93 & 0.93 \\
\hline
\end{tabular}

Note: Bold numbers denote statistical significance $<10 \%$. 
Table A.12. Contribution of long-run trend to export price growth

\begin{tabular}{|c|c|c|c|c|c|c|c|c|c|c|c|c|c|c|c|c|c|c|}
\hline & 1995 & 1996 & 1997 & 1998 & 1999 & 2000 & 2001 & 2002 & 2003 & 2004 & 2005 & 2006 & 2007 & 2008 & 2009 & 2010 & 2011 & 2012 \\
\hline ARG & 0.62 & 0.62 & 0.62 & 0.62 & 0.62 & 0.62 & 0.62 & 0.62 & -1.34 & -3.31 & -3.31 & -3.31 & -3.31 & -2.00 & 1.94 & 1.94 & 1.94 & 1.94 \\
\hline AUS & -1.73 & -1.73 & -1.73 & -1.73 & -1.73 & -1.73 & -1.73 & -0.84 & 1.84 & 1.84 & 1.84 & 1.84 & 1.84 & 1.84 & 1.84 & 1.84 & 1.84 & 1.84 \\
\hline AUT & -0.19 & -0.10 & -0.10 & -0.10 & -0.10 & -0.10 & -0.10 & 0.00 & 0.03 & -0.08 & -0.19 & -0.19 & -0.19 & -0.19 & -0.19 & -0.19 & -0.19 & -0.19 \\
\hline BEL & -0.30 & -0.26 & -0.26 & -0.26 & -0.26 & -0.26 & -0.26 & 0.06 & 0.16 & -0.11 & -0.39 & -0.39 & -0.39 & -0.39 & -0.39 & -0.39 & -0.39 & -0.39 \\
\hline BRA & 0.48 & 0.48 & 0.48 & 0.48 & 0.48 & 0.48 & 0.48 & 0.48 & 0.48 & 0.48 & 0.48 & 0.48 & 1.41 & 1.41 & 1.41 & 1.41 & $\begin{array}{l}1.41 \\
\text { S }\end{array}$ & 1.41 \\
\hline CAN & -0.15 & 0.07 & 0.07 & 0.07 & 0.07 & 0.07 & 0.07 & 0.07 & 0.07 & 0.07 & 0.07 & -0.71 & -0.97 & -0.97 & -0.97 & -0.97 & -0.97 & -0.97 \\
\hline CHE & -0.14 & -0.10 & -0.06 & -0.06 & -0.06 & -0.06 & -0.03 & -0.01 & -0.01 & -0.01 & -0.01 & -0.01 & -0.01 & -0.01 & -0.01 & -0.01 & -0.01 & -0.01 \\
\hline $\mathrm{CHL}$ & 0.95 & 0.95 & 0.95 & 0.95 & 0.95 & 0.95 & 0.95 & 0.95 & 0.95 & 6.62 & 6.62 & 4.37 & -2.37 & -2.37 & -2.37 & -2.37 & -2.37 & -2.37 \\
\hline CZE & -1.01 & -1.01 & -1.63 & -1.84 & -1.84 & -1.84 & -1.26 & 0.48 & 0.48 & -0.99 & -1.48 & -1.48 & -1.48 & -1.48 & -1.48 & -1.48 & -1.48 & -1.48 \\
\hline DEU & -0.29 & -0.18 & -0.18 & -0.18 & -0.18 & -0.18 & -0.18 & -0.18 & -0.18 & -0.18 & -0.18 & -0.18 & -0.18 & -0.18 & -0.18 & -0.18 & -0.18 & -0.18 \\
\hline DNK & -0.08 & -0.08 & -0.08 & -0.08 & -0.08 & -0.08 & -0.08 & -0.08 & -0.08 & -0.08 & -0.49 & -0.49 & -0.49 & -0.49 & -0.49 & -0.49 & -0.49 & -0.49 \\
\hline ESP & -0.22 & -0.22 & -0.22 & -0.22 & -0.22 & -0.22 & -0.22 & -0.22 & -0.22 & -0.22 & -0.22 & -0.22 & -0.35 & -0.74 & -0.74 & -0.74 & -0.74 & -0.74 \\
\hline EST & 0.02 & 0.02 & 0.02 & 0.02 & 0.02 & 0.02 & 0.02 & 0.02 & 0.02 & -0.84 & -1.13 & -1.13 & -1.13 & -1.13 & -1.13 & -1.13 & -1.13 & -1.13 \\
\hline FIN & -0.29 & -0.29 & -0.29 & -0.29 & $\begin{array}{l}-0.29 \\
\end{array}$ & -0.29 & -0.24 & -0.24 & -0.24 & -0.24 & -0.24 & -0.24 & -0.24 & -0.24 & -0.24 & -0.24 & -0.24 & -0.24 \\
\hline FRA & -0.27 & -0.27 & -0.27 & -0.27 & -0.27 & -0.27 & -0.27 & -0.34 & -0.32 & -0.21 & -0.21 & -0.21 & -0.21 & -0.21 & -0.21 & -0.21 & -0.21 & -0.21 \\
\hline GBR & -0.20 & -0.20 & -0.20 & -0.20 & -0.20 & -0.20 & -0.20 & -0.20 & -0.20 & -0.20 & -0.23 & -0.26 & -0.26 & -0.26 & -0.26 & -0.26 & -0.26 & -0.26 \\
\hline GRC & -1.25 & -1.25 & -1.25 & -1.25 & -1.25 & 0.02 & 3.81 & 3.81 & 3.81 & -0.94 & -0.94 & -0.94 & -0.94 & -0.94 & -0.94 & -0.94 & -0.94 & -0.94 \\
\hline HUN & -0.76 & -0.76 & -0.76 & -0.76 & -0.76 & -0.76 & -0.76 & -0.76 & -0.76 & -0.76 & -1.06 & -1.06 & -1.06 & -1.06 & -1.06 & -1.06 & -1.06 & -1.06 \\
\hline IDN & 1.63 & 1.63 & 1.63 & 1.63 & -2.05 & -2.05 & -2.05 & -2.05 & -2.05 & -2.05 & -2.05 & -2.05 & -2.05 & -2.05 & -2.05 & -2.05 & -2.05 & -2.05 \\
\hline IND & -1.33 & -1.33 & -1.33 & -1.33 & -1.33 & -1.33 & -1.33 & -1.33 & -1.33 & -1.33 & -1.33 & -1.33 & -1.33 & -0.86 & -0.40 & -0.40 & -0.40 & -0.40 \\
\hline IRL & -0.01 & -0.01 & -0.01 & -0.01 & -0.01 & -0.01 & -0.01 & -0.01 & -0.01 & -0.01 & -0.01 & -0.01 & -0.01 & -0.01 & -0.01 & $\begin{array}{l}-0.01 \\
\end{array}$ & -0.01 & -0.01 \\
\hline ISL & 0.87 & 0.87 & 0.87 & 0.28 & 0.08 & 0.08 & 0.08 & 0.08 & 0.08 & 0.08 & 0.08 & 0.08 & 0.08 & 0.08 & 0.08 & 0.08 & 0.08 & 0.08 \\
\hline ISR & 0.26 & 0.26 & 0.26 & 0.26 & 0.26 & 0.26 & 0.26 & 0.26 & -0.03 & -0.31 & -0.31 & -0.31 & -0.31 & -0.31 & -0.31 & -0.31 & -0.31 & -0.31 \\
\hline ITA & -0.34 & -0.34 & -0.34 & -0.34 & -0.34 & -0.34 & -0.34 & 0.15 & 0.15 & -0.22 & -0.59 & -0.59 & -0.59 & -0.59 & -0.59 & -0.59 & -0.59 & -0.59 \\
\hline JPN & -0.16 & -0.01 & -0.01 & -0.01 & -0.01 & -0.01 & -0.01 & -0.01 & -0.01 & -0.01 & -0.01 & -0.01 & -0.01 & -0.01 & -0.01 & -0.01 & -0.01 & -0.01 \\
\hline KOR & -1.19 & -1.19 & -1.19 & -1.19 & -1.19 & -1.19 & -1.19 & -1.19 & -1.19 & -1.19 & -1.19 & -1.19 & -1.19 & -0.25 & 0.70 & 0.70 & 0.70 & 0.70 \\
\hline LUX & 0.14 & 0.14 & 0.14 & 0.14 & 0.14 & 0.14 & 0.14 & 0.14 & 0.14 & 0.14 & 0.14 & 0.14 & 0.14 & 0.14 & 0.14 & 0.14 & 0.14 & 0.14 \\
\hline MEX & 1.69 & -2.37 & -2.37 & -2.37 & -2.37 & -2.37 & -2.37 & -2.44 & -2.47 & -2.47 & -2.47 & -2.47 & -2.47 & -2.47 & -2.47 & -2.47 & -2.47 & -2.47 \\
\hline NLD & -0.36 & -0.36 & -0.36 & -0.36 & -0.36 & -0.36 & -0.36 & 0.02 & 0.39 & -0.24 & -0.24 & -0.24 & -0.24 & -0.24 & -0.24 & -0.24 & -0.24 & -0.24 \\
\hline NOR & -0.11 & -0.11 & -0.11 & -0.11 & 2.70 & 2.70 & 2.70 & 2.70 & 2.70 & 2.70 & 2.70 & 2.70 & 1.14 & -3.52 & -3.52 & -3.52 & -3.52 & -3.52 \\
\hline NZI & -0.38 & -0.38 & -1.39 & -2.39 & -0.76 & -0.21 & -0.21 & -0.21 & -0.21 & -0.21 & -0.21 & -0.21 & -0.21 & -0.21 & -0.21 & -0.21 & -0.21 & -0.21 \\
\hline $\mathrm{POL}$ & -3.22 & -0.37 & 0.57 & 0.57 & 0.57 & 0.57 & 0.57 & 0.57 & 0.57 & 0.57 & 0.57 & 0.57 & 0.57 & 0.57 & 0.57 & 0.57 & 0.57 & 0.57 \\
\hline PRT & -0.23 & -0.23 & -0.23 & -0.23 & -0.23 & -0.23 & -0.23 & -0.23 & -0.23 & -0.23 & -0.23 & -0.23 & -0.23 & -0.23 & -0.23 & -0.23 & -0.23 & -0.23 \\
\hline RUS & -1.26 & -1.26 & -1.26 & -1.26 & -1.26 & -1.18 & -1.18 & -1.18 & -1.18 & -1.18 & -1.18 & -1.18 & -1.18 & -1.18 & -1.18 & -1.18 & -1.18 & -1.18 \\
\hline SVK & -0.45 & -0.45 & -0.53 & -0.76 & -0.76 & -0.34 & -0.19 & -0.19 & -0.19 & -0.19 & -0.19 & -0.19 & -0.18 & -0.15 & -0.15 & -0.15 & -0.15 & -0.15 \\
\hline SVN & -0.36 & -0.36 & -0.36 & -0.36 & -0.36 & -0.36 & -0.36 & 0.27 & 0.60 & -0.28 & -0.28 & -0.28 & -0.28 & -0.28 & -0.28 & -0.28 & -0.28 & -0.28 \\
\hline SWE & -0.44 & -0.44 & -0.44 & -0.44 & -0.44 & -0.44 & -0.44 & -0.27 & -0.22 & -0.22 & -0.22 & -0.22 & -0.22 & -0.22 & -0.22 & -0.22 & -0.22 & -0.22 \\
\hline TUR & 0.23 & 0.23 & 0.23 & 0.23 & 0.23 & 0.23 & 0.23 & 0.23 & 0.23 & 0.23 & 0.23 & 0.23 & 0.23 & 0.23 & 0.23 & 0.23 & 0.23 & 0.23 \\
\hline USA & -0.50 & -0.50 & -0.30 & -0.30 & -0.30 & -0.30 & -0.30 & -0.30 & -0.30 & -0.30 & -0.30 & -0.30 & -0.30 & -0.30 & -0.30 & -0.30 & -0.30 & -0.30 \\
\hline $\mathrm{ZAF}$ & -1.07 & -0.61 & 0.78 & 0.78 & 0.78 & 0.78 & 0.78 & 0.78 & 0.78 & 0.78 & 0.78 & 0.78 & 0.78 & 0.78 & 0.78 & 0.78 & 0.78 & 0.78 \\
\hline
\end{tabular}

Note: Bold numbers denote statistical significance $<10 \%$.

Table A.13. Contribution of long-run trend to import price growth

\begin{tabular}{|c|c|c|c|c|c|c|c|c|c|c|c|c|c|c|c|c|c|c|}
\hline & 1995 & 1996 & 1997 & 1998 & 1999 & 2000 & 2001 & 2002 & 2003 & 2004 & 2005 & 2006 & 2007 & 2008 & 2009 & 2010 & 2011 & 2012 \\
\hline ARG & -0.22 & -0.22 & -0.22 & -0.22 & -0.22 & -0.22 & -0.22 & -0.64 & $\begin{array}{l}-1.06 \\
\end{array}$ & $\begin{array}{l}-1.06 \\
\end{array}$ & -1.06 & -1.06 & -1.06 & -1.06 & -1.06 & -1.06 & -1.06 & -1.06 \\
\hline AUS & -0.26 & -0.26 & -0.64 & -0.64 & -0.64 & -0.64 & -0.32 & 0.00 & 0.00 & 0.00 & 0.00 & 0.00 & 0.00 & 0.00 & 0.00 & 0.00 & 0.00 & 0.00 \\
\hline AUT & -0.09 & -0.09 & -0.09 & -0.09 & -0.09 & -0.09 & -0.09 & -0.09 & -0.09 & -0.09 & -0.09 & -0.09 & -0.09 & -0.09 & -0.09 & -0.09 & -0.09 & -0.09 \\
\hline BEL & -0.28 & -0.28 & -0.28 & -0.28 & -0.28 & -0.28 & -0.28 & -0.02 & 0.25 & 0.25 & -0.26 & -0.43 & -0.43 & -0.43 & -0.43 & -0.43 & -0.43 & -0.43 \\
\hline BRA & 1.94 & 1.94 & 1.94 & 1.94 & 2.03 & 2.11 & 0.99 & 0.62 & 0.62 & 0.62 & 0.62 & 0.62 & 0.62 & 0.62 & 0.62 & 0.62 & 0.62 & 0.62 \\
\hline CAN & 0.03 & 0.03 & 0.03 & 0.03 & -0.02 & -0.17 & -0.17 & -0.17 & -0.17 & -0.17 & -0.17 & -0.17 & -0.17 & -0.17 & -0.17 & -0.17 & -0.17 & -0.17 \\
\hline CHE & -0.22 & -0.82 & -1.09 & -0.06 & -0.06 & -0.06 & -0.06 & -0.06 & -0.06 & -0.06 & -0.06 & -0.06 & 0.11 & 0.62 & 0.62 & 0.62 & 0.62 & 0.62 \\
\hline $\mathrm{CHL}$ & -1.90 & -1.90 & -1.90 & -1.90 & -1.90 & -1.90 & -1.90 & -1.90 & -1.90 & -1.90 & -1.16 & -1.16 & -1.16 & -1.16 & -1.16 & -1.16 & -1.16 & -1.16 \\
\hline $\mathrm{CHN}$ & 0.27 & 0.27 & 0.14 & -0.26 & -0.26 & -0.26 & -0.26 & -0.26 & -0.26 & -0.26 & -0.26 & -0.26 & -0.26 & -0.26 & -0.26 & -0.26 & -0.26 & -0.26 \\
\hline CZE & -0.97 & -0.97 & -0.97 & -0.97 & -0.97 & -0.97 & -0.17 & -0.17 & -0.17 & -0.17 & -0.17 & -0.17 & -0.17 & -0.17 & -1.28 & -1.28 & -1.28 & -1.28 \\
\hline DEU & -0.30 & -0.30 & -0.30 & -0.30 & -0.30 & -0.30 & -0.30 & -0.30 & -0.30 & -0.30 & -0.30 & -0.30 & -0.30 & -0.30 & -0.30 & -0.30 & -0.30 & -0.30 \\
\hline DNK & -0.38 & -0.38 & -0.38 & -0.38 & -0.38 & -0.38 & -0.38 & -0.30 & -0.05 & -0.05 & -0.05 & -0.05 & -0.05 & -0.89 & -1.17 & -1.17 & -1.17 & -1.17 \\
\hline ESP & -0.35 & -0.35 & -0.35 & -0.35 & -0.35 & -0.35 & -0.35 & 0.06 & 0.06 & -0.07 & -0.21 & -0.21 & -0.21 & -0.21 & -0.21 & -0.21 & -0.21 & -0.21 \\
\hline EST & 0.11 & 0.11 & 0.11 & 0.04 & -0.19 & -0.19 & -0.19 & -0.19 & -0.19 & -0.19 & -0.19 & -0.19 & -0.19 & -0.19 & -0.19 & -0.19 & -0.19 & -0.19 \\
\hline FIN & -0.40 & -0.40 & -0.40 & -0.40 & -0.40 & -0.40 & -0.40 & -0.40 & -0.40 & -0.40 & -0.40 & -0.40 & -0.40 & -0.40 & -0.40 & -0.40 & -0.40 & -0.40 \\
\hline FRA & -0.83 & -0.83 & -0.83 & -0.83 & -0.83 & -0.83 & -0.83 & -0.79 & -0.77 & -0.77 & -0.77 & -0.77 & -0.77 & -0.77 & -0.77 & -0.77 & -0.77 & -0.77 \\
\hline GBR & -0.20 & -0.20 & -0.20 & -0.20 & -0.20 & -0.20 & -0.20 & -0.20 & -0.20 & -0.20 & -0.20 & -0.20 & -0.20 & -1.87 & -0.30 & -0.30 & -0.30 & -0.30 \\
\hline GRC & -0.91 & -0.91 & -0.91 & -0.91 & -0.19 & 0.52 & 0.52 & 0.52 & 0.52 & 0.52 & -0.83 & -0.83 & -0.83 & -0.83 & -0.83 & -0.83 & -0.83 & -0.83 \\
\hline HUN & -1.63 & -1.63 & -1.63 & -1.63 & -1.63 & -1.63 & -1.63 & -0.32 & -0.32 & -1.91 & -2.44 & -2.44 & -2.44 & -2.44 & -2.44 & -2.44 & -2.44 & -2.44 \\
\hline IDN & -0.01 & -0.01 & -0.01 & -0.01 & 0.26 & 0.26 & 0.26 & 0.26 & 0.26 & 0.26 & 0.26 & 0.26 & 0.26 & 0.26 & 0.26 & 0.26 & 0.26 & 0.26 \\
\hline IND & -0.61 & -0.61 & -0.61 & -0.61 & -0.61 & -0.61 & -0.61 & -0.61 & -0.61 & -0.52 & -0.28 & -0.28 & -0.28 & -0.28 & -0.28 & -0.28 & -0.28 & -0.28 \\
\hline IRL & -0.08 & -0.08 & -0.08 & -0.08 & -0.08 & -0.08 & 0.12 & 0.19 & 0.19 & 0.19 & 0.19 & 0.19 & 0.19 & 0.19 & 0.19 & 0.19 & 0.19 & 0.19 \\
\hline ISL & 0.72 & 0.72 & 0.72 & 0.72 & 0.72 & 0.72 & 0.72 & 0.72 & 0.72 & 0.72 & 0.72 & 0.72 & 0.72 & 0.07 & 0.41 & 1.40 & 1.40 & 1.40 \\
\hline ISR & 0.30 & 0.30 & 0.30 & 0.30 & 0.30 & -0.26 & -0.26 & -0.26 & -0.26 & -0.26 & -0.26 & -0.26 & -0.26 & -0.26 & -0.26 & -0.26 & -0.26 & -0.26 \\
\hline ITA & -0.19 & -0.19 & -0.19 & -0.19 & -0.03 & 0.13 & 0.13 & 0.13 & 0.13 & 0.13 & 0.13 & 0.13 & -1.44 & -1.44 & -1.44 & -1.44 & -1.44 & -1.44 \\
\hline JPN & -0.86 & -0.23 & -0.23 & -0.23 & -0.23 & -0.23 & -0.23 & -0.23 & -0.23 & -0.23 & -0.23 & -0.23 & -0.23 & -0.23 & -0.23 & -0.23 & -0.23 & -0.23 \\
\hline KOR & -0.60 & -0.60 & -0.60 & -0.60 & -0.60 & -0.60 & -0.60 & -0.60 & -0.60 & -0.60 & -0.60 & -0.60 & -0.60 & -0.60 & -0.60 & -0.60 & -0.60 & -0.60 \\
\hline LUX & 0.23 & 0.25 & 0.25 & 0.25 & 0.25 & 0.25 & 0.05 & 0.05 & 0.05 & 0.05 & 0.05 & 0.05 & 0.05 & 0.05 & 0.05 & 0.05 & 0.05 & 0.05 \\
\hline MEX & 0.81 & 0.81 & 0.81 & 0.81 & 0.81 & 0.81 & 0.81 & -1.72 & -1.72 & -1.72 & -1.72 & -1.72 & -1.72 & -0.16 & 1.40 & 1.40 & 1.40 & 1.40 \\
\hline NLD & -0.33 & -0.78 & -0.78 & -0.78 & -0.78 & -0.78 & -0.78 & -0.08 & 0.15 & -0.18 & -0.51 & -0.51 & -0.51 & -0.51 & -0.51 & -0.51 & -0.51 & -0.51 \\
\hline NOR & -0.43 & -0.43 & -0.43 & -0.43 & -0.43 & -0.43 & -0.43 & -0.35 & -0.26 & -0.26 & -0.26 & -0.26 & -0.26 & -0.26 & -0.26 & -0.26 & -0.26 & -0.26 \\
\hline NZL & 0.08 & 0.08 & 0.08 & 0.08 & 0.08 & -0.29 & -0.29 & -0.29 & -0.29 & -0.29 & -0.29 & -0.29 & -0.29 & -0.29 & -0.29 & -0.29 & -0.29 & -0.29 \\
\hline POL & -1.20 & -1.20 & 0.90 & 0.90 & 0.90 & 0.90 & 0.90 & 0.90 & 0.90 & 0.90 & 0.90 & -0.18 & -0.18 & -0.18 & -0.18 & -0.18 & -0.18 & -0.18 \\
\hline PRT & -0.46 & -0.46 & -0.46 & -0.46 & -0.46 & -0.46 & -0.46 & -0.46 & -0.46 & -0.46 & -0.46 & -0.46 & -0.46 & -0.46 & -0.46 & -0.46 & -0.46 & -0.46 \\
\hline RUS & -1.19 & -1.19 & -1.19 & -1.19 & -1.19 & -1.19 & -1.19 & -1.19 & -1.19 & -1.19 & -0.65 & -0.47 & -0.47 & -0.47 & -0.47 & -0.47 & -0.47 & -0.47 \\
\hline SVK & 0.00 & 0.00 & 0.00 & -1.17 & -4.68 & -0.24 & -0.24 & -0.24 & -0.24 & -0.24 & -0.24 & -0.24 & -0.24 & -0.24 & -0.24 & -0.24 & -0.24 & -0.24 \\
\hline SVN & -1.14 & -1.14 & -1.14 & -1.14 & -1.14 & -1.14 & -1.14 & 1.17 & 0.67 & -0.82 & -0.82 & -0.82 & -0.82 & -0.82 & -0.82 & -0.82 & -0.82 & -0.82 \\
\hline SWE & -0.30 & -0.30 & -0.30 & -0.30 & -0.30 & -0.30 & -0.30 & -0.30 & -0.30 & -0.30 & -0.30 & -0.30 & -0.30 & -0.30 & -0.30 & -0.30 & -0.30 & -0.30 \\
\hline TUR & -0.14 & -0.14 & -0.14 & -0.14 & -0.14 & -0.14 & -0.14 & -0.14 & 0.51 & 1.17 & 1.17 & 1.17 & 1.17 & 1.17 & 1.17 & 1.17 & 1.17 & 1.17 \\
\hline USA & -0.59 & -0.59 & -0.59 & -0.59 & -0.59 & -0.39 & -0.39 & -0.39 & -0.39 & -0.39 & -0.39 & -0.39 & -0.39 & -0.39 & -0.39 & -0.39 & -0.39 & -0.39 \\
\hline ZAF & 0.07 & 0.07 & 0.07 & 0.07 & 0.21 & 0.35 & 0.35 & 0.35 & 0.35 & 0.35 & -0.05 & -0.18 & -0.18 & -0.18 & -0.18 & -0.18 & $\begin{array}{l}-0.18 \\
\end{array}$ & -0.18 \\
\hline
\end{tabular}

Note: Bold numbers denote statistical significance at $<10 \%$. 
Table A.14. Root mean squared forecasting error (2009Q1-2012Q4)

Export volume equations

\begin{tabular}{|c|c|c|c|c|c|c|}
\hline & \multicolumn{3}{|c|}{4 periods ahead } & \multicolumn{3}{|c|}{8 periods ahead } \\
\hline Country & Flat trend & Linear trend & $\begin{array}{c}\text { Flattening } \\
\text { trend }\end{array}$ & Flat trend & Linear trend & $\begin{array}{l}\text { Flattening } \\
\text { trend }\end{array}$ \\
\hline ARG & 0.0403 & 0.0406 & 0.0404 & 0.0455 & 0.0437 & 0.0454 \\
\hline AUS & 0.0286 & 0.0271 & 0.0274 & 0.0295 & 0.0298 & 0.0293 \\
\hline AUT & 0.0107 & 0.0073 & 0.0080 & 0.0061 & 0.0067 & 0.0051 \\
\hline BEL & 0.0123 & 0.0109 & 0.0113 & 0.0130 & 0.0105 & 0.0120 \\
\hline BRA & 0.0234 & 0.0235 & 0.0233 & 0.0300 & 0.0299 & 0.0300 \\
\hline CAN & 0.0167 & 0.0174 & 0.0169 & 0.0155 & 0.0168 & 0.0155 \\
\hline $\mathrm{CHE}$ & 0.0081 & 0.0084 & 0.0083 & 0.0080 & 0.0077 & 0.0078 \\
\hline $\mathrm{CHL}$ & 0.0409 & 0.0400 & 0.0401 & 0.0710 & 0.0715 & 0.0710 \\
\hline $\mathrm{CHN}$ & 0.0257 & 0.0279 & 0.0263 & 0.0335 & 0.0369 & 0.0333 \\
\hline CZE & 0.0179 & 0.0193 & 0.0187 & 0.0200 & 0.0212 & 0.0200 \\
\hline DAE & 0.0178 & 0.0178 & 0.0178 & 0.0157 & 0.0159 & 0.0157 \\
\hline DEU & 0.0100 & 0.0097 & 0.0098 & 0.0128 & 0.0125 & 0.0128 \\
\hline DNK & 0.0122 & 0.0103 & 0.0109 & 0.0123 & 0.0102 & 0.0118 \\
\hline ESP & 0.0104 & 0.0104 & 0.0104 & 0.0206 & 0.0206 & 0.0206 \\
\hline EST & 0.0341 & 0.0334 & 0.0336 & 0.0425 & 0.0415 & 0.0422 \\
\hline FIN & 0.0847 & 0.0844 & 0.0845 & 0.0378 & 0.0353 & 0.0372 \\
\hline FRA & 0.0081 & 0.0087 & 0.0078 & 0.0074 & 0.0083 & 0.0075 \\
\hline GBR & 0.0179 & 0.0176 & 0.0177 & 0.0183 & 0.0178 & 0.0180 \\
\hline GRC & 0.0597 & 0.0588 & 0.0590 & 0.0566 & 0.0572 & 0.0565 \\
\hline HUN & 0.0114 & 0.0119 & 0.0117 & 0.0107 & 0.0128 & 0.0112 \\
\hline IDN & 0.0465 & 0.0451 & 0.0453 & 0.0440 & 0.0471 & 0.0457 \\
\hline IND & 0.0322 & 0.0259 & 0.0273 & 0.0329 & 0.0341 & 0.0324 \\
\hline $\mathrm{IRL}$ & 0.0151 & 0.0154 & 0.0153 & 0.0127 & 0.0123 & 0.0125 \\
\hline ISL & 0.0463 & 0.0464 & 0.0463 & 0.0497 & 0.0497 & 0.0497 \\
\hline ISR & 0.0190 & 0.0189 & 0.0189 & 0.0239 & 0.0234 & 0.0238 \\
\hline ITA & 0.0112 & 0.0107 & 0.0107 & 0.0101 & 0.0115 & 0.0101 \\
\hline JPN & 0.0407 & 0.0403 & 0.0403 & 0.0454 & 0.0424 & 0.0444 \\
\hline KOR & 0.0265 & 0.0266 & 0.0266 & 0.0209 & 0.0210 & 0.0209 \\
\hline LUX & 0.0203 & 0.0206 & 0.0205 & 0.0257 & 0.0263 & 0.0259 \\
\hline MEX & 0.0128 & 0.0128 & 0.0128 & 0.0189 & 0.0192 & 0.0190 \\
\hline NLD & 0.0118 & 0.0118 & 0.0118 & 0.0158 & 0.0158 & 0.0158 \\
\hline NOR & 0.0253 & 0.0250 & 0.0251 & 0.0272 & 0.0276 & 0.0273 \\
\hline NZL & 0.0125 & 0.0127 & 0.0126 & 0.0202 & 0.0204 & 0.0201 \\
\hline OIL & 0.0122 & 0.0119 & 0.0120 & 0.0172 & 0.0160 & 0.0168 \\
\hline $\mathrm{POL}$ & 0.0261 & 0.0290 & 0.0278 & 0.0224 & 0.0228 & 0.0222 \\
\hline PRT & 0.0211 & 0.0214 & 0.0213 & 0.0183 & 0.0190 & 0.0185 \\
\hline RUS & 0.0164 & 0.0162 & 0.0163 & 0.0127 & 0.0126 & 0.0127 \\
\hline SAU & 0.0148 & 0.0108 & 0.0119 & 0.0043 & 0.0095 & 0.0056 \\
\hline SVK & 0.0322 & 0.0329 & 0.0325 & 0.0266 & 0.0230 & 0.0252 \\
\hline SVN & 0.0144 & 0.0140 & 0.0141 & 0.0112 & 0.0108 & 0.0109 \\
\hline SWE & 0.0181 & 0.0179 & 0.0180 & 0.0193 & 0.0192 & 0.0192 \\
\hline TUR & 0.0442 & 0.0442 & 0.0442 & 0.0398 & 0.0394 & 0.0397 \\
\hline USA & 0.0093 & 0.0093 & 0.0093 & 0.0070 & 0.0068 & 0.0069 \\
\hline ZAF & 0.0153 & 0.0134 & 0.0137 & 0.0174 & 0.0135 & 0.0171 \\
\hline
\end{tabular}


Table A.15. Root mean squared forecasting error (2009Q1-2012Q4)

Import volume equations

\begin{tabular}{|c|c|c|c|c|c|c|}
\hline & \multicolumn{3}{|c|}{4 periods ahead } & \multicolumn{3}{|c|}{8 periods ahead } \\
\hline Country & Flat trend & Linear trend & $\begin{array}{l}\text { Flattening } \\
\text { trend }\end{array}$ & Flat trend & Linear trend & $\begin{array}{c}\text { Flattening } \\
\text { trend }\end{array}$ \\
\hline AUS & 0.0151 & 0.0151 & 0.0151 & 0.0131 & 0.0131 & 0.0131 \\
\hline AUT & 0.0070 & 0.0063 & 0.0064 & 0.0054 & 0.0074 & 0.0057 \\
\hline BEL & 0.0090 & 0.0090 & 0.0089 & 0.0097 & 0.0096 & 0.0097 \\
\hline BRA & 0.0212 & 0.0214 & 0.0213 & 0.0343 & 0.0344 & 0.0343 \\
\hline CAN & 0.0128 & 0.0128 & 0.0128 & 0.0116 & 0.0116 & 0.0116 \\
\hline $\mathrm{CHE}$ & 0.0105 & 0.0103 & 0.0104 & 0.0076 & 0.0076 & 0.0076 \\
\hline $\mathrm{CHL}$ & 0.0248 & 0.0253 & 0.0250 & 0.0244 & 0.0239 & 0.0244 \\
\hline $\mathrm{CHN}$ & 0.0299 & 0.0231 & 0.0259 & 0.0252 & 0.0239 & 0.0243 \\
\hline CZE & 0.0167 & 0.0181 & 0.0174 & 0.0237 & 0.0233 & 0.0234 \\
\hline DEU & 0.0113 & 0.0117 & 0.0115 & 0.0097 & 0.0099 & 0.0097 \\
\hline DNK & 0.0118 & 0.0118 & 0.0118 & 0.0123 & 0.0120 & 0.0122 \\
\hline ESP & 0.0126 & 0.0120 & 0.0122 & 0.0148 & 0.0144 & 0.0148 \\
\hline EST & 0.0316 & 0.0307 & 0.0308 & 0.0351 & 0.0357 & 0.0350 \\
\hline FIN & 0.0270 & 0.0273 & 0.0272 & 0.0154 & 0.0153 & 0.0153 \\
\hline FRA & 0.0097 & 0.0087 & 0.0091 & 0.0053 & 0.0046 & 0.0051 \\
\hline GBR & 0.0170 & 0.0165 & 0.0166 & 0.0151 & 0.0152 & 0.0151 \\
\hline GRC & 0.0287 & 0.0290 & 0.0289 & 0.0224 & 0.0229 & 0.0225 \\
\hline HUN & 0.0142 & 0.0136 & 0.0138 & 0.0186 & 0.0195 & 0.0187 \\
\hline IDN & 0.0596 & 0.0590 & 0.0592 & 0.0776 & 0.0775 & 0.0775 \\
\hline IRL & 0.0134 & 0.0133 & 0.0133 & 0.0167 & 0.0167 & 0.0167 \\
\hline ISL & 0.0233 & 0.0235 & 0.0234 & 0.0358 & 0.0359 & 0.0358 \\
\hline ISR & 0.0208 & 0.0200 & 0.0201 & 0.0249 & 0.0232 & 0.0245 \\
\hline ITA & 0.0150 & 0.0151 & 0.0151 & 0.0161 & 0.0162 & 0.0161 \\
\hline JPN & 0.0147 & 0.0148 & 0.0148 & 0.0156 & 0.0155 & 0.0156 \\
\hline KOR & 0.0189 & 0.0188 & 0.0187 & 0.0185 & 0.0174 & 0.0178 \\
\hline LUX & 0.0236 & 0.0237 & 0.0237 & 0.0156 & 0.0156 & 0.0156 \\
\hline MEX & 0.0165 & 0.0159 & 0.0160 & 0.0142 & 0.0146 & 0.0142 \\
\hline NLD & 0.0113 & 0.0107 & 0.0107 & 0.0115 & 0.0098 & 0.0109 \\
\hline NOR & 0.0309 & 0.0307 & 0.0308 & 0.0280 & 0.0281 & 0.0280 \\
\hline NZL & 0.0175 & 0.0178 & 0.0177 & 0.0208 & 0.0207 & 0.0208 \\
\hline POL & 0.0117 & 0.0120 & 0.0118 & 0.0118 & 0.0102 & 0.0113 \\
\hline PRT & 0.0220 & 0.0222 & 0.0221 & 0.0164 & 0.0159 & 0.0162 \\
\hline SVK & 0.0377 & 0.0378 & 0.0377 & 0.0323 & 0.0313 & 0.0321 \\
\hline SVN & 0.0180 & 0.0178 & 0.0178 & 0.0184 & 0.0181 & 0.0184 \\
\hline SWE & 0.0088 & 0.0090 & 0.0089 & 0.0069 & 0.0068 & 0.0069 \\
\hline TUR & 0.0327 & 0.0331 & 0.0328 & 0.0406 & 0.0419 & 0.0408 \\
\hline USA & 0.0119 & 0.0118 & 0.0119 & 0.0115 & 0.0118 & 0.0115 \\
\hline ZAF & 0.0199 & 0.0259 & 0.0184 & 0.0189 & 0.0194 & 0.0189 \\
\hline
\end{tabular}


Table A.16. Root mean squared forecasting error (2009Q1-2012Q4)

Export price equations

\begin{tabular}{|c|c|c|c|c|c|c|}
\hline & \multicolumn{3}{|c|}{4 periods ahead } & \multicolumn{3}{|c|}{8 periods ahead } \\
\hline Country & Flat trend & Linear trend & $\begin{array}{c}\text { Flattening } \\
\text { trend }\end{array}$ & Flat trend & Linear trend & $\begin{array}{c}\text { Flattening } \\
\text { trend }\end{array}$ \\
\hline AUS & 0.0789 & 0.0753 & 0.0765 & 0.0803 & 0.0851 & 0.0806 \\
\hline AUT & 0.0034 & 0.0034 & 0.0033 & 0.0055 & 0.0051 & 0.0053 \\
\hline BEL & 0.0070 & 0.0051 & 0.0055 & 0.0099 & 0.0072 & 0.0091 \\
\hline BRA & 0.0808 & 0.0777 & 0.0788 & 0.0893 & 0.0887 & 0.0891 \\
\hline CAN & 0.0260 & 0.0271 & 0.0265 & 0.0214 & 0.0216 & 0.0209 \\
\hline $\mathrm{CHE}$ & 0.0059 & 0.0058 & 0.0058 & 0.0067 & 0.0067 & 0.0067 \\
\hline $\mathrm{CHL}$ & 0.0816 & 0.0853 & 0.0837 & 0.0762 & 0.0748 & 0.0754 \\
\hline CZE & 0.0091 & 0.0089 & 0.0087 & 0.0072 & 0.0081 & 0.0072 \\
\hline DEU & 0.0053 & 0.0052 & 0.0052 & 0.0047 & 0.0039 & 0.0044 \\
\hline DNK & 0.0149 & 0.0143 & 0.0144 & 0.0181 & 0.0169 & 0.0177 \\
\hline ESP & 0.0124 & 0.0117 & 0.0118 & 0.0134 & 0.0138 & 0.0133 \\
\hline EST & 0.0341 & 0.0332 & 0.0334 & 0.0280 & 0.0277 & 0.0278 \\
\hline FIN & 0.0266 & 0.0264 & 0.0265 & 0.0180 & 0.0172 & 0.0177 \\
\hline FRA & 0.0066 & 0.0062 & 0.0063 & 0.0090 & 0.0089 & 0.0089 \\
\hline GBR & 0.0079 & 0.0078 & 0.0078 & 0.0074 & 0.0070 & 0.0072 \\
\hline GRC & 0.0193 & 0.0189 & 0.0191 & 0.0180 & 0.0180 & 0.0180 \\
\hline HUN & 0.0145 & 0.0143 & 0.0141 & 0.0179 & 0.0139 & 0.0170 \\
\hline IDN & 0.0746 & 0.0732 & 0.0735 & 0.1054 & 0.1021 & 0.1046 \\
\hline $\mathrm{IRL}$ & 0.0136 & 0.0137 & 0.0137 & 0.0102 & 0.0102 & 0.0102 \\
\hline ISL & 0.0381 & 0.0380 & 0.0381 & 0.0417 & 0.0421 & 0.0418 \\
\hline ISR & 0.0229 & 0.0232 & 0.0231 & 0.0242 & 0.0249 & 0.0244 \\
\hline ITA & 0.0075 & 0.0068 & 0.0070 & 0.0072 & 0.0071 & 0.0071 \\
\hline JPN & 0.0100 & 0.0100 & 0.0100 & 0.0131 & 0.0131 & 0.0131 \\
\hline KOR & 0.0277 & 0.0258 & 0.0264 & 0.0269 & 0.0290 & 0.0274 \\
\hline LUX & 0.0080 & 0.0081 & 0.0080 & 0.0099 & 0.0099 & 0.0098 \\
\hline MEX & 0.0351 & 0.0345 & 0.0346 & 0.0467 & 0.0457 & 0.0467 \\
\hline NLD & 0.0322 & 0.0320 & 0.0321 & 0.0335 & 0.0330 & 0.0333 \\
\hline NOR & 0.0663 & 0.0657 & 0.0655 & 0.0559 & 0.0570 & 0.0558 \\
\hline NZL & 0.0530 & 0.0529 & 0.0529 & 0.0419 & 0.0422 & 0.0419 \\
\hline $\mathrm{POL}$ & 0.0335 & 0.0335 & 0.0335 & 0.0254 & 0.0256 & 0.0254 \\
\hline PRT & 0.0092 & 0.0096 & 0.0094 & 0.0055 & 0.0074 & 0.0060 \\
\hline SVK & 0.0129 & 0.0131 & 0.0130 & 0.0132 & 0.0131 & 0.0132 \\
\hline SVN & 0.0058 & 0.0057 & 0.0057 & 0.0076 & 0.0076 & 0.0075 \\
\hline SWE & 0.0180 & 0.0177 & 0.0178 & 0.0167 & 0.0157 & 0.0164 \\
\hline TUR & 0.0267 & 0.0266 & 0.0266 & 0.0274 & 0.0272 & 0.0274 \\
\hline USA & 0.0088 & 0.0086 & 0.0086 & 0.0081 & 0.0079 & 0.0079 \\
\hline ZAF & 0.0272 & 0.0245 & 0.0254 & 0.0210 & 0.0231 & 0.0214 \\
\hline
\end{tabular}


Table A.17. Root mean squared forecasting error (2009Q1-2012Q4)

Import price equations

\begin{tabular}{|c|c|c|c|c|c|c|}
\hline & \multicolumn{3}{|c|}{4 periods ahead } & \multicolumn{3}{|c|}{8 periods ahead } \\
\hline Country & Flat trend & Linear trend & $\begin{array}{l}\text { Flattening } \\
\text { trend }\end{array}$ & Flat trend & Linear trend & $\begin{array}{l}\text { Flattening } \\
\text { trend }\end{array}$ \\
\hline AUS & 0.0122 & 0.0122 & 0.0122 & 0.0101 & 0.0101 & 0.0101 \\
\hline AUT & 0.0076 & 0.0076 & 0.0076 & 0.0090 & 0.0090 & 0.0090 \\
\hline BEL & 0.0113 & 0.0100 & 0.0104 & 0.0081 & 0.0066 & 0.0077 \\
\hline BRA & 0.0373 & 0.0372 & 0.0372 & 0.0321 & 0.0320 & 0.0321 \\
\hline CAN & 0.0151 & 0.0149 & 0.0149 & 0.0153 & 0.0149 & 0.0151 \\
\hline $\mathrm{CHE}$ & 0.0106 & 0.0101 & 0.0102 & 0.0097 & 0.0099 & 0.0097 \\
\hline $\mathrm{CHL}$ & 0.0194 & 0.0195 & 0.0194 & 0.0364 & 0.0360 & 0.0364 \\
\hline CZE & 0.0107 & 0.0103 & 0.0105 & 0.0089 & 0.0086 & 0.0088 \\
\hline DEU & 0.0145 & 0.0135 & 0.0138 & 0.0105 & 0.0097 & 0.0102 \\
\hline DNK & 0.0192 & 0.0179 & 0.0181 & 0.0148 & 0.0160 & 0.0148 \\
\hline ESP & 0.0111 & 0.0107 & 0.0108 & 0.0179 & 0.0182 & 0.0180 \\
\hline EST & 0.0195 & 0.0195 & 0.0195 & 0.0218 & 0.0221 & 0.0219 \\
\hline FIN & 0.0190 & 0.0195 & 0.0193 & 0.0191 & 0.0190 & 0.0189 \\
\hline FRA & 0.0120 & 0.0100 & 0.0105 & 0.0087 & 0.0090 & 0.0086 \\
\hline GBR & 0.0107 & 0.0106 & 0.0101 & 0.0106 & 0.0107 & 0.0102 \\
\hline GRC & 0.0365 & 0.0355 & 0.0358 & 0.0351 & 0.0346 & 0.0350 \\
\hline HUN & 0.0167 & 0.0136 & 0.0145 & 0.0166 & 0.0119 & 0.0163 \\
\hline IDN & 0.0569 & 0.0568 & 0.0568 & 0.0529 & 0.0529 & 0.0528 \\
\hline IRL & 0.0089 & 0.0084 & 0.0086 & 0.0091 & 0.0090 & 0.0090 \\
\hline ISL & 0.0223 & 0.0219 & 0.0213 & 0.0250 & 0.0241 & 0.0251 \\
\hline ISR & 0.0133 & 0.0139 & 0.0137 & 0.0140 & 0.0149 & 0.0142 \\
\hline ITA & 0.0102 & 0.0082 & 0.0085 & 0.0095 & 0.0096 & 0.0094 \\
\hline JPN & 0.0349 & 0.0350 & 0.0350 & 0.0389 & 0.0388 & 0.0388 \\
\hline KOR & 0.0361 & 0.0367 & 0.0364 & 0.0400 & 0.0389 & 0.0395 \\
\hline LUX & 0.0214 & 0.0214 & 0.0214 & 0.0187 & 0.0188 & 0.0187 \\
\hline MEX & 0.0267 & 0.0274 & 0.0270 & 0.0260 & 0.0269 & 0.0260 \\
\hline NLD & 0.0337 & 0.0331 & 0.0333 & 0.0338 & 0.0330 & 0.0335 \\
\hline NOR & 0.0147 & 0.0142 & 0.0144 & 0.0118 & 0.0118 & 0.0118 \\
\hline NZL & 0.0141 & 0.0134 & 0.0136 & 0.0128 & 0.0139 & 0.0130 \\
\hline POL & 0.0282 & 0.0281 & 0.0282 & 0.0242 & 0.0241 & 0.0241 \\
\hline PRT & 0.0115 & 0.0091 & 0.0098 & 0.0123 & 0.0108 & 0.0116 \\
\hline SVK & 0.0160 & 0.0160 & 0.0160 & 0.0188 & 0.0185 & 0.0188 \\
\hline SVN & 0.0230 & 0.0221 & 0.0224 & 0.0179 & 0.0175 & 0.0178 \\
\hline SWE & 0.0203 & 0.0197 & 0.0199 & 0.0214 & 0.0203 & 0.0211 \\
\hline TUR & 0.0453 & 0.0435 & 0.0441 & 0.0476 & 0.0453 & 0.0473 \\
\hline USA & 0.0089 & 0.0083 & 0.0084 & 0.0105 & 0.0101 & 0.0103 \\
\hline ZAF & 0.0235 & 0.0238 & 0.0237 & 0.0254 & 0.0256 & 0.0254 \\
\hline
\end{tabular}


Table A.18 Constraints on relative marginal import propensities

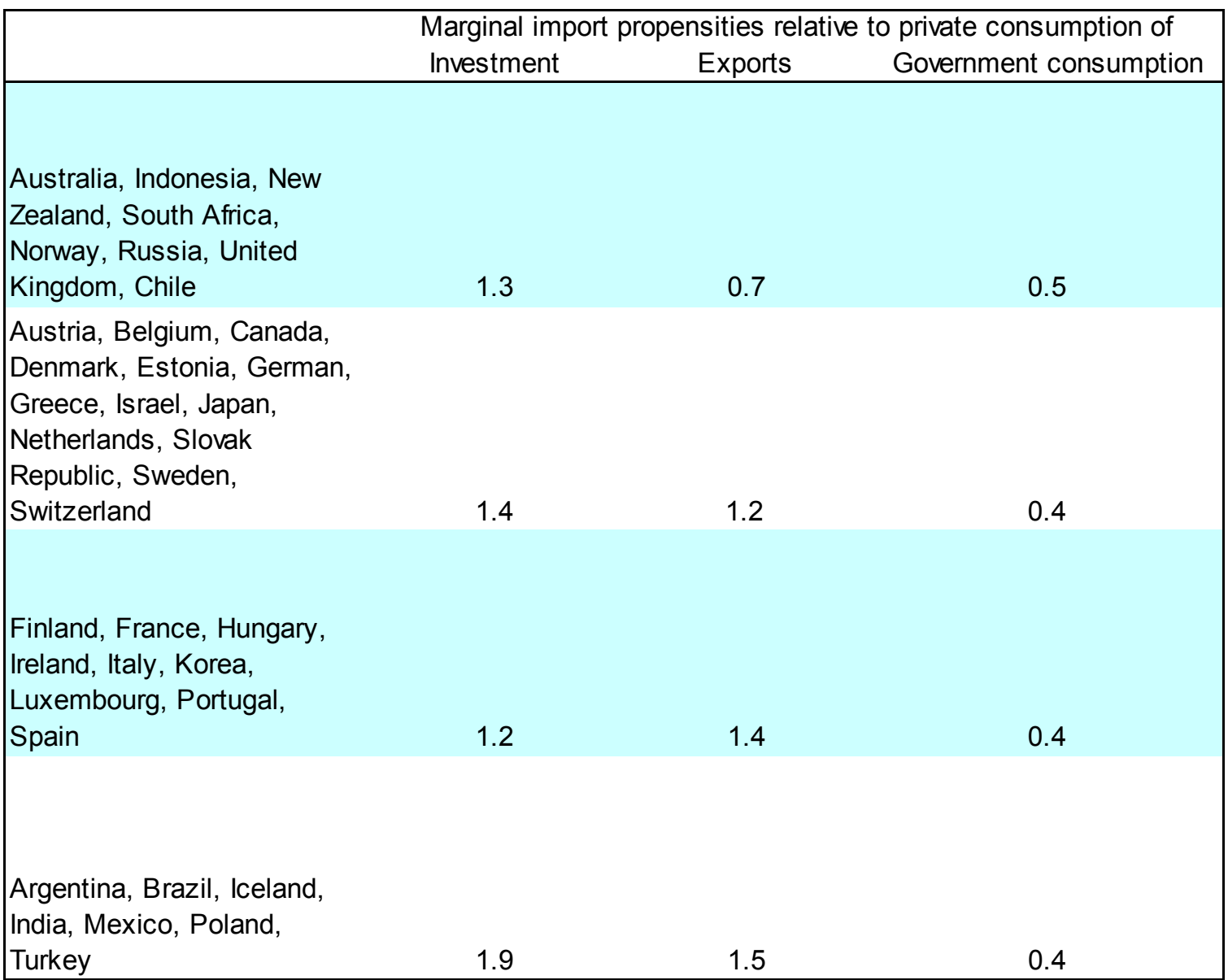




\section{WORKING PAPERS}

The full series of Economics Department Working Papers can be consulted at www.oecd.org/eco/workingpapers

1128. What explains the volume and composition of trade? Industrial evidence from a panel of countries (June 2014) by Åsa Johansson, Przemyslaw Kowalski, Eduardo Olaberría and Dario Pellegrino

1127. Do resources flow to patenting firms: cross-country evidence from firm level data (June 2014) by Dan Andrews, Chiara Criscuolo and Carlo Menon

1126. Macroprudential policy tools in Norway: Strengthening financial system resilience (June 2014) by Yosuke Jin, Patrick Lenain and Paul O’Brien

1125. Strengthening competition in Poland

(June 2014) by Balász Égert and Antoine Goujard

1124. Making the labour market work better in Poland (June 2014) by Hervé Boulhol

1123. Enhancing competition and the business environment in Hungary (June 2014) by Alvaro Pina

1122. Tackling labour mismatches and promoting mobility in Hungary (June 2014) by Stéphane Sorbe

1121. Local public finances and municipal reform in Finland (June 2014) by Christophe André and Clara Garcia

1120. The economic consequences of ageing: the case of Finland (June 2014) by Christine de la Maisonneuve, Christophe André, Clara Garcia and Vincent Koen

1119. Making the most of skills in Denmark

(June 2014) by Stéphanie Jamet and Vincent Koen

1118. Trade specialisation and policies to foster competition and innovation in Denmark (June 2014) by Müge Adalet McGowan

1117. Policies for making the Chilean labour market more inclusive (June 2014) by Aida Caldera Sanchez

1116. Spillover effects from exiting highly expansionary monetary policies

(May 2014) by Łukasz Rawdanowicz, Romain Bouis, Jérôme Brezillon, Ane Kathrine Christensen and Kei-Ichiro Inaba

1115. Economic policies and microeconomic stability: A literature review and some empirics (April 2014) by Paula Garda and Volker Ziemann

1114. How to improve Israel's health-care system

(April 2014) by Philip Hemmings 
1113. How to improve taxes and transfers in Israel

(April 2014) by Philip Hemmings

1112. New evidence on the determinants of industrial specialisation

(April 2014) by Asa Johansson and Eduardo Olaberria

1111. Economic growth from the household perspective: GDP and income distribution developments across OECD countries

(April 2014) by Orsetta Causa, Sonia Araujo, Agnès Cavaciuti, Nicolas Ruiz and Zuzana Smidova

1110. Would a growth slowdown in emerging markets spill over to high-income countries? A quantitative assessment

(April 2014) By Patrice Ollivaud, Elena Rusticelli and Cyrille Schwellnus

1109. Short-term indicator models for quarterly GDP growth in the BRIICS: A small-scale bridge model approach

(April 2014) by Thomas Chalaux and Cyrille Schwellnus

1108. The prudential regulation of financial institutions: why regulatory responses to the crisis might not prove sufficient

(March 2014) by William R. White

1107. OECD forecasts during and after the financial crisis: a post mortem

(March 2014) by Nigel Pain, Christine Lewis, Thai-Thanh Dang, Yosuke Jin and

Pete Richardson

1106. Fairly sharing the social impact of the crisis in Greece

(January 2014) by Vassiliki Koutsogeorgopoulou, Manos Matsaganis, Chrysa Leventi and Jan-David Schneider

1105. Dividing the pie in Brazil: income distribution, social policies and the new middle class

(January 2014) by Jens M. Arnold and João Jalles

1104. New indicators of competition law and policy in 2013 for OECD and non-OECD countries (December 2013) by Enrico Alemani, Caroline Klein, Isabell Koske, Cristiana Vitale and Isabelle Wanner

1103. The effect of government debt, external debt and their interaction on OECD interest rates (December 2013) by David Turner and Francesca Spinelli

1102. The state of the banking sector in Europe

(December 2013) by Dirk Schoenmaker and Toon Peek 